\title{
Predictions of Participant Satisfaction and Loyalty at the West Virginia University Outdoor Education Center
}

\author{
Connor R. James
}

Follow this and additional works at: https://researchrepository.wvu.edu/etd

\section{Recommended Citation}

James, Connor R., "Predictions of Participant Satisfaction and Loyalty at the West Virginia University Outdoor Education Center" (2017). Graduate Theses, Dissertations, and Problem Reports. 7093. https://researchrepository.wvu.edu/etd/7093

This Thesis is protected by copyright and/or related rights. It has been brought to you by the The Research Repository @ WVU with permission from the rights-holder(s). You are free to use this Thesis in any way that is permitted by the copyright and related rights legislation that applies to your use. For other uses you must obtain permission from the rights-holder(s) directly, unless additional rights are indicated by a Creative Commons license in the record and/ or on the work itself. This Thesis has been accepted for inclusion in WVU Graduate Theses, Dissertations, and Problem Reports collection by an authorized administrator of The Research Repository @ WVU. For more information, please contact researchrepository@mail.wvu.edu. 


\title{
Predictions of Participant Satisfaction and Loyalty at the West Virginia University Outdoor Education Center
}

\author{
Connor R. James
}

A Thesis Submitted to the

Davis College of Agriculture, Natural Resources and Design

At West Virginia University

In partial fulfillment of the Requirements for the Degree of

Master of Science in

Recreation, Parks, and Tourism Resources

Dr. Jinyang Deng, Ph.D., Chair

Dr. Steve Selin, Ph.D.

Coy Belknap, M.S.

Frank DeMarco M.B.A.

Department of Recreation, Parks and Tourism Resources

$$
\text { Morgantown, West Virginia }
$$

2017

Keywords: Adventure Recreation, WVU, Outdoor Education, Expectation, Motivation, Satisfaction, Loyalty, Structural Equation Model

Copyright 2017 Connor James 


\section{Abstract \\ Predictions of Participant Satisfaction and Loyalty at the West Virginia University Outdoor Education Center}

\section{Connor James}

The overall purpose of this study is to develop a sense of understanding into the general visitors of the West Virginia University Outdoor Education Center (WVU OEC). The WVU OEC is a portion of the university outdoor program Adventure West Virginia. This site has a zip line canopy tour, multiple high rope challenge course elements and a variety of ground based teambuilding elements.

Participants at the WVU OEC were surveyed in the summer of 2016 to understand their expectations, motivations, satisfactions, and loyalty associated with their one-day experience. These participants have participated in a zip line canopy tour and/or on-site challenge course program.

To develop a quantitative instrument for this study, a qualitative pre-survey conducted in the spring of 2016 was used to derive items measuring expectations and motivations specific to the canopy tour and on-site challenge course programs. These items on expectations and motivations were then used, along with other measures, for the full survey conducted in the summer of the year. Data are analyzed in SPSS 22 and AMOS 24. A factor analysis was conducted to obtain latent variables for each measure. These latent variables were then used for further analyses including t-tests (to compare similarities and differences between three pairs of groups-first time users vs. repeaters, males vs. females, and program contacts and program participants), Analysis of Variance (ANOVA, to compare similarities and differences between three activities participatedcanopy tour only, challenge course only, and both), and Structural Equation Modelling (SEM, to examine the relationship between expectations, motivations, satisfaction, and loyalty).

It is found that no significant differences exist between first timers and repeaters and between males and females in their expectations, motivations, satisfaction, and loyalty. However, program contacts are found to be more positive than general participants on some items. In addition, significant differences are also found between participants doing canopy tour, challenge course, or both in the same day.

Findings from the SEM model include a significant positive relationship between expectations and motivations. Itemized satisfaction (i.e., satisfaction with activities and satisfaction with instructors) has a positive significant relationship to overall satisfaction, which in turn has a significant positive relationship to loyalty. Finally, motivations also have a positive significant indication of overall satisfaction while expectations do not.

The findings of this study will be used to help the WVU OEC market to their audience appropriately. They will also serve as a guide for future organizational decisions. 


\section{ACKNOWLEDGEMENTS}

I would like to thank Dr. Jinyang Deng, Dr. Steve Selin, CJ and Frank for allowing me to pick their brains and take up their office time. The one-on-one time gave me better insight toward the overall project and gave me time to get to know everyone on a personal basis. I would like to give emphasis to the amount of time and guidance I received from Dr. Deng. Many of the ideas and time spent analyzing the data came from you either directly or indirectly from your work.

I would also like to acknowledge my team at the Outdoor Education Center, who helped me come up with ideas and assisted with the data collection. Specifically, the other OEC Graduate Assistants Marissa and Bob, who I had to share a computer with for two years. Also, CJ and Shannon who helped me throughout the process and encouraged me to finish the task and allowed me to have an extraordinarily flexible work schedule.

The third set of people I would like to acknowledge are all the Recreation, Parks, and Tourism Resources students at WVU who have helped me through the past six years of school. From all the random walks of life that I have come upon, these have been the most influential toward my everyday life at WVU.

The final group of people I would like to acknowledge is my family. I have always appreciated all that you have contributed toward me. My brother Jason being the first one to go to college, eight years before me, showed me to keep going even when things don't go your way. And finally, my parents, Frank and Michele James. I realize that six straight years in college wasn't your first choice, but you encouraged me the entire way through, and for this, I could not have more gratitude. 


\section{Table of Contents}

ACKNOWLEDGEMENTS .............................................................................................. III

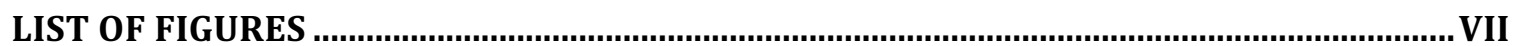

LIST OF TABLES $\ldots$

CHAPTER 1: INTRODUCTION

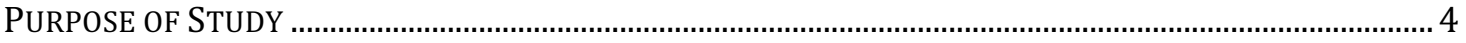

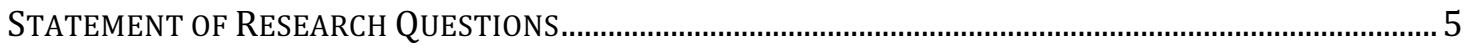

CHAPTER 2: LITERATURE REVIEW

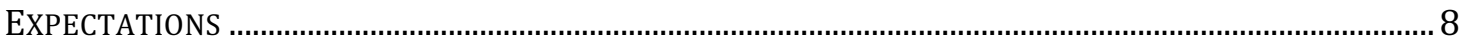

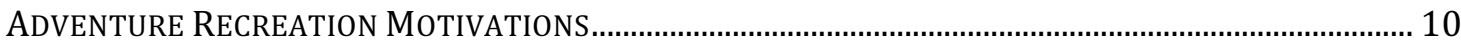

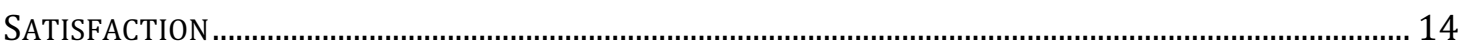

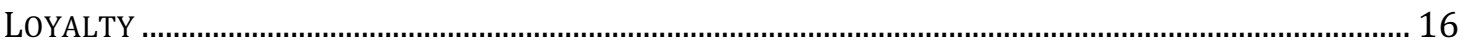

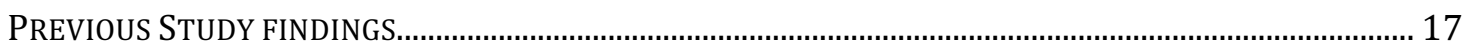

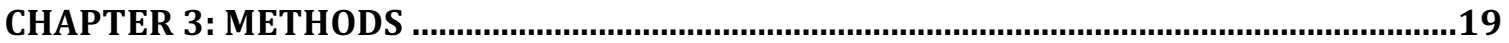

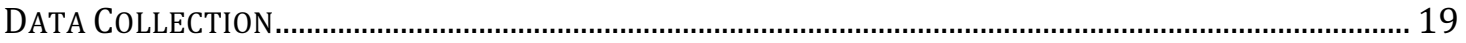

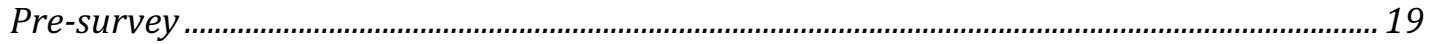

Survey

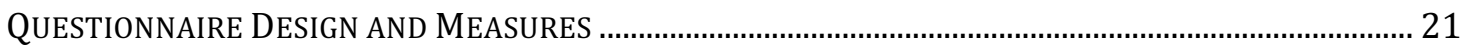

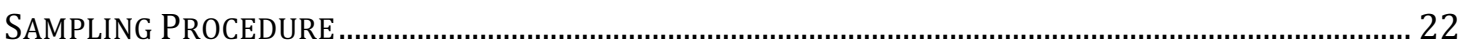

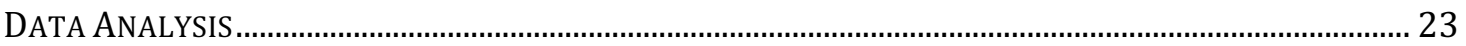

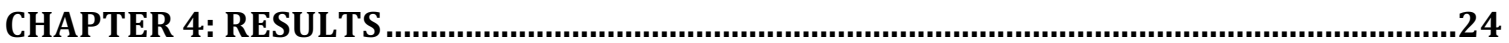

PRE-SURVEY

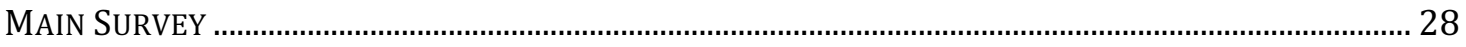




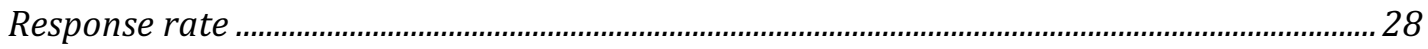

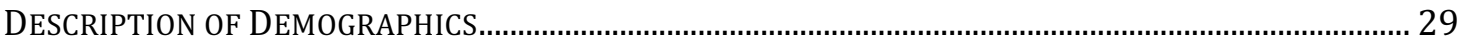

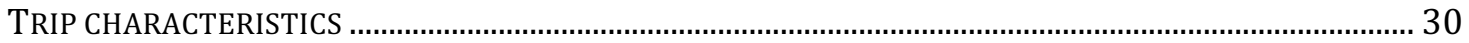

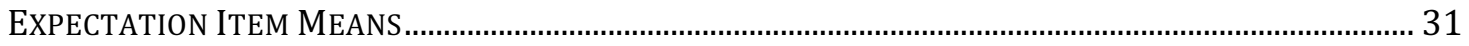

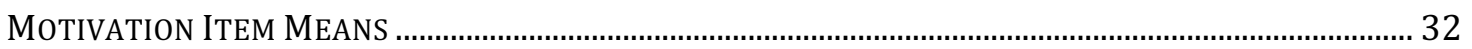

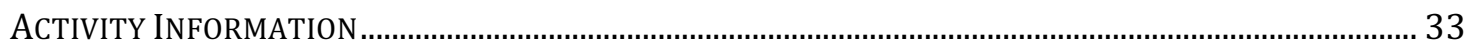

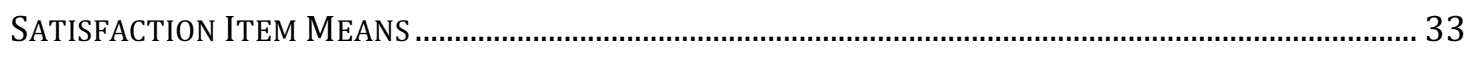

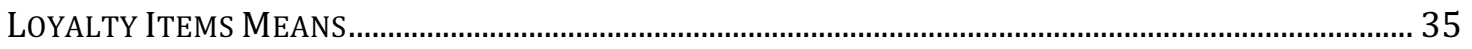

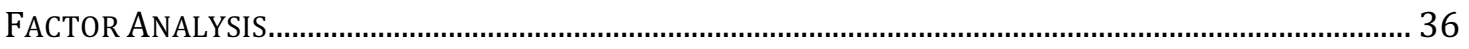

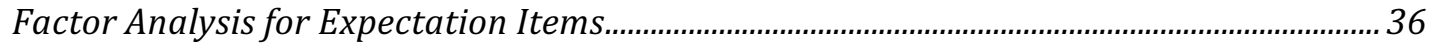

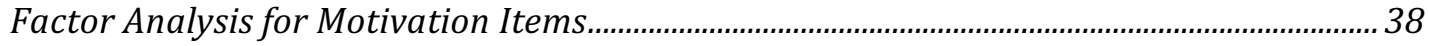

Factor Analysis for Satisfaction and Loyalty Items ............................................................... 41

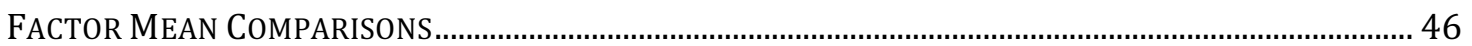

STRUCTURAL EQUATION MODEL ..................................................................................................... 52

CHAPTER 5: DISCUSSION ...................................................................................................56

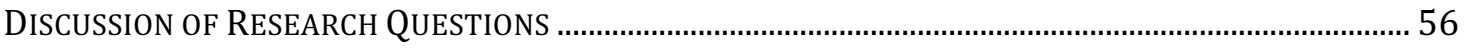

RQ1: What are the expectations of visiting the WVU OEC?....................................................56

RQ2: What are the Motivations of visiting the WVU OEC? ....................................................5

RQ3: How satisfied are the participants with their visit? .....................................................5 57

RQ4: What are the similarities and differences between the four user groups?................... 59

Discussion of SEM Findings and Hypothesis Testing ................................................................ 64

RQ5: What will bring about the highest return visitation ........................................................ 66

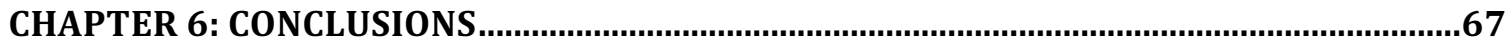

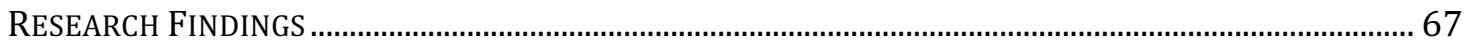

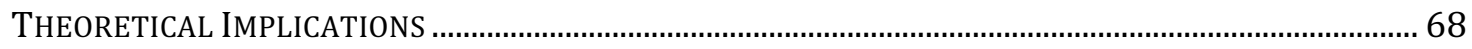




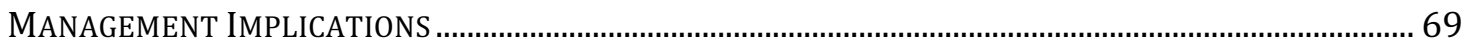

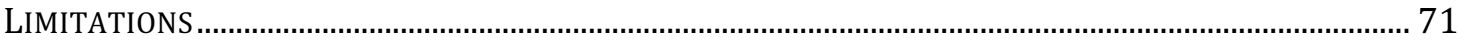

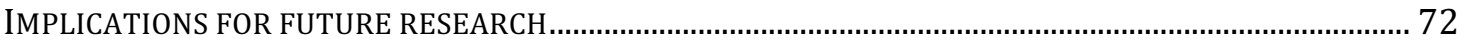

BIBLIOGRAPHY

APPENDIX

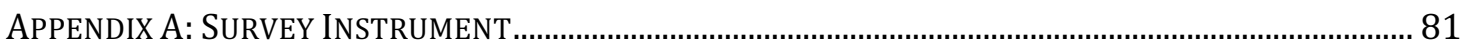




\section{LIST OF FIGURES}

Figure 1: WVU OEC Location (Courtesy of google.com/maps) .................................. 2

Figure 2: WVU OEC Boundary (Courtesy of google.com/maps) .................................. 3

Figure 3: Structural Equation Model (SEM) .............................................................. 54 


\section{LIST OF TABLES}

Table 1: Pre-Survey Activity Participation.................................................................... 24

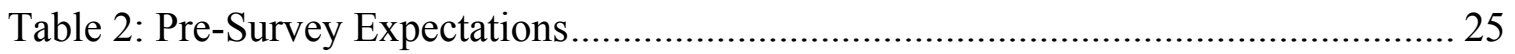

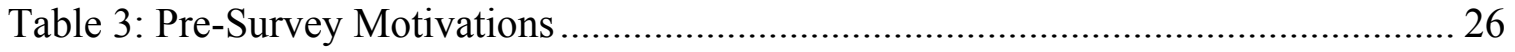

Table 4: Expectation Items Derived from Qualitative Survey..................................... 27

Table 5: Motivation Items Derived from Qualitative Survey ....................................... 28

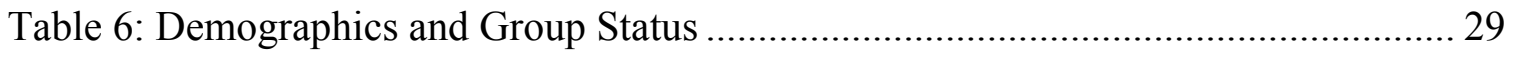

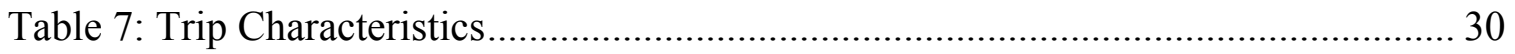

Table 8: Maximum and Minimum Expectations Organized by Mean ........................... 31

Table 9: Maximum and Minimum Motivations Organized by Mean............................. 32

Table 10: Satisfaction Organized by Section then Mean............................................ 33

Table 11: Loyalty items organized by mean.......................................................... 36

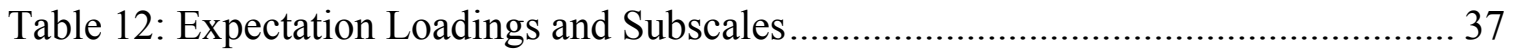

Table 13: Motivation Loadings and Subscales ........................................................ 39

Table 14: Satisfaction and Loyalty Loadings and Subscales...................................... 42

Table 15: Return Guests and First Time Guest Factor Mean Comparison...................... 46

Table 16: Male and female factor mean comparison .............................................. 47

Table 17: Program contact and non-program contacts factor mean comparison.............. 48

Table 18: Which Activity Did You Participate In? - ANOVA Post-Hoc LSD ............... 49 


\section{CHAPTER 1: INTRODUCTION}

In 2003, Adventure West Virginia began as a West Virginia University

Recreation, Parks, and Tourism Resources master's program project designed to increase freshman retention rates at West Virginia University (Hoden, 2010). By using a curriculum designed around adventure, experiential education, and university orientation Adventure WV proved to be a key resource in retaining students after their freshman year at WVU.

Through the years, Adventure WV has evolved from simply being a freshman orientation program, to being an entire department within West Virginia University Department of Student Life that embodies study abroad opportunities, sophomore reorientation, the Outdoor Recreation Center, the Recreation Center Climbing Wall, and the Outdoor Education Center (OEC). Each portion of Adventure WV is managed with the core values of adventure, integrity, student-centric, community and collaboration, quality and professionalism, and challenge.

As Adventure WV expands, so does each of its individual departments. The OEC has evolved from a single high ropes course in 2007 to now having three high rope team building elements, eight ground based team building elements, an outdoor yurt classroom, and the first university owned and operated zip line canopy tour. In addition to these elements being added, the Westvaco Natural Resources Conference Center is also managed by the OEC, which allows for groups to have access to a conference area. As the 2016 season began, the Adventure Base Camp was completed with its first phase on construction adding four new yurts and a bathroom facility. 
Not only have the facilities been updated, but general staffing needs also greatly increased, which in turn, brought on many new positions within the OEC. With the onboarding of new staff and policies, the OEC is changing at a rapid pace. As the values of Adventure WV are core to the actions taken by the staff at this facility, the team wants to insure a continued direction of success into the future.

Shown in Figure 1 below, the OEC is located about 30 minutes by car from Morgantown, WV, off the Coopers Rock exit of interstate 68, in Coopers Rock State Forest.

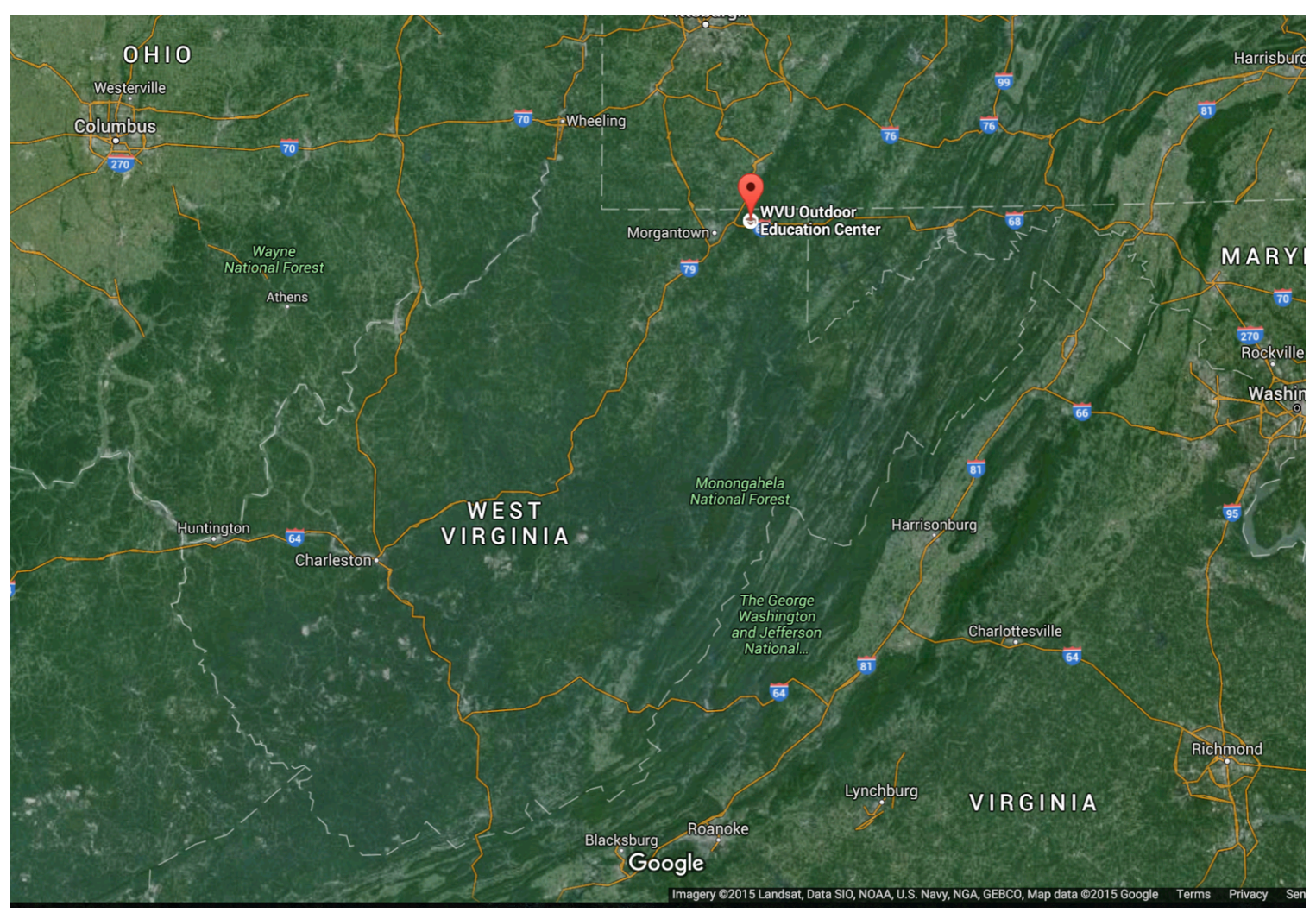

Figure 1: WVU OEC Location (Courtesy of google.com/maps)

Figure 2 below shows the boundary of the Outdoor Education Center, which is located off Chestnut Ridge Road, Bruceton Mills, WV, close to Chestnut Ridge Community Park. 


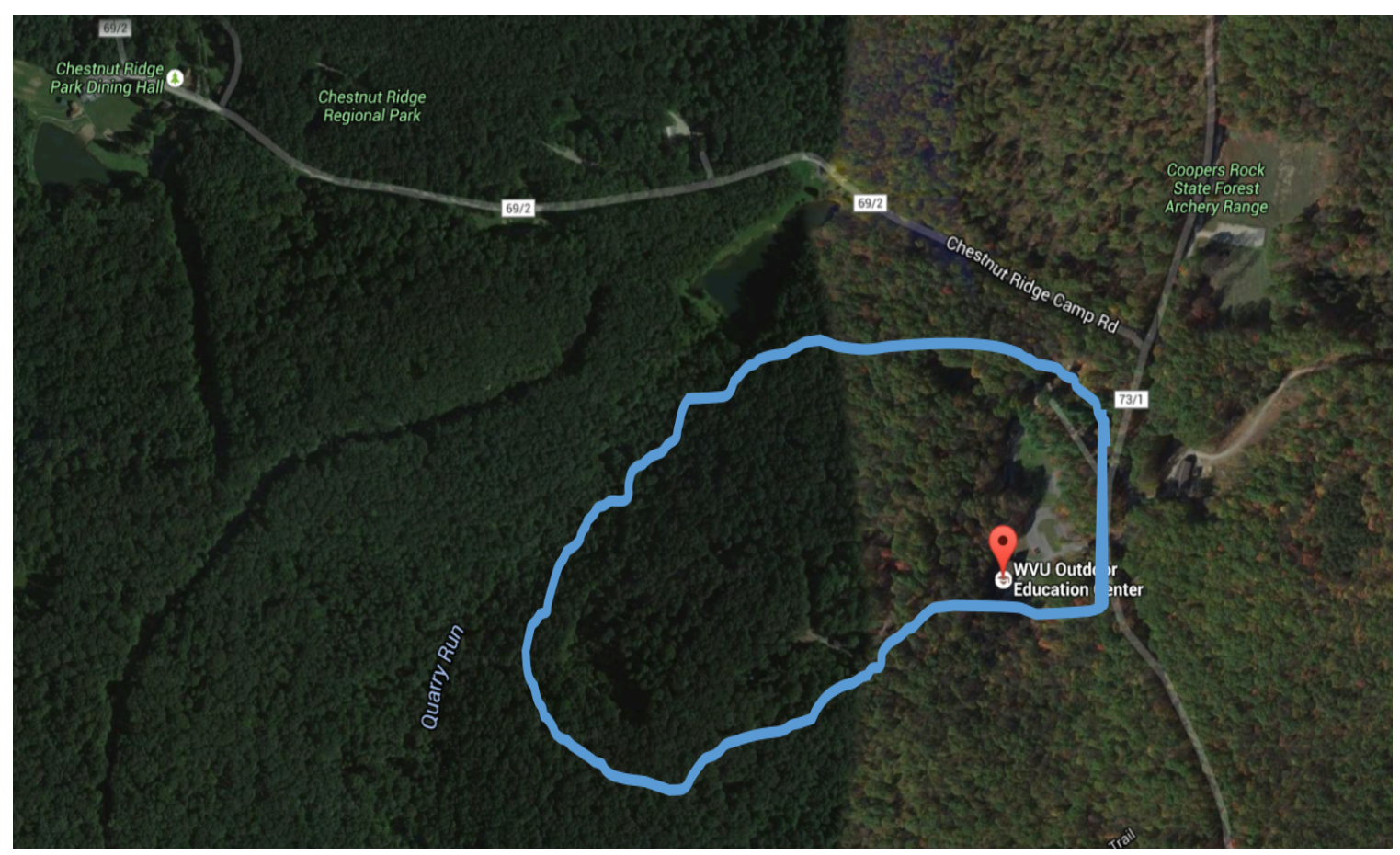

Figure 2: WVU OEC Boundary (Courtesy of google.com/maps)

With the facility being located fifteen miles outside of the Morgantown area, the OEC is a resource used by groups consisting not only of WVU students, staff, and faculty, but also nonprofit organizations, corporations, and the general public. During the time of the study, general facility construction and expansion was taking place and created a significant impact on the overall feeling of the surrounding area. With the rapid development and expansion, there comes a need to understand the clientele of the OEC. However, no studies have been conducted to understand the market in terms of what they expect at the OEC, why they are motivated to come to the OEC, how satisfied they are with the OEC, and how likely it is that they will be loyal to the OEC. Answers to these questions will help to make robust decisions on the sustainable development and management of the OEC. 


\section{Purpose of Study}

As new facilities have been added to the OEC, there has been an increase in policies and procedures that are used on the daily basis. With proper training and guidance from the management team, the facilitators at the OEC provide a valuable service to the customers. These services, like any other service are "unique in their intangibility, heterogeneity, and inseparability from production and consumption; they are each one of a kind" (Parasuraman, Zeithaml, \& Berry, 1985, p. 42).

With Adventure WV generally being accessible only to the WVU student body, the OEC has a significant role in community outreach, as it is the only portion of Adventure WV to market programming to the general public. Not only can student facilitators provide these services, but the OEC also offers trainings to community members, so they too can expand their learning, and get the chance to facilitate others.

With the upgrades to the OEC, there is a gap of information in how precisely the expectations and motivations can predict satisfaction and loyalty of the participants participating at the OEC. The scope of this study is to find who the users of the OEC are, what motivates people to be interested in programs at the OEC, and if their satisfactions correspond with their expectations. The final portion of this study will focus on the relationship between expectation, motivation, attribute satisfaction, overall satisfaction, and loyalty at the OEC.

Programs at the OEC are developed through means of a needs assessment designed by the group coordinator. This needs assessment gives the assigned facilitators an idea of what the group wants to get out of the experience at the OEC. After receipt of the needs assessment, the lead facilitator develops a program plan to meet the needs of 
the group to the best of his/her abilities. After the program has been completed, the group leaves and goes on with their day.

Looking at the feedback previously gathered from program participants, we find there is occasionally a lack of communication between group contacts and actual program participants. Many times, people will come to the OEC for a completely different reason than they expected. This study will cross-reference these market segments with the expectations and motivations to participate in programming at the $\mathrm{OEC}$ as well as their satisfaction and loyalty. The management team at the OEC will use the data found after each program for immediate staff feedback. Immediate feedback to the facilitators will bring about better satisfaction rates to the groups and helps with risk management in the long run. Over time these surveys will be used to check long-term satisfaction and loyalty of programming.

\section{Statement of Research Questions}

In moving forward with the current direction of the OEC, there are a few challenges that this research will attempt to address. Although there is not an average group of participants at the $\mathrm{OEC}$, most programming is geared toward educational groups. On both the canopy tour and challenge course, college groups are the main target. The OEC also looks at community groups such as non-profits who want to do some sort of outdoor recreational activity or team building.

The canopy tour does limit the amount of people on a four zip line, seven platform tour to eight participants and two canopy tour guides. This can usually serve twenty-four participants in a three-hour period. The challenge course on the other hand, can handle much larger groups. With both high rope elements at capacity, about fifty to 
sixty participants can be engaged at a single time. If the group does not prefer to be off the ground, they tend to do the ground based team building challenges, which facilitates over one hundred participants.

When a group organizer contacts the $\mathrm{OEC}$ with an activity plan, there is usually not a description that fits every person within the group. This makes it difficult to emphasize different aspects of the program. The group contact is relied heavily upon to relay this information to the participants to insure the best understanding of their upcoming trip to the OEC.

On the other hand, the OEC does open the canopy tours to the general public, even people who do not have large groups. A potential customer can register online for up to eight canopy tour spots. This allows for some interesting group dynamics when the group finally comes together. For instance, one canopy tour can have a full family of eight, or one canopy tour can have four couples of two. None of these tours turn out exactly the same, therefore, each guide will facilitate the tour to the best of his/her ability.

Knowing all of these possible situations can make it seem that there is an endless amount of options for someone organizing a trip to the OEC. For these reasons the OEC managers are interested in what causes participant groups to not only be satisfied with their programming, but what makes them come back for more activities. To get to this point, we will look at what they expect when they come to the OEC, and from there, what are their motivations in moving further. The final piece will consider four different types of participant groups: First-time vs. Return Visitors, Male vs. Female, Program organizer vs. normal participant, and Canopy Tour vs. Challenge Course vs. Both.

This study will focus on the following research questions: 
1. What are customer expectations of visiting the WVU OEC?

2. What are the motivations of visiting the WVU OEC?

3. How satisfied are the participants with their visit?

4. What are the similarities and differences between the four user groups?

5. What will bring about the highest return visitation?

In the following chapters, this thesis will present the review of literature, the research hypotheses, research methodology, results, and discussion of those results and the conclusions 


\section{CHAPTER 2: LITERATURE REVIEW}

The purpose of this section is to provide background information on the topics covered in this thesis. These topics include expectations and motivations as they apply to adventure recreation. The literature review will then look at the pieces of satisfaction and how they can lead loyalty.

\section{Expectations}

Many have defined adventure recreation, but for the purpose of this paper, Ewert and Hollenhorst (1997) define it as "recreational activities that contain structural components of real or perceived danger and usually involve natural environments in which the outcome is uncertain but influenced by the participant." (p. 21) Previous to this, Ewert (1989) found the growth of popularity in the outdoor adventure pursuits industry due to the acquisition and demonstration of competence and ability found by those involved in the activities. With a growing need for the industry, researchers developed various strategies in defining expectations of those activities.

Crompton, MacKay \& Fesenmaier (1991) define an expectation as “a participant's belief about the level of attributes possessed by a service" (p. 17). With this in mind, the authors went on to find desired quality is likely to be influenced by the accumulation of past experiences (Cadotte, Woodruff, \& Jenkins, 1987; Crompton, MacKay, \& Fesenmaier, 1991). Knowing West Virginia has an abundance of recreational resources, it is likely some of the visitors have been to various places around the region with challenge courses and zip lines. With Adventure WV being education based, there are, at times, some different expectations when visiting the OEC. Many of the organizations with the same type of resources are based around a pay-to-play logic. This logic allows a recreational experience to act for itself and be purely about the experience, 
this, in turn has the possibility to distort pre-exposure variables such as expectation that can predict satisfaction (Oliver, 1980).

When pre-exposure variables such as expectation are directed toward specific portions of the entire visit, it is important to differentiate between these expectations. Langgat, Marzuki, Fabeil, and Dahnil (2012) linked expectations of various aspects of an experience to its corresponding satisfactions to get a better understanding of why their survey participants are satisfied or dissatisfied with a specific portion of their event. In linking these expectations to related satisfactions, the researchers are able to show a relationship between these items.

To better fit the expectations of recreational needs, a land manager may use the Recreation Opportunity Spectrum (ROS) (Clark \& Stankey, 1979; Manning, 2011) to display these assets in specific areas of land management. The ROS is a tool that associates activities and level of management to different pieces of the land based upon three main categories-physical, social, and managerial with specific classes in each. Clark and Stankey (1979) used six different factors within these categories, including access, nonrecreational resource use, onsite management, social interactions, acceptability of visitor impacts, and acceptable regimentation of management.

In implementing these strategies, managers can give the guests to their area a better understanding of what to expect on their route. Although these are some ways to mitigate challenges involved in adventure recreation, not all trips end the same. It is up to the provider to effectively give a general understanding of what should and could happen during an experience. When the actual experience varies from what is expected, it could positively or negatively impact the overall satisfaction of the guest (Baker \& Crompton, 2000; Mackay \& Crompton, 1988). 
The expectancy theory, introduced by Victor Vroom (1964) shows people engage in specific settings to realize psychological outcomes or goals that are known, expected and valued. An expectation must have a value toward a subject for it to serve as a motive and therefore, motivations are a direct product of expectations. Moving from expectations to motivations, we will see valuable relationship between the two.

\section{Adventure Recreation Motivations}

Although expectations can initiate someone to want to do an activity, these expectations usually have some sort of underlying motivation. A motive is defined as an internal force that produces, guides and integrates behavior (Dann, 1981; Iso-Ahola, 1980). A motivation needs an expectation, or goal for it to occur(Hsu, Cai, \& Li, 2010). Looking back at the Expectancy Theory (Vroom, 1964), motivations are the need to pursue the aforementioned goals, and are a product of valence and expectation (Hsu et al., 2010; Wong, Cheung, \& Wan, 2013).

As the recreation industry builds, so does the knowledge around why people recreate. "Motivations contain results of situation-person interactions. They are a collective term for processes and effects with common parameters: in a particular situation, a person chooses a certain behavior for its expected results" (Gnoth, 1997, p. 288). While there are many ways to intrigue someone's expectations, motivations are the reason that an individual actively picks one activity over another. Adventure recreation is a concept that embodies activities that some may call a death sentence like skydiving or zip lining for example. Adventure recreation can also be something that you do on a Sunday afternoon, such as skiing or hiking. No matter why someone recreates, people participate in outdoor recreation because it provides social, physiological, and psychological benefits (Manfredo, Driver, \& Tarrant, 1996; Manning, 1999). These three pieces 
are components of motivations and when combined, can determine why someone will choose to go skydiving over skiing.

Although there are quite a few major reasons to study these motivations, Dann (1977) describes two different categories or factors of motivation. The first factor that he describes is the push factor, which includes personal internal reasons such as escape or nostalgia. Klenosky (2002) describes these push factors as "wants and needs of the traveler" (p. 385). Conversely, the other factor of motivations is the pull factor, which includes the outer influences that attract the visitor such as sunshine, the sea, or marketing (Yoon \& Uysal, 2005). The knowledge of the separation of these two factors is important to note, as it exemplifies how to reach consumers in various ways (Kim, Oh, \& Jogaratnam, 2007).

At the OEC, a number of push and pull factors have been examined to market different programs. Being that the OEC is in the WVU Research Forest, it is surrounded by nature and is rather quiet due to the location being about thirty minutes from downtown Morgantown and twenty minutes from the nearest town of Bruceton Mills, WV. There has also been a large pull from the Adventure WV community to get "miles away from every day" (Adventure West Virginia, 2016).

Push factors of the OEC have not been explored as much due to the lack of previous survey information pertaining to the topic. Research previously gathered from undergraduate recreation majors from a different university has given insights into what can push people into recreational experiences at a university as noted by Todd, Anderson, Young, and Anderson (2002):

First, fun is the number one motive and needs to be heavily emphasized when planning and implementing programs. Second, these results reveal that there are more ingredients 
to challenge than simply risk-taking. Feelings of achievement, novelty, fitness, excitement and stimulation, and skill development are also highly related to the theme of personal challenge. Structuring and facilitating adventure activities that produce these outcomes would tend to satisfy participants to the greatest degree. Third, comparisons with others should be avoided when conducting such programs, but emphasis on personal growth and development would be appropriate based on this ranking of motives (2002, p.

While there are plenty of motivations that push and pull a participant into adventure recreation activities, some motivations change according to specific demographics. Studies like Sugarman (2001) used the Recreation Experience Preference (REP) Inventory developed by Driver (Driver, 1977; 1983) to measure these motivations in groups like retirees. Driver's REP inventory identifies several motivations toward recreating. A survey using the REP can classify participants by asking queries according to anticipated results of recreational experiences. For example, Sugarman (2001) used the REP Inventory to examine motivations across retirement status, level of skill development, age and gender, finding that gender is an indicator for the categories of nature, physical fitness, learning and social security. The categories of taking risk, nature, learning, and physical escape are also found to be significantly different between levels of experience.

Within the REP inventory there are 21 overarching categories such as nostalgia, physical fitness and enjoy nature. These categories are then divided into subcategories like exercisephysical fitness which then consists of a multitude of statements like "to get exercise" and "to tone up my muscles" (Driver, 1983, p. 6). 
According to Dann (1977), a key motivation for travel is the push to get away from anomie. Rose (1966) defines anomie as a society in dystopia. A society with anomie present has “a breakdown of social standards governing behavior and signifies little social cohesion” (p. 30). This concept of anomie is considered a push factor; although reasons for anomie are coming from outside sources, anomie itself, is what is causing the subject to travel. In previous literature, anomie has only been used to describe society, but as the article states, it can also be used to describe a displeasing lifestyle. It is also important to note that Dann (1977)found anomie in subjects with various lifestyles, including people residing in cities or in rural settings.

Combining literature from this section, tourists rarely travel for simple reasons (Hvengard, 2002; Luo \& Deng, 2007). While most studies have developed measurement scales by drawing upon findings from the literature, some (Holden \& Sparrowhawk, 2002; Hvengard, 2002; Luo \& Deng, 2007) recommended statements measuring motivations be better derived directly from participants via. a qualitative study. Manfredo, Driver, and Tarrant (1996) then suggest including items of high importance and variability in the final instrument.

With this in mind, motivation is of high importance when deciding how to manage a recreational resource. Yoon and Uysal state that marketing destinations needs to be driven by previous research on a tourist motivation analysis and how this relates to satisfaction and loyalty (2005). Crompton and Mckay (1997) exemplify the need to understand motivations because customers are investing in their expectations to benefit in satisfying a need. While motivations toward an activity can direct interest toward a behavior, it is also important to understand the adventure tourists' satisfaction, because it is central concept of understanding tourism behavior (Ross \& Iso-Ahola, 1991). 


\section{Satisfaction}

Satisfaction is defined by Tse and Wilton (1988) as "an evaluation of the perceived discrepancy between prior expectations and the actual performance of the product" (p. 204). As previously stated, Oliver (1980) argues satisfaction will be positively affected when expectations are met. Crandall (1980) also states that most of human behavior is directed by goals, needs or satisfaction.

Lewis and Booms (1983) indicate service quality is a measure of how well the service level delivered matches the customer expectations. In the adventure recreation field, service quality was measured by the satisfaction with the recreational activity (Manning, 1986). Previous studies (Crompton, MacKay, \& Fesenmaier, 1991; Mackay \& Crompton, 1988) have shown if the experience meets the expectations, the experience will be satisfactory. If an experience exceeds those expectations, the participant will be highly satisfied. Conversely, if the experience is inferior to those expectations, the guest will be highly unsatisfied. Higher quality of performance and levels of satisfaction are perceived to result in increased loyalty and future visitation, greater tolerance of price increases, and an enhanced reputation (Baker \& Crompton, 2000).

Working on the front lines in the adventure tourism industry gives an employee a direct influence into the guest's overall satisfaction. The satisfaction profit chain (Frennea, Mittal, and Westbrook, 2014) shows organizational inputs such as investments in front-line employees, have a direct positive correlation to overall satisfaction, and subsequently the decision variables that are made by the customer. Although service quality is seen directly through the front-line employees, this customer service trickles down from the top managers (Ellis \& Rossman, 2008). Ellis and Rossman (2008) noted that it is difficult to gauge the understanding and skills of 
seasonal employees and evaluate their need for training due to their minimal employment periods. A direct effect of this is sometimes lack of proper training.

In a study conducted by Tsuar, Lin, and Cheng (2015), perception of challenge along with flow experience in an adventure recreation activity were directly correlated to the overall satisfaction. Ellis and Rossman (2008) exemplify how important the first impression and satisfaction of a destination can be. According to Williams and Soutar (2009), another factor that can greatly effect experience satisfaction is value.

Lee, Grafe, and Burns (2007) show an abundance of studies (Boulding, Lakra, Staelin, \& Zeithaml, 1993; Oliver R. L., 1997; Ostrowski, O'Brien, \& Gordon, 1993; Ziethaml, Berry, \& Parasuraman, 1996) that link satisfaction, service quality, and loyalty with a significantly positive relationship. Findings of Williams and Soutar (2009) show satisfied visitors can have a large impact on future business by creating word-of-mouth and repeated visitation. It determines if the customer will come back and/or tell people about the destination or if they will go somewhere else and tell people not to go there.

As a site with a diverse selection of activities, the OEC can facilitate many different types of programs and groups. With the growing site, more visitors will be able to participate than ever before. In attempting to sustain high customer satisfaction, the OEC staff wants to ensure that every part of the experience is valuable to the customer. In matching these various perceptions to their expected experience, we hope to create a loyal customer that creates word-of-mouth and return visitation. A more detailed description of loyalty follows. 


\section{Loyalty}

Andreassen and Lindestad (1998) define loyalty as "an intended behavior related to the service or the provider" (p. 84). Gronholdt, Martensen, and Kristensen (2000) conducted surveys across several industries based on variables leading to customer satisfaction, finding a positive correlation between overall satisfaction and loyalty to the respective business. This positive link between satisfaction and loyalty was also supported by De Ruyter, Wetzels, Lemmink, and Mattson (1997) who found that a good customer satisfaction can lead into a long-term relationship with the customer.

Loyalty, described by Oliver (1999), envelops three distinct variations that include Attitude, Intention, and Actual loyalty. These can be looked at further as affective, cognitive and behavioral stages, respectively. These stages show that loyalty is a multifaceted system (Lee et al., 2007). In conjunction with these findings, Frennea et al. (2014) indicate that portions of the satisfaction profit chain such as a wholistic understanding of satisfaction, inputs from the company and employees, and meaningful value help to formulate the loyalty component as well as other decisions made by the customer.

Hallowell's (1996) findings revealed a strong relationship for satisfactions, leading to loyalty, which in turn, leads to profitability. Findings of Olivia et al. (1992) show even a small increase of customer satisfaction can significantly increase profitability. Coyne (1989) revealed the "twin threshold framework" which shows, once the satisfaction reaches these threshold points on the high/low scale, the rate of loyalty is exponential in the corresponding direction. Hallowell's (1996) study found skipping loyalty leads to lower overall profitability than including it in a profitability equation. 
Loyalty to a specific product is like shopping through the grocery store, always buying the same items. Bowen and Chen (2001) state "loyal customers indeed provide more repeat business and were less likely to shop around for the best deals than non-loyal customers" (p. 215). Being loyal to a destination, visiting a place repeatedly and telling others about it, is not quite as simple. Lee et al. (2007) support this argument by stating "unlike brand loyalty, destination loyalty displays more complexity and variability" (p. 477).

In terms of the OEC, many group organizers do decide to return year after year. Whether they bring the same participants more than once is usually not recorded internally, however, some groups do choose to have on-going teambuilding throughout a semester, year, or major program completion. Some university programs participate in the challenge course elements year after year for orientation and group development. Group organizers who frequent the canopy tour appear to be interested in enjoying the outdoors or trying new things. With a continued relationship between these groups and the OEC, we would like to determine the largest contributions to the continued programming.

\section{Previous Study findings}

From the literature reviewed above, there are some significant findings. Expectations significantly predict motivations when visiting a tourist destination (Hsu et al., 2010; Lee, Jeon, \& Kim, 2011). Pre-exposure variables such as expectations and motivations can signify levels of satisfaction (Langgat, Marzuki, Fabeil, \& Dahnil, 2012; Oliver, 1980; Wong et al., 2013). There is a significant positive correlation from motivation to satisfaction (Crompton \& Mckay, 1997;

Dann, 1981; Ross \& Iso-Ahola, 1991; Wong et al., 2013). Itemized expectations and motivations can significantly indicate their corresponding satisfactions respectively (Langgat, Marzuki, 
Fabeil, \& Dahnil, 2012). Satisfaction significantly indicates loyalty (Andreassen \& Lindestead, 1998; Gronholdt et al., 2000; Lee et al., 2011; Oliver, 1999; Yoon \& Uysal, 2005).

Based on the literature review and its findings above, the following 10 hypotheses were proposed:

Hypothesis 1: The higher expectations participants have, the more motivated they will be. Hypothesis 2: Participants with a higher level of expectation will be more satisfied with their activities at the OEC.

Hypothesis 3: Participants with a higher level of expectation will be more satisfied with OEC staff/facilitators.

Hypothesis 4: Participants with a higher level of motivation will be more satisfied with their activities at the OEC.

Hypothesis 5: Participants with a higher level of motivation will be more satisfied with OEC staff/facilitators.

Hypothesis 6: A higher level of expectation will lead to a higher level of overall satisfaction. Hypothesis 7: A higher level of motivation will lead to a higher level of overall satisfaction. Hypothesis 8: Satisfaction with activities will significantly contribute to overall satisfaction. Hypothesis 9: Satisfaction with staff/facilitators will significantly contribute to overall satisfaction.

Hypothesis 10: Participants who are more satisfied overall will be more loyal to the OEC. 


\section{CHAPTER 3: METHODS}

This chapter consists of four subsections. The fist subsection presents methods and procedures for data collection, followed by the second subsection dealing with questionnaire design and measures on expectation, motivation, satisfaction, and loyalty. The third and fourth subsections focuses on sampling procedures and data analysis respectively.

\section{Data Collection}

\section{Pre-survey}

In late April of 2016, a four-question online pre-survey was distributed to spring season participants of both the challenge course and the zip line canopy tour through the online survey platform - Qualtrics provided by WVU. The main purpose of the pre-survey was to qualitatively derive items to measure expectations and motivations to be used for actual survey of participants at the OEC. This qualitative approach of obtaining measure items from pre-survey of participants, instead of directly drawing upon findings from the literature follows suggestions by Holden and Sparrowhawk (2002) and Luo and Deng (2007) (for advantages of using this approach, please refer to their papers).

Questions from this survey include activities previously participated in at the OEC; "what are the top five motives for your participation at the WVU Outdoor Education Center?"; and "what were your top five expectations when coming to the WVU Outdoor Education Center?" Participants were also asked to provide their contact information so that their names could be entered into a drawing of two free canopy tour spots on the updated canopy tour experience.

\section{Survey}

Once the data was compiled from the pre-survey, the information obtained on expectation and motivation was then inserted in the actual survey questionnaire which was approved by the 
WVU IRB (Institutional Review Board). This five-part survey consisted of previous knowledge of the OEC, expectations of participation, motivations of participation, attribute-level satisfaction, satisfaction of the overall experience and return visitation, along with general demographics and trip information.

Upon finishing an OEC program, email addresses were gathered from participants 18 and older by managers and facilitators of programs at the OEC. A blanket statement which involved the theme "helping graduate student surveys and helping data collection to better suit the needs of future participants" was used by either the lead program facilitator or the manager on duty for the day. These specific individuals were utilized because they are the leaders of their respective activities.

A survey invite from Qualtrics was also automatically sent to the group contact through the email provided for logistical contact. Qualtrics was used for this survey, as it is supported by WVU and transfers into SPSS. This allowed for at least one person from each group to have a chance to respond to the survey. All groups opted for at least one additional person to receive an email invite. An email with the online survey link was sent to those participants with email addresses one week after. An incentive of winning two canopy tour spots or a $\$ 25$ gift card was mentioned in the email.

Following Dillman's Total Design Methods (2000) for mailed-questionnaire survey, a follow-up reminder email was sent to those who did not complete the survey. Another follow-up email was sent to who have not completed the survey within three weeks. Finally, a thank-you email was sent to all participants that completed the survey within four weeks. 


\section{Questionnaire Design and Measures}

A questionnaire consisting of five sections including Previous Knowledge, Expectations, Motivations, Satisfactions and Loyalty, and Demographics was designed based on the literature, inputs from this thesis research committee members, and results on motivation and expectation from the pre-survey.

Section 1 - Previous Knowledge looked at how familiar the participant is with the OEC. Questions asked include "Before scheduling your program, have you heard of the WVU OEC?" and how?" There were also true and false statements which asked how much participants agree on a 5-point Likert Scale.

Section 2 of the survey consists of 30 items measuring participants' expectations obtained from the pre-survey. Example items include Making memories, Having fun, Having a nice event and Having an Adventure. Participants were asked to indicate the extent to which they agree or disagree with each statement on a 5-point Likert scale ranging from $1=$ Strongly Disagree to $5=$ Strongly Agree. Some of the keywords from the pre-survey include: zip lining, fun, safe, learn, activity, experience, people and bucket list.

Section 3 of the questionnaire has 38 statements measuring participants' motivations. As with measures on expectations, these items were obtained from the pre-survey. Example items include To have Fun, To enjoy the company of people who came with me, To Build Relationships and To be Challenged. Participants were asked "Listed below are motivations of adventure recreation programming. Please indicate how much these categories motivated you to participate today by choosing your response." This was done on a 5-point scale ranging from $1=$ Not at all to $5=$ A Great Deal. Some of the keywords from the pre-survey include: fun, family, activity, nature, outdoors, adventure and WVU. 
The first portion of Section 4 involved one item of overall satisfaction and 30 items that measure participants' attribute-level satisfaction with every aspect of their participation, including setting, signage, activities, staff/facilitators, programming, etc. Participants were asked to indicate how much you agree or disagree with each statement by responding to a 5-point Likert scale $(1=$ Strongly Disagree, 5 = Strongly Agree $)$ on phrases about satisfactions with various parts of their experience. These phrases were derived from general questionnaires and interests of the research committee.

The latter portion of Section 4 measures participants' loyalty to the OEC. Specifically, participants were asked to indicate their intentions to revisit and recommend to others. To keep consistency in the survey, a 5-point Likert scale ranging from $1=$ Strongly Disagree to $5=$ Strongly Agree was used. The phrases in this section were based upon questions from Lee et al.'s (2007) research on destination loyalty.

Finally, Section 5 gathered information on participants' socio-demographics and trip information, including gender, age, education, group organizer status, group status, group affiliation, group size, and residency. An open comment section for the OEC and this study was also included. In addition, participants were asked to provide their contact information for the aforementioned incentive purpose.

\section{Sampling Procedure}

The sampling was done by convenience by asking all willing participants to complete the study. A survey invite was automatically sent to the group contact through the email provided for billing. This allowed for at least one person from each group to have a chance to respond to the survey. All groups opted for at least one additional non group contact person to receive an email invite. 


\section{Data Analysis}

The data was then analyzed in five steps. First, pre-survey and main survey data were compiled using Qualtrics provided by WVU. The data from Qualtrics was then transferred to SPSS for further analysis of descriptive statistics. Second, factor analysis with varimax rotation was conducted on the expectation, motivation, satisfaction and loyalty measures. Third, t-tests and ANOVA tests were conducted to compare the similarities and differences between the four groups. The groups being tested were return and first time visitors, male and female, program contact and participant, and activity choice between canopy tour, challenge course, or both in the same day. Finally, Structural equation modelling (SEM) using AMOS 24.0 was conducted to test the interrelationship between expectation, motivation, satisfaction, and loyalty. 


\section{CHAPTER 4: RESULTS}

The first portion of this chapter includes the results of the qualitative pre-survey. The rest of this section concerns the main survey resulting from that. First comes the frequency of demographic data found in the main survey. Following the demographics, descriptive statistics of individual expectation, motivation, satisfaction, and loyalty are shown. After this we performed a factor analysis on expectations, motivations, satisfactions and loyalty along with their KMO and Bartlett's Test of Sphericity and Initial Eigenvalues. The next steps of this analysis were to find the differences between user groups using independent sample t-tests, and later activities participated in by use of ANOVA and LSD Post Hoc Analysis. After the mean comparison testing, a structural equation model (SEM) was developed to show the relationship between the important constructs within the study.

\section{Pre-Survey}

Out of 17 respondents in table 1 below, $14(82.4 \%)$ went on the canopy tour, two $(11.8 \%)$ went on the challenge course, and one (5.9\%) did both activities.

Table 1: Pre-Survey Activity Participation

\begin{tabular}{|c|c|c|}
\hline Activity & Frequency & Valid Percent* \\
\hline Zip Line Canopy Tour & 14 & $82.4 \%$ \\
\hline Challenge Course Programming & 2 & $11.8 \%$ \\
\hline Both & 1 & $5.9 \%$ \\
\hline Total & 17 & $100.0 \%$ \\
\hline
\end{tabular}

* The valid percent values were used to exclude cases with missing data.

From the responses in these two questions, sections $2 \& 3$ of the primary survey were developed by comparing general responses to Driver's $(1977 ; 1983)$ study. In table 2 below, each expectation response was separated and the exact responses have been shown verbatim. 
Table 2: Pre-Survey Expectations

\begin{tabular}{|c|c|}
\hline Response & $\begin{array}{l}\text { What were your top five expectations when coming to the WVU Outdoor } \\
\text { Education Center? }\end{array}$ \\
\hline 1 & $\begin{array}{l}\text { Education, recreation, sport, field trip, first time zipper for many of our } \\
\text { students }\end{array}$ \\
\hline 2 & Learning, adventure, new experience, fun, memories \\
\hline 3 & $\begin{array}{l}\text { Team building, self-esteem building, pushing limits, thinking skills, } \\
\text { getting to know each other }\end{array}$ \\
\hline 4 & $\begin{array}{l}\text { Have fun; try something new; deepen my relationships with participants; } \\
\text { participate in meaningful reflections; see the young participants change } \\
\text { and grow }\end{array}$ \\
\hline 5 & To have fun, go fast, hang out, live life, come out alive \\
\hline 6 & Fun, checkoff bucket list, good learning opportunity, fun... And more fun \\
\hline 7 & Fun zip lining, feeling the wind in my hair \\
\hline 8 & $\begin{array}{l}\text { Have fun, be exciting and an adventure, meet cool people, learn about zip } \\
\text { lining, have a good birthday }\end{array}$ \\
\hline 9 & $\begin{array}{l}\text { Learn how zip lining works. Nice views. Professionalism. Friendly } \\
\text { service. Punctuality. }\end{array}$ \\
\hline 10 & $\begin{array}{l}\text { Safe, a good experience, something different, a small group, to learn } \\
\text { something }\end{array}$ \\
\hline 11 & Fun activity, safe activity, enjoyable outdoor activity \\
\hline 12 & $\begin{array}{l}\text { Fun, to be outside, learn safety, learn how to stop, learn to trust tour } \\
\text { leaders }\end{array}$ \\
\hline 13 & Fun, excitement, adrenaline, scenic beauty \\
\hline 14 & $\begin{array}{l}\text { Learn about trees \& stuff, vertigo, screaming, get some zip lining } \\
\text { experience, a fifth thing }\end{array}$ \\
\hline 15 & $\begin{array}{l}\text { Enjoying the outdoors, adventure, something new, learning a bit about } \\
\text { what WVU outdoor ed. has, fun!!!! }\end{array}$ \\
\hline 16 & Safe, controlled environment, no pressure \\
\hline 17 & $\begin{array}{l}\text { Will I make it through the course, not falling, having fun, meeting new } \\
\text { people, learning about the WVU outdoors }\end{array}$ \\
\hline
\end{tabular}


In table 3 below, again, each motivation response was separated and the exact responses are shown verbatim.

Table 3: Pre-Survey Motivations

\begin{tabular}{|c|c|}
\hline Response & $\begin{array}{l}\text { What are the top five motives for your participation at the WVU Outdoor } \\
\text { Education Center }\end{array}$ \\
\hline 1 & Physics behind the zip line, recreational, educational, cost, safety \\
\hline 2 & Activities, proximity to home, staff, kid friendly \\
\hline 3 & $\begin{array}{l}\text { Team building, self-esteem building, pushing limits, thinking skills, getting } \\
\text { to know each other }\end{array}$ \\
\hline 4 & $\begin{array}{l}\text { Help a group of young people build relationships, strengthen teamwork, } \\
\text { promote self-discovery and push their boundaries }\end{array}$ \\
\hline 5 & Fun, outdoor, entertainment, cool air, enjoy nature \\
\hline 6 & $\begin{array}{l}\text { Adventure, birthday surprise, love outdoors, fun close to Morgantown, } \\
\text { good company }\end{array}$ \\
\hline 7 & Enjoy fun, like trees, like the wind in my hair, corny jokes \\
\hline 8 & Fun, close to home, price, local business \\
\hline 9 & Adventure, nature, nice weather, sight-seeing, outdoor activity. \\
\hline 10 & $\begin{array}{l}\text { Fun, adventure, being outdoors, seeing nature, location (near where we } \\
\text { were staying) }\end{array}$ \\
\hline 11 & $\begin{array}{l}\text { Fun activity, new activity for us, fit in with our vacation schedule, } \\
\text { something we always wanted to do }\end{array}$ \\
\hline 12 & As a social for the food science club \\
\hline 13 & Fun, learning, supporting university activity, being outdoors \\
\hline 14 & $\begin{array}{l}\text { Fun date with husband, see if I'm still afraid of heights, feel wind in my } \\
\text { face, life is depressing and we needed adventure, better than sitting on the } \\
\text { couch }\end{array}$ \\
\hline 15 & $\begin{array}{l}\text { Good family activity during family weekend. Now that we have } \\
\text { experienced it we would do it again. }\end{array}$ \\
\hline 16 & $\begin{array}{l}\text { Beautiful day, fun family outing, something we've not done before, close to } \\
\text { WVU and outside }\end{array}$ \\
\hline 17 & Challenge, WVU family weekend, thrill, education, facing fear \\
\hline
\end{tabular}


From these responses, 30 expectation items were derived as well as 38 motivation items.

Expectation and motivation items are shown in Tables 4 and 5 below, respectively.

Table 4: Expectation Items Derived from Qualitative Survey

\begin{tabular}{ll}
\hline Making memories & Gaining knowledge \\
Having fun & Experiencing mental growth \\
Having a nice event & Experiencing an adrenaline rush \\
Having an adventure & Experiencing change \\
Enjoying new activities & Having a controlled environment \\
Exciting experience & Experiencing physical growth \\
Gaining a new experience & Having small groups \\
Experiencing friendly service & To create meaning \\
Enjoying the outdoors & Meeting new people \\
Experiencing exciting activities & Experiencing punctuality \\
Participating in safe activities & Learning about WVU \\
Recreation & Learning about the forest \\
Seeing scenic beauty & Learning about the zip line \\
Deepening relationship & Having large groups \\
Experiencing professionalism & Feeling pressure \\
\hline
\end{tabular}


Table 5: Motivation Items Derived from Qualitative Survey

To have fun

To enjoy the company of people who came with me

To build relationships

To be challenged

To be outdoors

To be adventurous

To experience something new

To develop teamwork

To be social

To push yourself

To explore

To learn

To be thrilled

To enjoy scenic view

To be entertained

To be out of my comfort zone

To experience self-discovery

To be close to nature

To support WVU activity
To enjoy the smells and sounds of nature

To be educated

To recreate

To enjoy nice weather

To lead team development

To enhance self-esteem

To be safe

To do an affordable activity

To face fear

To go sightseeing

To do something in my free time

To support local business

To be with family

Close to home

To check it off my bucket list

To recall past satisfactions

To avoid everyday life

Something to do on vacation

To go somewhere kid friendly

\section{Main Survey}

\section{Response rate}

With a total population of 2976 participants, a convenience sample of 465 participants received emails regarding the survey. Out of this sample, a total of $189(40.6 \%)$ completed the survey to its entirety. 


\section{Description of Demographics}

Table 6 presents the summary of participants' socio-demographic characteristics. As shown, out of 189 survey participants $114(61.3 \%)$ were female, whereas the remaining 72 (38.7\%) were male. Most responded as being between the ages of 18-24 (41.2\%), however, the 25-34, 35-44, and 45-54, collectively had more response (49.7\%). Forty-three participants (23.0\%) had some college education, while 79 (42.2\%) had a four-year college degree.

Table 6: Demographics and Group Status

\begin{tabular}{|c|c|c|}
\hline & Frequency & Valid Percent* \\
\hline \multicolumn{3}{|l|}{ Gender } \\
\hline Male & 72 & 38.7 \\
\hline Female & 114 & 61.3 \\
\hline \multicolumn{3}{|l|}{ Age } \\
\hline $18-24$ & 77 & 41.2 \\
\hline $25-34$ & 33 & 17.6 \\
\hline $35-44$ & 31 & 16.6 \\
\hline $45-54$ & 29 & 15.5 \\
\hline $55-64$ & 14 & 7.5 \\
\hline $65-74$ & 3 & 1.6 \\
\hline $75-84$ & 0 & 0 \\
\hline$>85$ & 0 & 0 \\
\hline \multicolumn{3}{|l|}{ Education } \\
\hline Less than High school & 2 & 1.1 \\
\hline High school graduate & 12 & 6.4 \\
\hline Some college & 43 & 23.0 \\
\hline 2-year degree & 5 & 2.7 \\
\hline 4-year degree & 79 & 42.2 \\
\hline Professional degree & 30 & 16.0 \\
\hline Doctorate & 16 & 8.6 \\
\hline
\end{tabular}

* The valid percent values were used to exclude cases where there is missing data. 


\section{Trip characteristics}

Table 7 presents the summary of participants' trip characteristics. School groups made up $62.7 \%$ of all responses and friend groups made up $22.6 \%$. On the other end of the spectrum, only one respondent indicated that he/she came as an individual. Out of all responses, $120(65.9 \%)$ were WVU students and 29 (15.9\%) were from the general public. Out of these groups, $41.2 \%$ indicated that their group consisted of 10 or less people and $35.8 \%$ said they came with $11-30$ people. From the 189 survey participants, 61 (32.8\%) indicated they were the group organizer and $100(52.9 \%)$ indicated they were return visitors.

Table 7: Trip Characteristics

\begin{tabular}{|c|c|c|}
\hline & Frequency & Valid Percent* \\
\hline \multicolumn{3}{|l|}{ Group Information } \\
\hline Individual & 1 & 0.6 \\
\hline Couple & 16 & 9.0 \\
\hline Friend group & 40 & 22.6 \\
\hline School group & 111 & 62.7 \\
\hline Club & 9 & 5.1 \\
\hline \multicolumn{3}{|l|}{ Group Affiliation } \\
\hline WVU student & 120 & 65.9 \\
\hline WVU staff & 14 & 7.7 \\
\hline WVU faculty & 9 & 4.9 \\
\hline Non-profit & 10 & 5.5 \\
\hline General public & 29 & 15.9 \\
\hline \multicolumn{3}{|l|}{ Group Number } \\
\hline Less than 10 & 77 & 41.2 \\
\hline $11-30$ & 67 & 35.8 \\
\hline $31-50$ & 19 & 10.2 \\
\hline More than 50 & 24 & 12.8 \\
\hline \multicolumn{3}{|l|}{ Group Organizer } \\
\hline Yes & 61 & 32.8 \\
\hline No & 125 & 67.2 \\
\hline
\end{tabular}


Table 7: Trip Characteristics (continued)

\begin{tabular}{ccc}
\hline & Frequency & Valid Percent* \\
\hline Return Visitor & & \\
Yes & 100 & 52.9 \\
No & 89 & 47.1 \\
\hline
\end{tabular}

* The valid percent values were used to exclude cases where there are missing data.

\section{Expectation Item Means}

From the original 189 survey participants, all were included for the remaining analyses.

Looking back to the 30 expectations that were identified in the pre-survey, the top and bottom

five responses are shown in Table 8 below. The top expectations were "Making memories" $(M=$ 4.69) and "Having fun" $(M=4.68)$. The lowest expectations described in this study were

"Feeling Pressure" $(M=3.02)$ and "Having large groups" $(M=3.19)$.

Table 8: Maximum and Minimum Expectations Organized by Mean

\begin{tabular}{|c|c|c|c|c|c|c|c|}
\hline & \multicolumn{5}{|c|}{ Percent of respondents } & \multirow[b]{2}{*}{ Mean } & \multirow[b]{2}{*}{$S D$} \\
\hline & SD & MD & $\mathrm{N}$ & MA & SA & & \\
\hline Making memories & 0.0 & 0.5 & 2.2 & 25.3 & 72.0 & 4.69 & 0.54 \\
\hline Having fun & 0.0 & 0.0 & 1.6 & 29.2 & 69.2 & 4.68 & 0.50 \\
\hline Having a nice event & 0.5 & 0.0 & 1.6 & 33.9 & 64.0 & 4.61 & 0.58 \\
\hline Having an adventure & 1.1 & 1.1 & 3.2 & 28.5 & 66.1 & 4.58 & 0.71 \\
\hline Enjoying new activities & 1.1 & 0.5 & 5.4 & 28.5 & 64.5 & 4.55 & 0.72 \\
\hline Learning about WVU & 7.0 & 10.2 & 23.7 & 35.5 & 23.7 & 3.59 & 1.16 \\
\hline $\begin{array}{l}\text { Learning about the } \\
\text { forest }\end{array}$ & 8.1 & 10.3 & 25.4 & 29.7 & 26.5 & 3.56 & 1.22 \\
\hline $\begin{array}{l}\text { Learning about the zip } \\
\text { line }\end{array}$ & 14.1 & 6.0 & 21.7 & 26.1 & 32.1 & 3.56 & 1.37 \\
\hline Having large groups & 11.8 & 15.1 & 32.8 & 22.6 & 17.7 & 3.19 & 1.24 \\
\hline Feeling pressure & 16.7 & 17.7 & 29.0 & 20.4 & 16.1 & 3.02 & 1.31 \\
\hline
\end{tabular}

Note: Items are measured using a 5-point scale $(1=$ strongly disagree (SD), $2=$ mildly disagree $(\mathrm{MD}), 3=$ neutral $(\mathrm{N}), 4=$ mildly agree $(\mathrm{MA}), 5=$ strongly agree $(\mathrm{SA})$ ). 


\section{Motivation Item Means}

From the 38 motivations that were identified in the pre-survey, the top and bottom five responses are shown in Table 9 below. The top motivations were "To have fun" $(M=4.48)$ and "To enjoy the company of people who came with me" $(M=4.41)$. The lowest motivations described in this study were "To go somewhere kid friendly" $(M=2.36)$ and "Something to do on vacation" $(M=2.53)$.

Table 9: Maximum and Minimum Motivations Organized by Mean

\begin{tabular}{|c|c|c|c|c|c|c|c|}
\hline & \multicolumn{5}{|c|}{ Percent of Respondents } & \multirow[b]{2}{*}{ Mean } & \multirow[b]{2}{*}{$S D$} \\
\hline & NA & $\mathrm{Li}$ & Mo & $\mathrm{AL}$ & GD & & \\
\hline To have fun & 1.6 & 2.2 & 6.5 & 25.8 & 64.0 & 4.48 & 0.84 \\
\hline $\begin{array}{l}\text { To enjoy the company } \\
\text { of people who came } \\
\text { with me }\end{array}$ & 2.7 & 1.6 & 7.6 & 28.1 & 60.0 & 4.41 & 0.91 \\
\hline To build relationships & 2.7 & 3.8 & 9.7 & 31.4 & 52.4 & 4.27 & 0.97 \\
\hline To be challenged & 3.8 & 3.8 & 13.4 & 26.9 & 52.2 & 4.20 & 1.05 \\
\hline To be outdoors & 3.8 & 3.8 & 11.4 & 31.0 & 50.0 & 4.20 & 1.04 \\
\hline $\begin{array}{l}\text { To check it off my } \\
\text { bucket list }\end{array}$ & 34.8 & 16.6 & 16.6 & 13.4 & 18.7 & 2.65 & 1.53 \\
\hline $\begin{array}{l}\text { To recall past } \\
\text { satisfactions }\end{array}$ & 36.2 & 12.4 & 24.3 & 12.4 & 14.6 & 2.57 & 1.45 \\
\hline To avoid everyday life & 38.2 & 15.6 & 14.0 & 17.2 & 15.1 & 2.55 & 1.51 \\
\hline $\begin{array}{l}\text { Something to do on } \\
\text { vacation }\end{array}$ & 41.4 & 8.6 & 21.0 & 13.4 & 15.6 & 2.53 & 1.51 \\
\hline $\begin{array}{l}\text { To go somewhere kid } \\
\text { friendly }\end{array}$ & 46.2 & 13.0 & 14.1 & 12.0 & 14.7 & 2.36 & 1.51 \\
\hline
\end{tabular}




\section{Activity Information}

This section describes activities the respondents participated during their one-day time period at the OEC. Eighty-eight people participated in the challenge course, the largest number of all participants, accounting for $47.6 \%$ of the total. The canopy tour had 72 survey participants (38.9\%). Only 25 people (13.5\%) did both activities during their single day visit.

\section{Satisfaction Item Means}

Results of the satisfactions section are shown in Table 10 below. With a mean of 4.92 , the overall satisfaction is a good indicator of what is to come. The setting satisfaction "The setting was logical for my experience" had the highest response rate $(M=4.84)$, while "There was adequate signage for my arrival" had the lowest $(M=4.12)$. Next comes facility satisfaction which indicated "I felt safe" to be the top satisfaction $(M=4.86)$ and "The facility was a key part of my experience" at the lowest $(M=4.51)$. Activity satisfaction showed a mean of 4.80 in the "My activity was overall satisfying" question, and a high mean of 4.50 in "My program was challenging”. The next area in the satisfaction section was staff satisfaction. This section was consistently high with the maximum mean being 4.95 under "The staff stayed positive" and the lowest mean of 4.91 under "The staff gave good instructions." The final satisfaction area was that of pre/post logistics. This section looked at setting up the program and paying for it as well. This area had the lowest items overall including the lowest "billing was easy" $(M=4.06)$ Table 10: Satisfaction Organized by Section then Mean

\begin{tabular}{ccccccccc}
\hline & \multicolumn{1}{c}{ Percent of Respondents } & \multicolumn{2}{c}{ Descriptive Statistics } \\
\multicolumn{1}{c}{ Items } & $\mathrm{SD}$ & $\mathrm{MD}$ & $\mathrm{N}$ & $\mathrm{MA}$ & $\mathrm{SA}$ & Mean & $S D$ \\
\hline $\begin{array}{l}\text { Overall Satisfaction } \\
\begin{array}{l}\text { I enjoyed my visit to the Outdoor } \\
\text { Education Center }\end{array}\end{array}$ & 0.0 & 0.0 & 0.0 & 8.1 & 91.9 & 4.92 & 0.28 \\
\hline
\end{tabular}


Table 10: Satisfaction Organized by Section then Mean (continued)

\begin{tabular}{|c|c|c|c|c|c|c|c|}
\hline \multirow[b]{2}{*}{ Items } & \multicolumn{5}{|c|}{ Percent of Respondents } & \multicolumn{2}{|c|}{ Descriptive Statistics } \\
\hline & SD & MD & $\mathrm{N}$ & MA & SA & Mean & $S D$ \\
\hline \multicolumn{8}{|l|}{ Setting Satisfaction } \\
\hline $\begin{array}{l}\text { The setting was logical for my } \\
\text { experience }\end{array}$ & 0.0 & 0.0 & 1.6 & 12.6 & 85.8 & 4.84 & 0.41 \\
\hline $\begin{array}{l}\text { The Setting of the Outdoor Education } \\
\text { Center was acceptable }\end{array}$ & 0.0 & 0.0 & 2.2 & 14.7 & 83.2 & 4.81 & 0.45 \\
\hline $\begin{array}{l}\text { The site was well } \\
\text { maintained/managed }\end{array}$ & 0.5 & 0.0 & 1.6 & 14.1 & 83.7 & 4.80 & 0.51 \\
\hline $\begin{array}{l}\text { The setting was beneficial for my } \\
\text { experience }\end{array}$ & 0.0 & 0.0 & 2.7 & 14.7 & 82.6 & 4.80 & 0.47 \\
\hline $\begin{array}{l}\text { I was pleased with my first } \\
\text { impression of the area }\end{array}$ & 0.0 & 1.6 & 3.2 & 13.0 & 82.2 & 4.76 & 0.59 \\
\hline $\begin{array}{l}\text { There was adequate signage for my } \\
\text { arrival }\end{array}$ & 4.9 & 9.7 & 7.0 & 24.9 & 53.5 & 4.12 & 1.19 \\
\hline \multicolumn{8}{|l|}{ Facility Satisfaction } \\
\hline I felt safe at the facility & 0.0 & 0.0 & 0.5 & 12.9 & 86.6 & 4.86 & 0.36 \\
\hline $\begin{array}{l}\text { I was comfortable during my time at } \\
\text { the OEC }\end{array}$ & 0.0 & 0.0 & 0.0 & 18.9 & 81.1 & 4.81 & 0.39 \\
\hline The facility was operational & 0.0 & 2.2 & 3.2 & 15.6 & 79.0 & 4.72 & 0.63 \\
\hline $\begin{array}{l}\text { I am satisfied with my access to basic } \\
\text { needs }\end{array}$ & 0.0 & 3.2 & 2.2 & 21.1 & 73.5 & 4.65 & 0.68 \\
\hline $\begin{array}{l}\text { The facility was a key part of my } \\
\text { experience }\end{array}$ & 0.0 & 1.6 & 11.4 & 21.6 & 65.4 & 4.51 & 0.76 \\
\hline \multicolumn{8}{|l|}{ Activity Satisfaction } \\
\hline My activity was overall satisfying & 0.0 & 0.0 & 2.2 & 15.7 & 82.2 & 4.80 & 0.45 \\
\hline $\begin{array}{l}\text { My needs were met during the } \\
\text { program }\end{array}$ & 0.0 & 0.0 & 2.7 & 14.7 & 82.6 & 4.80 & 0.47 \\
\hline I was prepared during my program & 0.0 & 0.0 & 2.7 & 18.5 & 78.8 & 4.76 & 0.49 \\
\hline My program was worth the cost & 0.0 & 0.5 & 15.8 & 16.3 & 67.4 & 4.51 & 0.78 \\
\hline My program was challenging & 0.0 & 3.2 & 5.4 & 29.2 & 62.2 & 4.50 & 0.75 \\
\hline
\end{tabular}


Table 10: Satisfaction Organized by Section then Mean (continued)

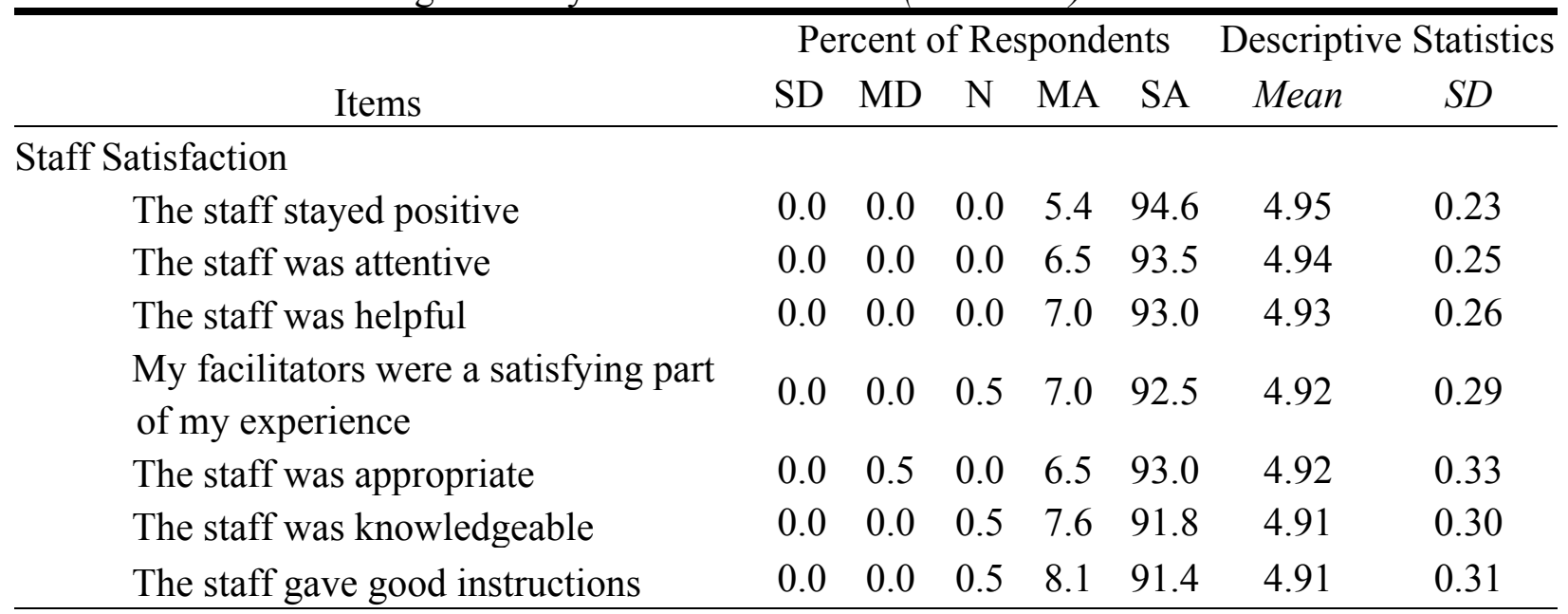

Pre/Post Satisfaction

During this time, the staff was

accommodating

$\begin{array}{lllllll}0.0 & 0.0 & 9.7 & 9.7 & 80.5 & 4.71 & 0.64\end{array}$

I was prepared for my program.

$\begin{array}{lllllll}0.0 & 1.1 & 9.7 & 13.0 & 76.2 & 4.64 & 0.70\end{array}$

The management team was easy to

talk to

$\begin{array}{lllllll}0.0 & 0.0 & 14.1 & 8.7 & 77.2 & 4.63 & 0.72\end{array}$

The pre/post programming logistics

were handled well

$\begin{array}{lllllll}0.0 & 2.7 & 15.3 & 12.6 & 69.4 & 4.49 & 0.85\end{array}$

Scheduling was adequate

$\begin{array}{lllllll}0.6 & 2.2 & 20.4 & 13.8 & 63.0 & 4.36 & 0.92\end{array}$

Billing was easy

$\begin{array}{lllllll}0.6 & 2.2 & 38.0 & 8.9 & 50.3 & 4.06 & 1.01\end{array}$

Note: Items are measured using a 5-point scale ( $1=$ strongly disagree (SD), 2 = mildly disagree $(\mathrm{MD}), 3=$ neutral $(\mathrm{N}), 4=$ mildly agree $(\mathrm{MA}), 5=$ strongly agree $(\mathrm{SA})$ ).

\section{Loyalty Items Means}

At the end of section 4 participants were asked a series of questions pertaining to future visitation and words of mouth. A 5-point scale ranging from Strongly Disagree to Strongly Agree was used in Table 11 below. As seen in Table 11 below, The highest mean came from "I would tell other people positive things about this place" $(M=4.88)$. "I would visit this place again" had the lowest mean of 4.72 . 
Table 11: Loyalty items organized by mean

\begin{tabular}{lccccccccc}
\hline & \multicolumn{3}{c}{ Percent of Respondents } & \multicolumn{4}{c}{$\begin{array}{c}\text { Descriptive } \\
\text { Statistics }\end{array}$} \\
& Items & SD & MD & N & MA & SA & Mean & SD \\
\hline $\begin{array}{l}\text { I would tell other people positive things about } \\
\text { this place. }\end{array}$ & 0.0 & 0.0 & 0.0 & 12.4 & 87.6 & 4.88 & 0.33 \\
I would recommend this place to my friends. & 0.0 & 0.5 & 0.5 & 15.1 & 83.8 & 4.82 & 0.44 \\
$\begin{array}{l}\text { I would recommend this place to people who } \\
\text { seek my advice. }\end{array}$ & 0.0 & 0.5 & 1.6 & 15.7 & 82.2 & 4.79 & 0.48 \\
I would visit this place again. & 0.0 & 1.1 & 4.3 & 16.2 & 78.4 & 4.72 & 0.60 \\
\hline
\end{tabular}

Note: Items are measured using a 5-point scale ( 1 = strongly disagree (SD), 2 = mildly disagree (MD), 3 =neutral (N), $4=$ mildly agree (MA), $5=$ strongly agree (SA)).

\section{Factor Analysis}

Once the descriptive statistics were analyzed, a factor analysis was run for expectations, motivations, satisfactions and loyalty (Table 12-Table 14). Along with these analyses, a KaiserMeyer-Olkin Measure of Sampling Adequacy, Bartlett's Test of Sphericity, and Standardized Cronbach's $\alpha$ were compiled for each analysis, respectively. Initial eigenvalues observed within each analysis were $>1$.

\section{Factor Analysis for Expectation Items}

During the factor analysis on expectations, four factors emerged in the results with eigenvalues $>1$ and Cronbach's $\alpha$ ranging from .87 to .78 . This also resulted in the elimination of three items due to low factor loading.

With a KMO of .89, the expectations had a high adequacy for the factor analysis and Bartlett's Value shows a significance to the null hypothesis with a $p$-value of $<.001$. Thirty expectation items were categorized into four factors, including Factor 1 - Adventure experience, Factor 2 - Cognitive growth, Factor 3 - Outdoor learning and punctuality, and Factor 4 New/nice/safe/memories. Factor 4 enveloped many variable terms that did not constitute a 
simple expression. Looking at the Cronbach's alpha, the first three factors $(\alpha=.87, .82, .86)$ have good consistency, while the third $(\alpha=.78)$ is just below, with an acceptable consistency.

The first factor has a total variance explained of $34.00 \%(M=4.42, S D=0.57)$. The second factor has a variance of $7.75 \%(M=4.10, S D=0.68)$. For the third and fourth factor, total variance is $6.84 \%(M=3.89, S D=0.79)$, and $4.47 \%(M=4.56, S D=0.49)$, respectively. Table 12: Expectation Loadings and Subscales

\begin{tabular}{|c|c|c|c|c|c|c|}
\hline \multirow{2}{*}{$\begin{array}{l}\text { Factor (Proportion): } \\
\text { Scale name \& items }\end{array}$} & \multirow{2}{*}{$M$} & \multirow{2}{*}{$S D$} & \multicolumn{4}{|c|}{ Rotated (varimax) factors } \\
\hline & & & 1 & 2 & 3 & 4 \\
\hline Factor 1: Adventure Experience & 4.42 & 0.57 & & & & \\
\hline Having an adventure & 4.58 & 0.71 & .819 & .220 & .190 & .115 \\
\hline Exciting experience & 4.54 & 0.72 & .71 & .060 & .102 & .462 \\
\hline Experiencing an adrenaline rush & 4.14 & 0.99 & .67 & .312 & .244 & -.001 \\
\hline Having fun & 4.68 & 0.50 & .631 & .176 & .131 & .377 \\
\hline Experiencing exciting activities & 4.50 & 0.70 & .582 & .198 & .176 & .364 \\
\hline Experiencing physical growth & 4.04 & 1.05 & .500 & .446 & .141 & .290 \\
\hline Recreation & 4.43 & 0.79 & .472 & -.081 & .403 & .178 \\
\hline Experiencing friendly service & 4.51 & 0.69 & .436 & .335 & .234 & .059 \\
\hline Factor 2: Cognitive Growth & 4.10 & 0.68 & & & & \\
\hline Experiencing mental growth & 4.17 & 0.89 & .130 & .720 & .009 & .166 \\
\hline Experiencing change & 4.08 & 0.95 & .300 & .693 & .139 & .074 \\
\hline To create meaning & 3.90 & 1.06 & .198 & .669 & .192 & -.003 \\
\hline Gaining knowledge & 4.23 & 0.83 & -.014 & .665 & .369 & .234 \\
\hline Deepening relationship & 4.32 & 0.89 & .119 & .555 & -.104 & .225 \\
\hline Experiencing professionalism & 4.25 & 0.92 & .164 & .468 & .193 & .263 \\
\hline Meeting new people & 3.85 & 1.27 & .222 & .433 & .076 & .133 \\
\hline
\end{tabular}


Table 12: Expectation Loadings and Subscales (continued)

\begin{tabular}{|c|c|c|c|c|c|c|}
\hline \multirow{2}{*}{$\begin{array}{l}\text { Factor (Proportion): } \\
\text { Scale name \& items }\end{array}$} & \multirow{2}{*}{$M$} & \multirow{2}{*}{$S D$} & \multicolumn{4}{|c|}{ Rotated (varimax) factors } \\
\hline & & & 1 & 2 & 3 & 4 \\
\hline $\begin{array}{l}\text { Factor 3: Outdoor Learning \& } \\
\text { Punctuality }\end{array}$ & 3.89 & 0.79 & & & & \\
\hline Learning about the forest & 3.56 & 1.22 & .227 & .161 & .819 & .088 \\
\hline Learning about the zip Line & 3.56 & 1.37 & .236 & -.009 & .775 & .095 \\
\hline Learning about WVU & 3.59 & 1.16 & .040 & .362 & .651 & .085 \\
\hline Seeing scenic beauty & 4.39 & 0.86 & .547 & .134 & .603 & .067 \\
\hline Enjoying the outdoors & 4.50 & 0.73 & .477 & .088 & .490 & .120 \\
\hline Experiencing punctuality & 3.60 & 1.18 & .160 & .272 & .457 & .057 \\
\hline Having a controlled environment & 4.06 & 1.05 & .166 & .380 & .400 & .180 \\
\hline $\begin{array}{l}\text { Factor 4: } \\
\text { New/Safe/Nice/Memories }\end{array}$ & 4.56 & 0.49 & & & & \\
\hline Having a nice event & 4.61 & 0.58 & .164 & .094 & .142 & .803 \\
\hline Enjoying new activities & 4.55 & 0.72 & .242 & .245 & -.054 & .775 \\
\hline Participating in safe activities & 4.46 & 0.77 & .085 & .071 & .167 & .643 \\
\hline Gaining a new experience & 4.52 & 0.75 & .141 & .467 & .092 & .549 \\
\hline Making memories & 4.69 & 0.54 & .294 & .101 & .261 & .435 \\
\hline Eigenvalues & & & 10.199 & 2.324 & 2.053 & 1.341 \\
\hline$\%$ of Variance & & & 33.995 & 7.746 & 6.844 & 4.469 \\
\hline Standardized Cronbach's a - $\alpha$ & & & .87 & .82 & .86 & .78 \\
\hline
\end{tabular}

Note: The sequence of the factors is reordered to be more practically meaningful. As such, it does not make sense to present cumulative variance $(53.05 \%)$ in the table. KMO $=.89$, Bartlett's Test of Sphericity $<.001$. Factor loadings $<.4$ are suppressed.

\section{Factor Analysis for Motivation Items}

As for the motivation item factor analysis, six factors emerged in the results with eigenvalues $>1$ and Cronbach's $\alpha$ ranging from .92 to .68 . One item was eliminated due to its low factor loading on any factor. 
With a KMO of .93, the motivations had a high adequacy for the factor analysis and Bartlett's Value shows a significance to the null hypothesis with a p-value of $<.001$. Thirty-eight motivation items were categorized into six different factors. They are: Factor 1 - Adventure and Learning, Factor 2 -Nature and Outdoors, Factor 3 - Family and Relaxation, Factor 4 Teamwork and Relationship Building, Factor 5 - New Experience, and 6 - Socializing. Per Cronbach's alpha, the first three factors $(\alpha=.92, .92, .89)$ show excellent consistency, and the remaining three $(\alpha=.77, .70, .68)$ acceptable. About $66 \%$ of the variance was explained by these factors.

The first factor explained $39.78 \%$ of the total variance $(M=3.80, S D=0.89)$. The second factor has a variance of $9.78 \%(M=3.87, S D=0.94)$ and for the third factor, total variance is $5.55 \%(M=2.81, S D=1.09)$. The fourth factor has a variance of $4.23 \%(M=3.66, S D=1.01)$. Finally, factor five and factor six explained $3.40 \%(M=3.25, S D=1.17)$, and $3.25 \%(M=4.24$, $S D=0.86)$, of total variance, respectively.

Table 13: Motivation Loadings and Subscales

\begin{tabular}{lccccccccc}
\hline Factor (Proportion): & & & \multicolumn{7}{c}{ Rotated (varimax) factors } \\
Scale name \& items & $M$ & $S D$ & & & 2 & 3 & 4 & 5 & 6 \\
\hline Factor 1: Adventure and Learning & $\mathbf{3 . 8 0}$ & $\mathbf{0 . 8 9}$ & & & & & & \\
& & & & & & & & \\
To push yourself & 4.01 & 1.12 & $\mathbf{. 7 8 8}$ & .201 & .129 & .161 & .182 & .080 \\
To be out of my comfort zone & 3.81 & 1.14 & $\mathbf{. 7 3 8}$ & .113 & .110 & .116 & .435 & -.057 \\
To experience self-discovery & 3.78 & 1.18 & $\mathbf{. 7 2 5}$ & .183 & .223 & .304 & .027 & .101 \\
To be challenged & 4.20 & 1.05 & $\mathbf{. 7 1 5}$ & .207 & .045 & .118 & .029 & .298 \\
To learn & 3.92 & 1.11 & $\mathbf{. 6 5 8}$ & .119 & .255 & .377 & -.230 & .161 \\
To experience something new & 4.15 & 1.12 & $\mathbf{. 6 3 9}$ & .141 & .125 & -.006 & .158 & .066 \\
To enhance self-esteem & 3.55 & 1.37 & $\mathbf{. 6 2 8}$ & .334 & .143 & .275 & .151 & -.041 \\
To be educated & 3.64 & 1.24 & $\mathbf{. 6 0 2}$ & .146 & .291 & .362 & -.247 & .172 \\
To face fear & 3.25 & 1.42 & $\mathbf{. 5 9 2}$ & .117 & .180 & .236 & .491 & -.085
\end{tabular}


Table 13: Motivation Loadings and Subscales (continued)

\begin{tabular}{|c|c|c|c|c|c|c|c|c|}
\hline \multirow{2}{*}{$\begin{array}{l}\text { Factor (Proportion): } \\
\text { Scale name \& items }\end{array}$} & \multirow{2}{*}{$M$} & \multirow{2}{*}{$S D$} & \multicolumn{6}{|c|}{ Rotated (varimax) factors } \\
\hline & & & 1 & 2 & 3 & 4 & 5 & 6 \\
\hline To be adventurous & 4.16 & 1.00 & .533 & .452 & .165 & .006 & .216 & .181 \\
\hline To be safe & 3.44 & 1.43 & .463 & .266 & .417 & .097 & .023 & .073 \\
\hline Factor 2: Nature and Outdoors & 3.87 & 0.94 & & & & & & \\
\hline $\begin{array}{l}\text { To enjoy the smells and sounds of } \\
\text { nature }\end{array}$ & 3.70 & 1.29 & .192 & .831 & .226 & .120 & -.016 & -.067 \\
\hline To be outdoors & 4.20 & 1.04 & .174 & .778 & .246 & -.010 & .106 & .077 \\
\hline To enjoy scenic view & 3.83 & 1.24 & .295 & .763 & .295 & -.038 & .078 & .119 \\
\hline To be close to nature & 3.75 & 1.28 & .299 & .747 & .252 & .253 & .051 & .006 \\
\hline To enjoy nice weather & 3.58 & 1.34 & .041 & .654 & .246 & .289 & .235 & .190 \\
\hline To recreate & 3.63 & 1.33 & .207 & .620 & .208 & .123 & .055 & .257 \\
\hline To explore & 3.94 & 1.15 & .499 & .571 & .232 & .140 & .095 & .216 \\
\hline To have fun & 4.48 & 0.84 & .372 & .546 & .028 & -.119 & .074 & .447 \\
\hline To be entertained & 3.81 & 1.16 & .130 & .512 & .222 & -.059 & .481 & .274 \\
\hline Factor 3: Family and Relaxation & 2.81 & 1.09 & & & & & & \\
\hline To be with family & 2.83 & 1.74 & .096 & .105 & .761 & -.352 & .037 & .183 \\
\hline To go somewhere kid friendly & 2.36 & 1.51 & .248 & .260 & .756 & .070 & .032 & -.040 \\
\hline Something to do on vacation & 2.53 & 1.51 & .289 & .227 & .688 & -.163 & .157 & .005 \\
\hline To do an affordable activity & 3.39 & 1.40 & .165 & .343 & .581 & .094 & .012 & .341 \\
\hline To do something in my free time & 3.11 & 1.50 & .213 & .397 & .566 & -.028 & .350 & .159 \\
\hline To go sightseeing & 3.14 & 1.40 & .053 & .525 & .548 & .049 & .195 & .153 \\
\hline To avoid everyday life & 2.55 & 1.51 & .117 & .262 & .530 & .244 & .247 & .026 \\
\hline To recall past satisfactions & 2.57 & 1.45 & .160 & .399 & .482 & .369 & .136 & -.068 \\
\hline To support local business & 2.91 & 1.43 & .211 & .435 & .448 & .239 & .168 & .171 \\
\hline $\begin{array}{l}\text { Factor 4: Teamwork and } \\
\text { Relationship Building }\end{array}$ & 3.66 & 1.01 & & & & & & \\
\hline To develop Teamwork & 4.08 & 1.28 & .260 & -.077 & -.075 & .832 & .028 & .019 \\
\hline To build relationships & 4.27 & 0.97 & .118 & .126 & -.116 & .809 & .044 & .204 \\
\hline To lead team development & 3.57 & 1.50 & .343 & .109 & .042 & .785 & .044 & -.089 \\
\hline Close to home & 2.69 & 1.55 & -.066 & .217 & .330 & .400 & 0.200 & .311 \\
\hline
\end{tabular}


Table 13: Motivation Loadings and Subscales (continued)

\begin{tabular}{|c|c|c|c|c|c|c|c|c|}
\hline \multirow{2}{*}{$\begin{array}{l}\text { Factor (Proportion): } \\
\text { Scale name \& items }\end{array}$} & \multirow{2}{*}{$M$} & \multirow{2}{*}{$S D$} & \multicolumn{6}{|c|}{ Rotated (varimax) factors } \\
\hline & & & 1 & 2 & 3 & 4 & 5 & 6 \\
\hline Factor 5: New Experience & 3.25 & 1.17 & & & & & & \\
\hline To check it off my bucket list & 2.65 & 1.53 & .235 & .125 & .311 & .132 & .657 & .137 \\
\hline To be thrilled & 3.84 & 1.15 & .461 & .462 & .157 & -.089 & .525 & .162 \\
\hline Factor 6: Socialize & 4.24 & 0.86 & & & & & & \\
\hline $\begin{array}{l}\text { To enjoy the company of people } \\
\text { who came with me }\end{array}$ & 4.41 & 0.91 & .167 & .167 & .176 & .125 & .141 & .788 \\
\hline To be social & 4.08 & 1.08 & .433 & .257 & .037 & .449 & .042 & .477 \\
\hline Eigenvalues & & & 15.116 & 3.715 & 2.107 & 1.607 & 1.293 & 1.231 \\
\hline$\%$ of Variance & & & 39.779 & 9.778 & 5.545 & 4.228 & 3.404 & 3.240 \\
\hline Standardized Cronbach's a $\alpha$ & & & .92 & .92 & .89 & .77 & .70 & .68 \\
\hline
\end{tabular}

Note. The sequence of the factors is reordered to be more practically meaningful. As such, it does not make sense to present cumulative variance $(65.97 \%)$ in the table. KMO $=.93$, Bartlett's Test of Sphericity $<.001$. Factor loadings $<.4$ are suppressed.

\section{Factor Analysis for Satisfaction and Loyalty Items}

In the factor analysis of the satisfaction and loyalty items seven factors emerged in the results with eigenvalues $>1$ and Cronbach's $\alpha$ ranging from .94 to .55 . No items were dropped from this analysis.

With a KMO of .85 , the satisfactions had a high adequacy for the factor analysis and Bartlett's Value shows a significance to the null hypothesis with a p-value of $<.001$. Thirty-four satisfaction items were categorized into seven categories, namely, Factor 1 - Satisfaction with sites and facilities, Factor 2 - Satisfaction with setting, Factor 3 - Satisfaction with signage and impression, Factor 4 - Satisfaction with staff. Factor 5 - Satisfaction with program logistics, Factor 6 - Satisfaction with activities, and Factor 7 - Loyalty. Looking at the Cronbach's alpha, factor $4(\alpha=.94)$ has excellent consistency; factors $1,2,5$, and $7(\alpha=.83, .80, .84, .89)$ have 
good consistency; while the sixth factor $(\alpha=.79)$ is just above an acceptable consistency. Factor 3 has a poor consistency with an $\alpha$ equal to .55 .

The first factor has a total variance explained of $5.79 \%(M=4.73, S D=0.42)$. The second factor has a variance of $4.09 \%(M=4.82, S D=0.37)$. For the third factor, total variance is $3.14 \%(M=4.44, S D=0.78)$, and factor four has a variance of $34.67 \%(M=4.92, S D=0.24)$. Factor five and six have variances of $8.45 \%(M=4.48, S D=0.61)$ and $4.96 \%(M=4.68, S D=$ 0.44). The final factor of satisfaction and loyalty has a variance of $11.04 \%(M=4.83, S D=$ 0.36).

Table 14: Satisfaction and Loyalty Loadings and Subscales

\begin{tabular}{|c|c|c|c|c|c|c|c|c|c|}
\hline \multirow{2}{*}{$\begin{array}{l}\text { Factor } \\
\text { (Proportion): } \\
\text { Scale name \& } \\
\text { items }\end{array}$} & \multirow[b]{2}{*}{$M$} & \multirow[b]{2}{*}{$S D$} & \multicolumn{7}{|c|}{ Rotated (varimax) factors } \\
\hline & & & 1 & 2 & 3 & 4 & 5 & 6 & 7 \\
\hline $\begin{array}{l}\text { Factor 1: } \\
\text { Satisfaction with } \\
\text { sites and facilities }\end{array}$ & 4.73 & 0.42 & & & & & & & \\
\hline $\begin{array}{l}\text { The facility was } \\
\text { operational }\end{array}$ & & & .776 & -.003 & -.115 & .095 & .277 & -.044 & -.038 \\
\hline $\begin{array}{l}\text { I am satisfied with } \\
\text { my access to basic } \\
\text { needs }\end{array}$ & & & .740 & .305 & -.021 & .107 & .200 & .196 & .126 \\
\hline $\begin{array}{l}\text { The facility was a } \\
\text { key part of my } \\
\text { experience }\end{array}$ & & & .716 & -.092 & .303 & -.005 & .176 & .209 & -.002 \\
\hline $\begin{array}{l}\text { I was comfortable } \\
\text { during my time at } \\
\text { the OEC }\end{array}$ & & & .620 & .239 & .096 & .311 & .203 & .142 & .148 \\
\hline $\begin{array}{l}\text { The site was well } \\
\text { maintained/manag } \\
\text { ed }\end{array}$ & & & .572 & .435 & .159 & .274 & -.037 & .068 & .166 \\
\hline $\begin{array}{l}\text { I felt safe at the } \\
\text { facility }\end{array}$ & & & .534 & .030 & .083 & .537 & .018 & .139 & .249 \\
\hline
\end{tabular}


Table 14: Satisfaction and Loyalty Loadings and Subscales (continued)

\begin{tabular}{|c|c|c|c|c|c|c|c|c|c|}
\hline \multirow{2}{*}{$\begin{array}{l}\text { Factor } \\
\text { (Proportion): } \\
\text { Scale name \& } \\
\text { items }\end{array}$} & \multirow[b]{2}{*}{$M$} & \multirow[b]{2}{*}{$S D$} & \multicolumn{7}{|c|}{ Rotated (varimax) factors } \\
\hline & & & 1 & 2 & 3 & 4 & 5 & 6 & 7 \\
\hline
\end{tabular}

Factor 2:

Satisfaction with setting

The setting was beneficial for my experience

The setting was logical for my experience The Setting of the Outdoor Education Center was

\section{$\begin{array}{ll}4.82 & 0.37\end{array}$}

acceptable

\section{Factor 3:}

Satisfaction with signage and

\section{$\begin{array}{ll}4.44 & 0.78\end{array}$}

$\begin{array}{lllllll}.127 & .748 & .138 & .231 & .217 & .243 & .220\end{array}$

$\begin{array}{lllllll}.241 & .658 & .066 & .394 & .175 & .160 & .170\end{array}$ impression

There was

adequate signage

$\begin{array}{lllllll}.093 & .036 & .829 & .016 & .140 & .045 & .127\end{array}$

for my arrival

I was pleased with

my first

impression of the

$\begin{array}{lllllll}.331 & .404 & .234 & .348 & .226 & .303 & .131\end{array}$

area

Factor 4:

Satisfaction with $\quad 4.92 \quad 0.24$

staff

The staff stayed positive

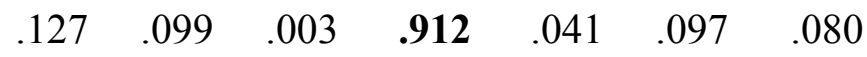

My facilitators

were a satisfying

part of my

$\begin{array}{lllllll}.114 & .211 & .703 & .293 & -.024 & .135 & .263\end{array}$

experience

The staff was

attentive

$\begin{array}{lllllll}.113 & -.053 & .063 & \mathbf{8 6 5} & .052 & .155 & .137\end{array}$


Table 14: Satisfaction and Loyalty Loadings and Subscales (continued)

\begin{tabular}{|c|c|c|c|c|c|c|c|c|c|}
\hline \multirow{2}{*}{$\begin{array}{l}\text { Factor } \\
\text { (Proportion): } \\
\text { Scale name \& } \\
\text { items }\end{array}$} & \multirow[b]{2}{*}{$M$} & \multirow[b]{2}{*}{$S D$} & \multicolumn{7}{|c|}{ Rotated (varimax) factors } \\
\hline & & & 1 & 2 & 3 & 4 & 5 & 6 & 7 \\
\hline $\begin{array}{l}\text { The staff was } \\
\text { knowledgeable }\end{array}$ & & & .058 & .134 & .243 & .853 & .069 & .128 & .109 \\
\hline $\begin{array}{l}\text { The staff gave } \\
\text { good instructions }\end{array}$ & & & .079 & .229 & -.021 & .851 & .153 & .194 & .058 \\
\hline $\begin{array}{l}\text { The staff was } \\
\text { appropriate }\end{array}$ & & & .113 & .000 & -.085 & .845 & .154 & .139 & .079 \\
\hline $\begin{array}{l}\text { The staff was } \\
\text { helpful }\end{array}$ & & & .075 & .203 & .022 & .826 & .097 & .070 & .084 \\
\hline
\end{tabular}

\section{Factor 5:}

Satisfaction with $\quad 4.48 \quad 0.61$

program logistics

Scheduling was

adequate

$\begin{array}{lllllll}.024 & .020 & .153 & .001 & .752 & .212 & .166\end{array}$

The pre/post

programming

logistics were

$\begin{array}{lllllll}-.001 & .153 & .183 & .049 & .751 & .056 & .103\end{array}$

handled well

I was prepared for

my program.

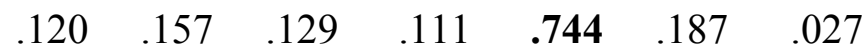

During this time,

the staff was

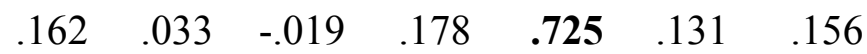

accommodating

The management

team was easy to

$\begin{array}{lllllll}.274 & .042 & -.050 & .126 & \mathbf{7 1 0} & -.042 & .227\end{array}$

talk to

Billing was easy

$\begin{array}{lllllll}.207 & .008 & -.177 & .047 & \mathbf{6 8 1} & .085 & -.025\end{array}$

\section{Factor 6:}

Satisfaction with $\quad 4.68 \quad 0.44$

activities

My activity was

overall satisfying

$\begin{array}{lllllll}-.042 & .089 & .011 & .276 & .171 & .782 & .155 \\ .191 & -.060 & .126 & .031 & -.006 & .748 & .249\end{array}$

My program was

challenging

$\begin{array}{lllllll}.191 & -.060 & .126 & .031 & -.006 & .748 & .249\end{array}$ 
Table 14: Satisfaction and Loyalty Loadings and Subscales (continued)

\begin{tabular}{|c|c|c|c|c|c|c|c|c|c|}
\hline \multirow{2}{*}{$\begin{array}{l}\text { Factor } \\
\text { (Proportion): } \\
\text { Scale name \& } \\
\text { items }\end{array}$} & \multirow[b]{2}{*}{$M$} & \multirow[b]{2}{*}{$S D$} & \multicolumn{7}{|c|}{ Rotated (varimax) factors } \\
\hline & & & 1 & 2 & 3 & 4 & 5 & 6 & 7 \\
\hline $\begin{array}{l}\text { My needs were } \\
\text { met during the } \\
\text { program }\end{array}$ & & & .071 & .169 & .200 & .253 & .151 & .705 & .248 \\
\hline $\begin{array}{l}\text { I was prepared } \\
\text { during my } \\
\text { program }\end{array}$ & & & .186 & .174 & .021 & .240 & .253 & .658 & .044 \\
\hline $\begin{array}{l}\text { My program was } \\
\text { worth the cost }\end{array}$ & & & .180 & .288 & -.153 & .128 & .223 & .549 & .223 \\
\hline $\begin{array}{l}\text { Factor 7: Loyalty } \\
\text { I would } \\
\text { recommend this } \\
\text { place to my } \\
\text { friends. }\end{array}$ & 4.83 & 0.36 & .108 & .150 & .096 & .038 & .179 & .130 & .908 \\
\hline $\begin{array}{l}\text { I would } \\
\text { recommend this }\end{array}$ & & & & & & & & & \\
\hline $\begin{array}{l}\text { place to people } \\
\text { who seek my } \\
\text { advice. }\end{array}$ & & & .112 & .174 & .111 & .126 & .162 & .135 & .881 \\
\hline $\begin{array}{l}\text { I would tell other } \\
\text { people positive } \\
\text { things about this } \\
\text { place. }\end{array}$ & & & .073 & .210 & -.066 & .207 & .079 & .089 & .838 \\
\hline $\begin{array}{l}\text { I would visit this } \\
\text { place again. }\end{array}$ & & & .017 & -.036 & .216 & .016 & .104 & .181 & .788 \\
\hline $\begin{array}{l}\text { I enjoyed my visit } \\
\text { to the Outdoor }\end{array}$ & & & .032 & -.027 & .076 & .211 & .094 & .237 & .706 \\
\hline Education Center & & & & & & & & & \\
\hline Eigenvalues & & & 1.97 & 1.39 & 1.07 & 11.78 & 2.87 & 1.69 & 3.75 \\
\hline$\%$ of variance & & & 5.79 & 4.09 & 3.14 & 34.67 & 8.45 & 4.96 & 11.04 \\
\hline $\begin{array}{l}\text { Standardized } \\
\text { Cronbach a's } \alpha\end{array}$ & & & .83 & .80 & .55 & .94 & .84 & .79 & .89 \\
\hline
\end{tabular}

Note. The sequence of the factors is reordered to be more practically meaningful. As such, it does not make sense to present cumulative variance $(72.13 \%)$ in the table. $\mathrm{KMO}=.85$, Bartlett's Test of Sphericity $<.001$. Factor loadings $<.4$ are suppressed. 


\section{Factor Mean Comparisons}

Once the factors were established, SPSS was used to compute the means of the factors.

Individual samples t-tests were then used to compare these means amongst various user groups.

The groups were: Return guest or First-Time visitor, Male or Female, and Program Contact or

Regular Participant, respectively. The t-test results are presented in Table 15-17.

Table 15: Return Guests and First Time Guest Factor Mean Comparison

t-test for Equality of Means

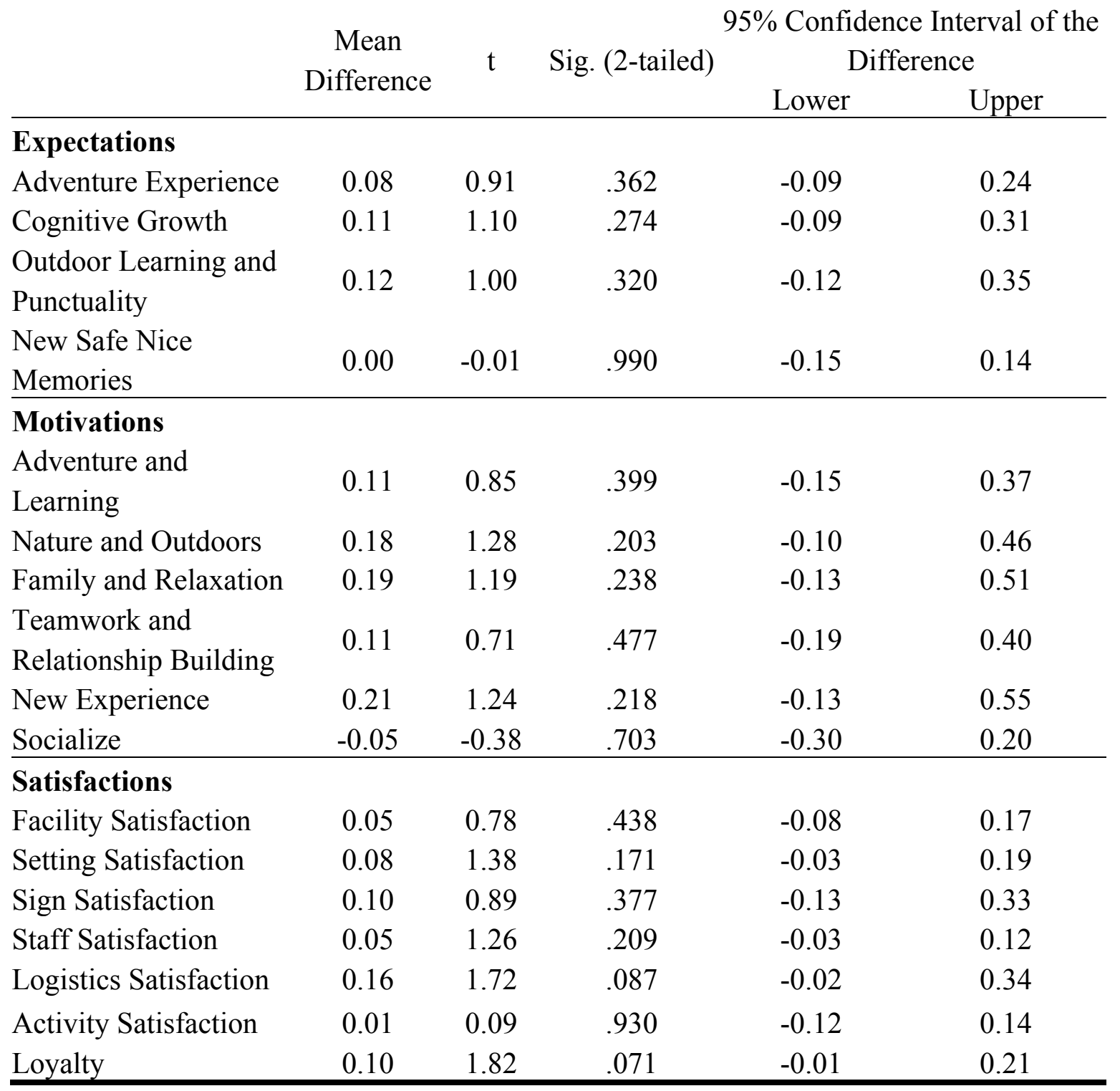


Table 16: Male and female factor mean comparison

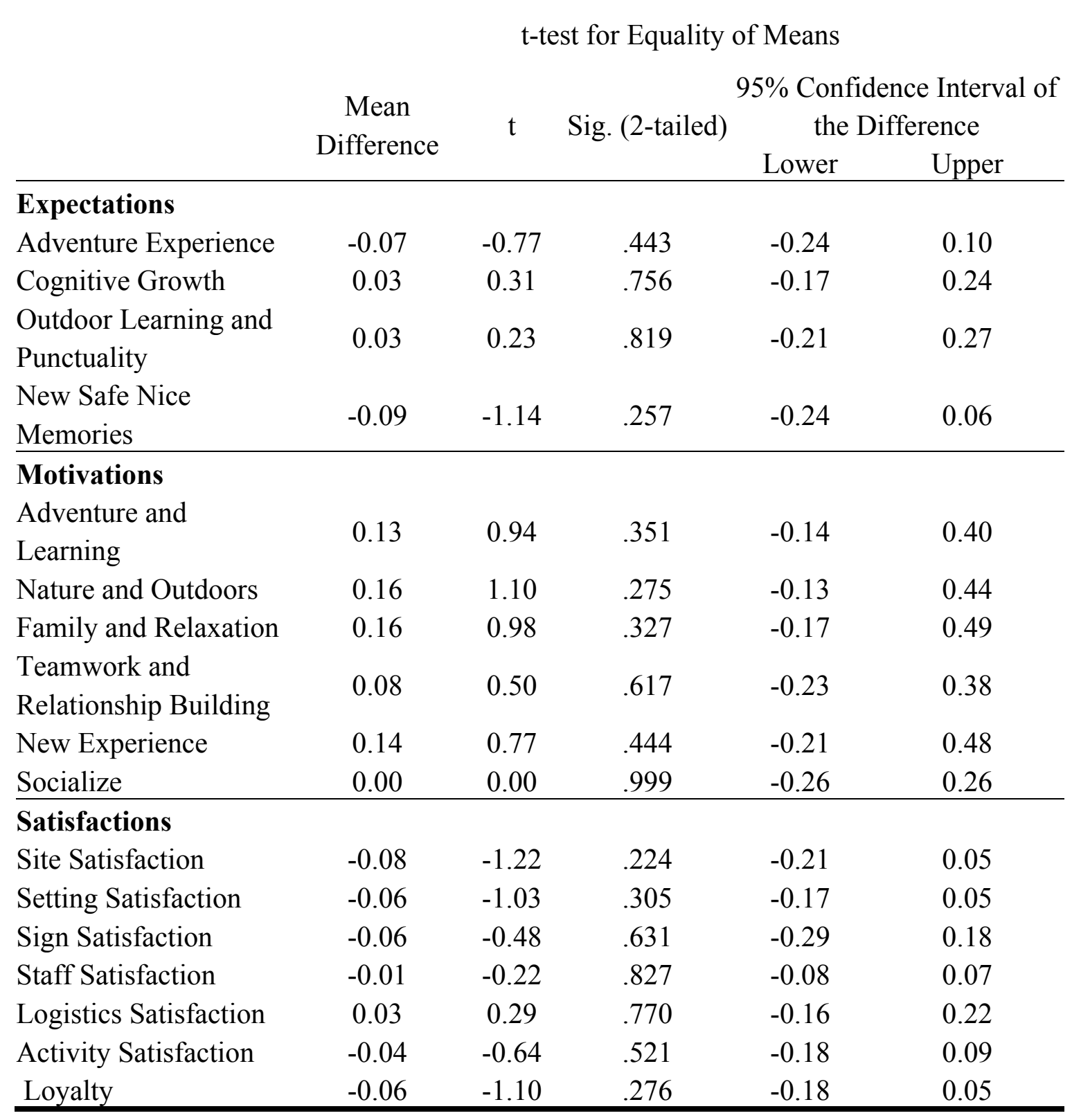


Table 17: Program contact and non-program contacts factor mean comparison

t-test for Equality of Means

\begin{tabular}{|c|c|c|c|c|c|}
\hline & \multirow{2}{*}{$\begin{array}{c}\text { Mean } \\
\text { Difference }\end{array}$} & \multirow[t]{2}{*}{$\mathrm{t}$} & \multirow[t]{2}{*}{ Sig. (2-tailed) } & \multicolumn{2}{|c|}{$\begin{array}{l}\text { 95\% Confidence Interval of the } \\
\text { Difference }\end{array}$} \\
\hline & & & & Lower & Upper \\
\hline \multicolumn{6}{|l|}{ Expectations } \\
\hline Adventure Experience & 0.12 & 1.33 & .187 & -0.06 & 0.30 \\
\hline Cognitive Growth & 0.05 & 0.46 & .646 & -0.16 & 0.26 \\
\hline $\begin{array}{l}\text { Outdoor Learning and } \\
\text { Punctuality }\end{array}$ & $0.34 *$ & 2.78 & .006 & 0.10 & 0.59 \\
\hline $\begin{array}{l}\text { New Safe Nice } \\
\text { Memories }\end{array}$ & -0.01 & -0.18 & .854 & -0.17 & 0.14 \\
\hline \multicolumn{6}{|l|}{ Motivations } \\
\hline $\begin{array}{l}\text { Adventure and } \\
\text { Learning }\end{array}$ & 0.12 & 0.86 & .390 & -0.16 & 0.40 \\
\hline Nature and Outdoors & $0.37^{*}$ & 2.87 & .005 & 0.11 & 0.62 \\
\hline Family and Relaxation & $0.46^{*}$ & 2.97 & .003 & 0.15 & 0.76 \\
\hline $\begin{array}{l}\text { Teamwork and } \\
\text { Relationship Building }\end{array}$ & -0.27 & -1.72 & .087 & -0.59 & 0.04 \\
\hline New Experience & -0.25 & -1.43 & .154 & -0.60 & 0.10 \\
\hline Socialize & 0.21 & 1.73 & .086 & -0.03 & 0.45 \\
\hline \multicolumn{6}{|l|}{ Satisfactions } \\
\hline Facility Satisfaction & $0.18^{*}$ & 3.19 & .002 & 0.07 & 0.29 \\
\hline Setting Satisfaction & $0.16^{*}$ & 3.40 & .001 & 0.07 & 0.26 \\
\hline Sign Satisfaction & -0.03 & -0.22 & .829 & -0.27 & 0.21 \\
\hline Staff Satisfaction & $0.09 *$ & 2.89 & .004 & 0.03 & 0.14 \\
\hline Logistics Satisfaction & $0.46 * *$ & 5.77 & .000 & 0.30 & 0.62 \\
\hline Activity Satisfaction & $0.22 * *$ & 3.49 & .001 & 0.10 & 0.34 \\
\hline Loyalty & $0.19 * *$ & 4.14 & .000 & 0.09 & 0.26 \\
\hline
\end{tabular}

When looking at expectations, motivations, satisfaction and loyalty, significant

differences were found only when comparing the program contacts and the regular participants.

In the expectation category, one significant difference was seen in the factor of Outdoor

Learning and Punctuality. Switching to the motivation category, the factors of Nature and

Outdoors and Family and Relaxation came out significantly different. Within satisfactions and 
loyalty, all factors but sign satisfaction were significantly different at the .005 level including loyalty.

Considering a t-test is only valid when comparing two factors, an Analysis of variance (ANOVA) test was conducted to determine if there were any significant differences in the participants on the canopy tour, challenge course, or those that did both. A post-hoc Least Significant Difference (LSD) test was then recorded to find any significant differences between two categories within the three, i.e. canopy tour and challenge course, or canopy tour and both activities in the same day. These tests can be seen in the Table 18, below.

Table 18: Which Activity Did You Participate In? - ANOVA Post-Hoc LSD

\begin{tabular}{|c|c|c|c|c|c|c|c|}
\hline & \multirow{2}{*}{$\begin{array}{c}\text { (I) } \\
\text { Groups }\end{array}$} & \multirow{2}{*}{$\begin{array}{c}(\mathrm{J}) \\
\text { Groups }\end{array}$} & \multirow{2}{*}{$\begin{array}{c}\text { Mean } \\
\text { Difference } \\
(\mathrm{I}-\mathrm{J})\end{array}$} & \multirow{2}{*}{$\begin{array}{l}\text { Std. } \\
\text { Error }\end{array}$} & \multirow{2}{*}{ Sig. } & \multicolumn{2}{|c|}{$\begin{array}{l}95 \% \text { Confidence } \\
\text { Interval }\end{array}$} \\
\hline & & & & & & $\begin{array}{l}\text { Lower } \\
\text { Bound }\end{array}$ & $\begin{array}{l}\text { Upper } \\
\text { Bound }\end{array}$ \\
\hline \multicolumn{8}{|l|}{ Expectations } \\
\hline \multirow[t]{3}{*}{$\begin{array}{l}\text { Adventure } \\
\text { Experience }\end{array}$} & \multirow[t]{2}{*}{ Canopy Tour } & $\begin{array}{c}\text { Challenge } \\
\text { Course }\end{array}$ & $0.29^{* *}$ & 0.09 & .002 & 0.11 & 0.46 \\
\hline & & Both & 0.05 & 0.13 & .707 & -0.21 & 0.31 \\
\hline & Challenge Course & Both & -0.24 & 0.13 & .065 & -0.40 & 0.02 \\
\hline \multirow[t]{3}{*}{ Cognitive Growth } & \multirow[t]{2}{*}{ Canopy Tour } & $\begin{array}{c}\text { Challenge } \\
\text { Course }\end{array}$ & -0.11 & 0.11 & .323 & -0.32 & 0.11 \\
\hline & & Both & -0.15 & 0.16 & .367 & -0.46 & 0.17 \\
\hline & Challenge Course & Both & -0.04 & 0.16 & .812 & -0.35 & 0.27 \\
\hline \multirow[t]{3}{*}{$\begin{array}{l}\text { Outdoor Learning } \\
\text { and Punctuality }\end{array}$} & \multirow[t]{2}{*}{ Canopy Tour } & $\begin{array}{c}\text { Challenge } \\
\text { Course } \\
\end{array}$ & $0.78^{* * *}$ & 0.11 & .000 & 0.55 & 1.00 \\
\hline & & Both & 0.05 & 0.17 & .749 & -0.27 & 0.38 \\
\hline & Challenge Course & Both & $-0.72^{* * *}$ & 0.16 & .000 & -1.04 & -0.41 \\
\hline \multirow[t]{3}{*}{$\begin{array}{l}\text { New Safe Nice } \\
\text { Memories }\end{array}$} & \multirow[t]{2}{*}{ Canopy Tour } & $\begin{array}{c}\text { Challenge } \\
\text { Course }\end{array}$ & 0.06 & 0.08 & .467 & -0.10 & 0.22 \\
\hline & & Both & -0.11 & 0.12 & .341 & -0.34 & 0.12 \\
\hline & Challenge Course & Both & -0.17 & 0.11 & .138 & -0.40 & 0.06 \\
\hline
\end{tabular}


Table 18: Which Activity Did You Participate In? - ANOVA Post-Hoc LSD (continued)

\begin{tabular}{|c|c|c|c|c|c|c|c|}
\hline & \multirow{2}{*}{$\begin{array}{c}\text { (I) } \\
\text { Groups }\end{array}$} & \multirow{2}{*}{$\begin{array}{c}(\mathrm{J}) \\
\text { Groups }\end{array}$} & \multirow{2}{*}{$\begin{array}{c}\text { Mean } \\
\text { Difference } \\
(\mathrm{I}-\mathrm{J})\end{array}$} & \multirow{2}{*}{$\begin{array}{l}\text { Std. } \\
\text { Error }\end{array}$} & \multirow{2}{*}{ Sig. } & \multicolumn{2}{|c|}{$\begin{array}{l}95 \% \text { Confidence } \\
\text { Interval }\end{array}$} \\
\hline & & & & & & $\begin{array}{l}\text { Lower } \\
\text { Bound }\end{array}$ & $\begin{array}{l}\text { Upper } \\
\text { Bound }\end{array}$ \\
\hline \multicolumn{8}{|l|}{ Motivations } \\
\hline \multirow[t]{3}{*}{$\begin{array}{l}\text { Adventure and } \\
\text { Learning }\end{array}$} & \multirow[t]{2}{*}{ Canopy Tour } & $\begin{array}{l}\text { Challenge } \\
\text { Course }\end{array}$ & 0.03 & 0.15 & .821 & -.025 & 0.32 \\
\hline & & Both & 0.00 & 0.21 & .982 & -0.42 & 0.42 \\
\hline & Challenge Course & Both & -0.03 & 0.21 & .893 & -0.44 & 0.38 \\
\hline \multirow[t]{3}{*}{ Nature and Outdoors } & \multirow[t]{2}{*}{ Canopy Tour } & $\begin{array}{c}\text { Challenge } \\
\text { Course }\end{array}$ & $0.59 * * *$ & 0.15 & .000 & 0.30 & 0.88 \\
\hline & & Both & -0.04 & 0.21 & .849 & -0.46 & 0.38 \\
\hline & Challenge Course & Both & $-0.63 *$ & 0.20 & .002 & -1.03 & -0.23 \\
\hline \multirow[t]{3}{*}{$\begin{array}{l}\text { Family and } \\
\text { Relaxation }\end{array}$} & \multirow[t]{2}{*}{ Canopy Tour } & $\begin{array}{c}\text { Challenge } \\
\text { Course }\end{array}$ & $0.79 * * *$ & 0.17 & .000 & 0.46 & 1.11 \\
\hline & & Both & 0.16 & 0.25 & .507 & -0.32 & 0.65 \\
\hline & Challenge Course & Both & $-0.62 *$ & 0.24 & .011 & -1.10 & -0.15 \\
\hline \multirow{3}{*}{$\begin{array}{l}\text { Teamwork and } \\
\text { Relationship } \\
\text { Building }\end{array}$} & \multirow[t]{2}{*}{ Canopy Tour } & $\begin{array}{c}\text { Challenge } \\
\text { Course }\end{array}$ & $-0.53 * *$ & 0.16 & .001 & -0.84 & -0.22 \\
\hline & & Both & $-0.58^{*}$ & 0.23 & .013 & -1.04 & -0.13 \\
\hline & Challenge Course & Both & -0.06 & 0.23 & .806 & -0.50 & 0.39 \\
\hline \multirow[t]{3}{*}{ New Experience } & \multirow[t]{2}{*}{ Canopy Tour } & $\begin{array}{c}\text { Challenge } \\
\text { Course }\end{array}$ & $0.64 * *$ & 0.18 & .001 & 0.28 & 1.00 \\
\hline & & Both & 0.16 & 0.27 & .557 & -0.37 & 0.68 \\
\hline & Challenge Course & Both & -0.48 & 0.26 & .064 & -0.99 & 0.03 \\
\hline \multirow[t]{3}{*}{ Socialize } & \multirow[t]{2}{*}{ Canopy Tour } & $\begin{array}{l}\text { Challenge } \\
\text { Course }\end{array}$ & -0.04 & 0.14 & .749 & -0.32 & 0.23 \\
\hline & & Both & -0.05 & 0.20 & .809 & -0.45 & 0.35 \\
\hline & Challenge Course & Both & 0.00 & 0.20 & .983 & -0.40 & 0.39 \\
\hline \multicolumn{8}{|l|}{ Satisfactions } \\
\hline \multirow[t]{3}{*}{ Site Satisfaction } & \multirow[t]{2}{*}{ Canopy Tour } & $\begin{array}{l}\text { Challenge } \\
\text { Course }\end{array}$ & $0.21^{* *}$ & 0.07 & .002 & 0.07 & 0.34 \\
\hline & & Both & 0.13 & 0.10 & .173 & -0.06 & 0.33 \\
\hline & Challenge Course & Both & -0.07 & 0.10 & .450 & -0.26 & 0.12 \\
\hline \multirow[t]{3}{*}{ Setting Satisfaction } & \multirow[t]{2}{*}{ Canopy Tour } & $\begin{array}{l}\text { Challenge } \\
\text { Course }\end{array}$ & $0.15^{*}$ & 0.06 & .010 & 0.04 & 0.27 \\
\hline & & Both & $0.21^{*}$ & 0.09 & .014 & 0.04 & 0.38 \\
\hline & Challenge Course & Both & 0.06 & 0.08 & .495 & -0.11 & 0.22 \\
\hline
\end{tabular}


Table 18: Which Activity Did You Participate In? - ANOVA Post-Hoc LSD (continued)

\begin{tabular}{|c|c|c|c|c|c|c|c|}
\hline & (I) & $(\mathrm{J})$ & Mean & Std. & & $\begin{array}{r}95 \% \mathrm{Cc} \\
\text { Int }\end{array}$ & $\begin{array}{l}\text { fidence } \\
\text { val }\end{array}$ \\
\hline & Groups & Groups & $\begin{array}{c}\text { Difference } \\
\text { (I-J) }\end{array}$ & Error & Sig. & $\begin{array}{l}\text { Lower } \\
\text { Bound }\end{array}$ & $\begin{array}{l}\text { Upper } \\
\text { Bound }\end{array}$ \\
\hline \multirow[t]{3}{*}{ Sign Satisfaction } & \multirow[t]{2}{*}{ Canopy Tour } & $\begin{array}{c}\text { Challenge } \\
\text { Course }\end{array}$ & -0.21 & 0.12 & .095 & -0.45 & 0.04 \\
\hline & & Both & -0.06 & 0.18 & .752 & -0.41 & 0.30 \\
\hline & Challenge Course & Both & 0.15 & 0.18 & 391 & -0.20 & 0.50 \\
\hline \multirow[t]{3}{*}{ Staff Satisfaction } & \multirow[t]{2}{*}{ Canopy Tour } & $\begin{array}{c}\text { Challenge } \\
\text { Course }\end{array}$ & $0.09^{*}$ & 0.04 & .023 & 0.01 & 0.17 \\
\hline & & Both & 0.08 & 0.06 & .164 & -0.03 & 0.19 \\
\hline & Challenge Course & Both & -0.01 & 0.05 & .840 & -0.12 & 0.10 \\
\hline \multirow[t]{3}{*}{$\begin{array}{l}\text { Program Logistics } \\
\text { Satisfaction }\end{array}$} & \multirow[t]{2}{*}{ Canopy Tour } & $\begin{array}{c}\text { Challenge } \\
\text { Course }\end{array}$ & $0.40^{* * *}$ & 0.10 & .000 & 0.21 & 0.58 \\
\hline & & Both & 0.28 & 0.14 & .053 & 0.00 & 0.56 \\
\hline & Challenge Course & Both & -0.11 & 0.14 & 417 & -0.39 & 0.16 \\
\hline \multirow[t]{3}{*}{ Activity Satisfaction } & \multirow[t]{2}{*}{ Canopy Tour } & $\begin{array}{c}\text { Challenge } \\
\text { Course }\end{array}$ & 0.07 & 0.07 & .319 & -0.07 & 0.21 \\
\hline & & Both & 0.10 & 0.11 & .339 & -0.11 & 0.31 \\
\hline & Challenge Course & Both & 0.03 & 0.10 & .777 & -0.17 & 0.23 \\
\hline \multirow[t]{3}{*}{ Loyalty } & \multirow[t]{2}{*}{ Canopy Tour } & $\begin{array}{c}\text { Challenge } \\
\text { Course }\end{array}$ & -0.02 & 0.06 & .796 & -0.13 & 0.10 \\
\hline & & Both & -0.03 & 0.08 & .719 & -0.20 & 0.14 \\
\hline & Challenge Course & Both & -0.02 & 0.08 & .852 & -0.18 & 0.15 \\
\hline
\end{tabular}
${ }^{*} \mathrm{p}<.05 ; * * \mathrm{p}<.01 ; * * \mathrm{p}<.001$.

Table 18 shows expectations were significantly different in the factors of Adventure Experience and Outdoor Learning and Punctuality. These two means were significantly higher when the canopy tour was involved in the experience.

While looking at the motivations between activities there were significant differences in all factors except socializing and Adventure and Learning. Experiences containing the canopy tour rated the factors of Nature and Outdoors and Family and Relaxation significantly higher than the challenge course alone. Experiences that provided a challenge course element, were 
motivated by teamwork and relationship building significantly higher than those with just a canopy tour. In terms of a new experience, canopy tour participants indicated a significantly higher motivation because of a new experience.

Observing satisfactions, there were significant differences in program logistics, staff, setting and facility satisfaction. There was not a significant difference in the signage, activity and loyalty. Canopy tour participants rated their program logistics and setting satisfactions significantly higher than participants that had any sort of challenge course experience. Participants that participated in just the canopy tour rated the facility and staff satisfaction significantly higher than those who had just the challenge course experience.

\section{Structural Equation Model}

Ideally, all the latent variables (four for expectations, six for motivations, seven for satisfaction and loyalty) can be included in the SEM. However, this attempt was not successful because the model would be too complex to be analyzed by the software. To make a compromise, one expectation (e.g., adventure experience), one motivation variable (e.g., adventure and learning), two attribute satisfaction variables (e.g., satisfaction with activities and satisfaction with staff) are analyzed along with the overall satisfaction and loyalty variables. Figure 3 presents the results. The $p$ value of greater than .05 is an index to indicate the acceptance of a model. However, the $p$ value is very likely to be less than .05 because $\chi^{2}$ value is sensitive to sample size and model complexity, resulting in the rejection of a well-fitting model (Anderson \& Gerbing, 1988). Alternatively, the ratio of $\chi^{2}$ value over the degree of freedom as high as 5 is acceptable (Wheaton, Muthen, Alwin, \& Summers, 1977) is recommended as a practical index to assess model fit. 
Other assessment indices include RMSEA (Root Mean Square Error of Approximation), CFI (Comparative Fit Index), IFI (Incremental Fit Index), NFI (Normed-Fit Index), and TLI (Tucker-Lewis Index). A RMSEA in the range of .05 to .10 indicates a fair fit and above $.10 \mathrm{a}$ poor fit (MacCallum, Browne, \& Sugawara, 1996), the cut-off criterion for each CFI, IFI, NFI, and TLI is .90. However, 95 is also recommended as the threshold for better fit (Hooper, Coughlan, \& Mullen, 2008).

As shown, the $p$ value for the model is less than .05, as reported in many other studies (e.g., Chen \& Tsai, 2007; Chi \& Qu, 2008; Deng et al., 2010; Hsu et al., 2010; Huang \& Hsu, 2009). However, other indices perform well with the ratios between $\chi^{2}$ value over the degree of freedom being $2.1<5.0$, RMSEA .08 $<.10$. 


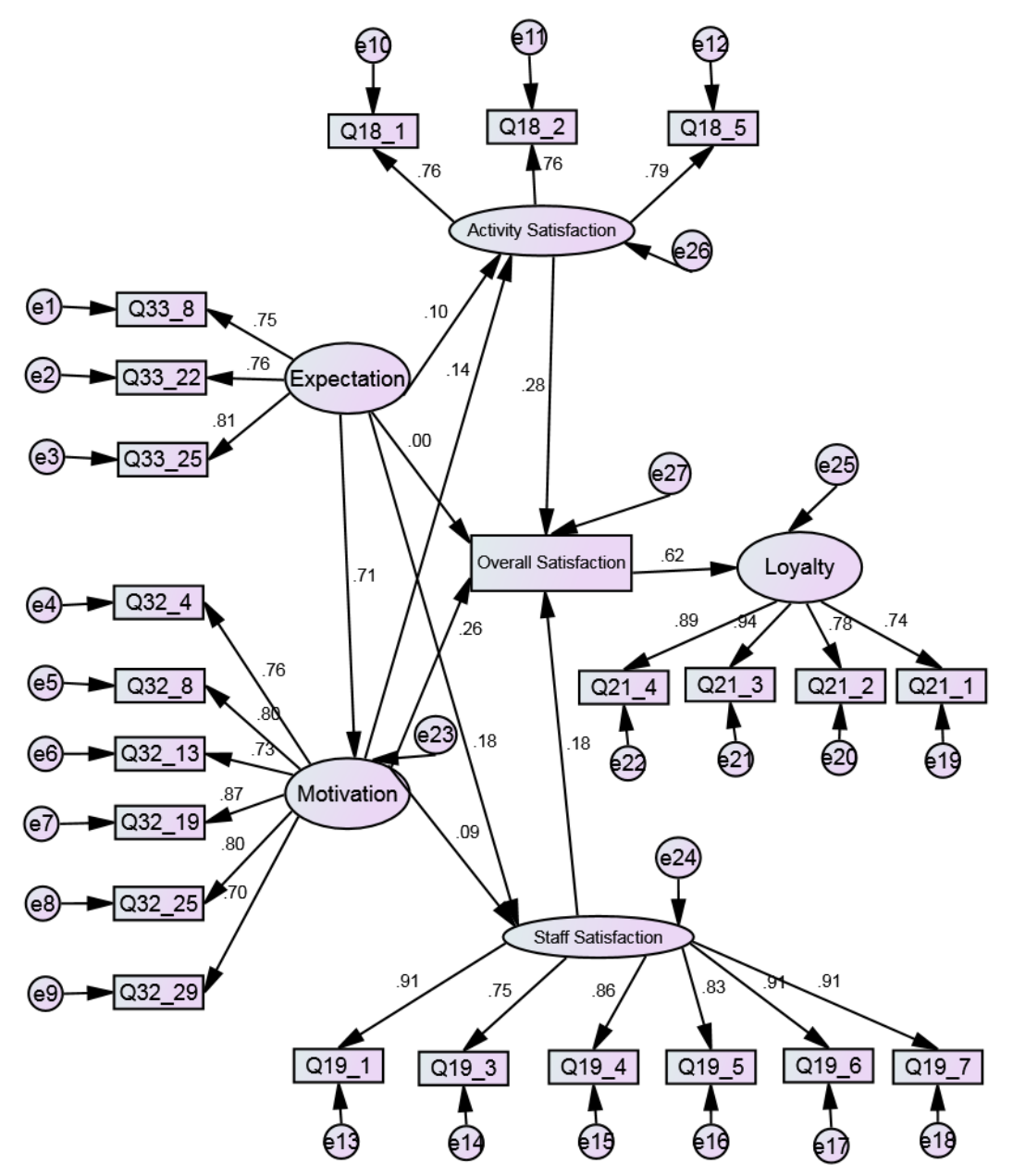

Figure 3: Structural Equation Model (SEM)

In addition, the statistics for other indices are close or beyond $.90(\mathrm{CFI}=.92, \mathrm{IFI}=92$, $\mathrm{NFI}=.86$, and TCL $=.90$ ). These findings indicate the data, after removing several measurement items, fits the model well.

The model shows that expectation significantly and positively correlates with motivation $(p<$ .001). Thus, hypothesis 1: The higher expectations participants have, the more motivated they will be is supported. In addition, both satisfaction with activities $(p<.001)$ and satisfaction with staff $(p<.01)$ are significantly and positively related to overall satisfaction, which, in turn, 
significantly and positively predicts loyalty $(p<.001)$, supporting hypothesis 8 : Satisfaction with activities will significantly contribute to overall satisfaction, hypothesis 9: Satisfaction with staff/facilitators will significantly contribute to overall satisfaction, and hypothesis 10 :

Participants who are more satisfied overall will be more loyal to the OEC. In addition, motivation significantly and positively correlates with overall satisfaction, suggesting hypothesis 7: A higher level of motivation will lead to a higher level of overall satisfaction is also supported. However, neither expectation nor motivation significantly contributes to the two attribute satisfaction, though the relationship is positive. Thus, the following four hypotheses are not supported:

Hypothesis 2: Participants with a higher level of expectation will be more satisfied with their activities at the OEC.

Hypothesis 3: Participants with a higher level of expectation will be more satisfied with OEC staff/facilitators.

Hypothesis 4: Participants with a higher level of motivation will be more satisfied with their activities at the OEC.

Hypothesis 5: Participants with a higher level of motivation will be more satisfied with OEC staff/facilitators.

Finally, expectation was not significantly and positively related to overall satisfaction, resulting in the rejection of hypothesis 6: A higher level of expectation will lead to a higher level of overall satisfaction. 


\section{CHAPTER 5: DISCUSSION}

The purpose of this section is to describe the relationship between expectations, motivations, satisfaction and return visitation in outdoor adventure areas such as the WVU OEC, using canopy zip line tours and challenge course products. Previous research considered these constructs as they related to outdoor recreation as a whole. There has not been an abundance of information that considers canopy tours or challenge courses to this extent.

The following chapter includes discussion of the research questions and a discussion of the structural equation model.

\section{Discussion of Research Questions}

\section{RQ1: What are the expectations of visiting the WVU OEC?}

The highest expectation items of a program at the OEC were making memories, having fun and having a nice event. The lowest items in the expectation category were feeling pressure, having large groups and learning about the zip line

The highest factor mean of the expectations came from making memories, followed by Adventure Experience, whereas the lowest mean came from Factor 3 - Outdoor Learning and Punctuality. Enjoying the outdoors was classified in this category, but had the $6^{\text {th }}$ highest mean of 4.50. This could suggest most people were not expecting learning about the outdoors or a sense of punctuality. Maybe suggesting most people did not have a set schedule. Overall, the factor of (1) Adventure Experience accounted for the most variance within this sample.

\section{RQ2: What are the Motivations of visiting the WVU OEC?}

The number one motivation to go to the WVU OEC was to have fun which is supported in previous literature by Todd, et al. (2002). This was followed by enjoying the company of those who the participant came with and to build relationships. To be challenged and to be 
outdoors came in closely after which was also supported through the literature by Todd, et al.(2002). The lowest motivations were to go somewhere kid friendly, to do something on vacation, avoiding everyday life, recalling past satisfactions and to check it off the bucket list. In the literature, Dann (1977) found avoiding everyday life, anomie, to be a high motivating push factor, which is not supported through this study. With kid friendly being the lowest motivation, it can be assumed that most people do not care if it is kid friendly or not.

According to means, the strongest factors are (1) Adventure and Learning, (2) Nature and Outdoors, (4) teamwork and relationship building, and (6) Socialize. Socialize, although having a limited number of items, has the highest mean followed by Nature and Outdoors then Adventure and Learning. The lowest mean comes from Factor 3 - Family and Relaxation.

The next highest factors, Adventure and Learning, and Nature and Outdoors envelope the ideas of risk taking in specific items like "to explore," "to push yourself," and "to be adventurous." This supports findings of Brown and Fraser (2009) who described risk taking as a central concept of motivation in adventure education activities.

\section{RQ3: How satisfied are the participants with their visit?}

The overall satisfaction rating of participants was 4.92 out of 5 . This came as a good note to summarize everything that was to come. That is, most participants were highly satisfied.

Next, individual satisfaction items made up each factor and the following were some that stood out in the positives and negatives. The highest rated items came from the factor of Staff satisfaction, including" The staff stayed positive" $(M=4.95)$ and "The staff was attentive" $(M=$ 4.94). Lowest satisfaction items came from "There was adequate signage for my arrival" $(M=$ 4.12) and "Billing was easy" $(M=4.06)$, which were still relatively high, but lower than the rest. 
Due to the ease of billing being the lowest mean, this issue was looked into. It turns out that the WVU billing systems was paused throughout the time of the survey, due to this problem many invoices were not received. This caused a vast amount of confusion between both management and the customer that needed to pay by invoice. Most of the programs that paid through the eCommerce online payment portal had little to no problems with payment. This option is generally only available to the canopy tour participants, due to policies regarding taxexempt status and large group billing.

With the second lowest mean being the item concerning signage, there is a simple explanation. When the OEC was built in 2007, it was just a small idea in a very large forest. Growing its roots directly above the forest manager office and Westvaco Natural Resource Center, the university wanted to protect its investment by keeping it private for years. Now, ten years later as the popularity and use grows larger, there are difficulties in keeping it a secret. With all the activities that go on that far outside of Morgantown, concerning the different user groups, it is quite easy for many groups to get lost. Simply said, to gain ease of access to the OEC, signs must be made and inserted at key places.

After looking at the individual items, the factors were then analyzed. The lowest factor mean was that of program logistics $(M=4.48)$, which consisted of the pre and post program logistics such as scheduling and billing. The highest factor mean came from the satisfaction of the staff $(M=4.92)$. This factor dealt with the facilitators at the Outdoor Education Center.

Overall, most participants indicated visiting again or informing others of the OEC. There were also a large number of participants who indicated they would pass on their experience to others seeking advice. With a factor mean for loyalty $(M=4.82)$, this is an important finding as words of mouth is one of the top tools in marketing (Yoon \& Uysal, 2005). This type of 
marketing also brings in a large amount of cash inflow on a per customer basis (Olivia et al., 1992).

When studying loyalty, all factors are considered, however, the only factor that truly matters is the one that produces results. Analyzing the difference between connotative loyalty (intended) and action loyalty (actual) will be an important aspect in the future for this survey (Lee et al., 2007; Oliver, 1999). Currently, there is no definite way in telling if all the customers who said they would be loyal will become loyal, or even tell others of their experience. Due to the timing of the study and the configuration of the seasonality in operations, further research is needed for the above-mentioned action loyalty.

With this in mind, the WVU OEC has many programs that are considered to be potential return groups. As for the return individuals, i.e. canopy tour participants, only time will be able to tell. Since the start of the study, diversification of program styles has begun with the addition of pay to play challenge course options. These include low facilitation and high variation in customizable possibilities throughout the many elements involved in the challenge course.

\section{RQ4: What are the similarities and differences between the four user groups?}

As shown in Tables 16, 17, 18 and 19, there were no significant differences between the male and female respondents or the first time and return visitors, however there are quite a few significant differences in expectations, motivations, satisfaction and loyalty between the group organizers and the participants, as well as the activity that was participated in.

\section{First Time/ Return Visitor}

Looking at the differences between first-time and return visitors, there were no significant differences in any of the constructs examined. This could suggest an easy transition 
between a first and second visit. This also shows that many of the first-time visitors are similar to the return visitors and could in turn become return visitors as well.

As for the lack of differences between first-time visitors and return visitors, there are many studies (Fakeye \& Crompton, 1991; Gitelson \& Crompton, 1984; Hung \& Li, 2016; Lau \& McKercher, 2004; McKercher \& Wong, 2004; Oppermann, 1998; Petrick, 2004; Shanka \& Taylor, 2004) that exemplify the need for understanding the differences between the two, in terms of expectations, motivations, satisfaction and loyalty, however, this study did not find any differences. Although this study did not support these findings, Hughes \& Morrison-Saunders (2002) found no significant differences between first-time and return visitors in a demographic sense when the issue becomes experience specific. In addition, Oppermann (1997) shows that understanding of both these groups is important to success of a recreation experience and should be kept in balance.

Lacking this difference shows conflict with these previous studies. Reasons for this could be the fact that many of the groups are WVU specific groups, with this in mind, it is cheaper for groups to go to the OEC than some outside destination. Also, many of the groups that come to the OEC, only come once a year with their group, maybe twice if they are in multiple groups. The third reason behind this finding was mentioned above with some of the group organizers not participating in the activity. Many, not all of the return participants are the group organizers. Some of these group organizers have been bringing their groups to the OEC since the beginning in 2007 .

\section{Male/Female}

When differentiating gender of an individual participating at the Outdoor Education Center, there again is no significant difference, which conflicts with findings of Sugarman, 
(2001) that looked into retirees. In terms of male and female, Gartner \& Lime (2000) suggest that without gender differences, there is a missing component, however actively attempting to give "equal" opportunities can, in turn, create troubles for select individuals. The idea of equity rather than equality should still envelope the overall program and provide alternative options for those involved (Gartner \& Lime, 2000).

Being that this study did not find significant differences between males and females, some assumptions can be made. First, when the idea of zip lines and challenge courses come into play, males and females have similar thoughts throughout their experience. This assumption is supported by Christensen, Williams and Clark (1987) who showed in outdoor settings, men and women are more similar than different. Second, all participants are treated with equity at the OEC, with an almost even balance of male and female facilitators, groups are usually mixed up evenly as well and given all they need to succeed. Third, during a program at the OEC, participants are encouraged to share and communicate their needs, with this additional prompt, we do find that all individuals can be as open and involved as any other person.

\section{Group Contact/Participant}

As assumed, there were quite a few significant differences between the group contacts and the participants within the groups, which was shown in many factors throughout the t-tests. This could suggest that group contacts should be better informed of what to tell the rest of their group, or they just need to tell them about it. This in turn would allow expectations and motivations to correlate better with the actual experience and therefore, as this study has shown, increase overall satisfaction.

On average the program contact rated all significant factors higher than the participant. When group contacts are involved in programs, usually they watch and do not participate. There 
are, of course, some that do join in the activities along with their peers, but most choose to observe the progress of the group.

The differences that came from group organizer status was empirically witnessed at the OEC and was a main concern of the management team. With many participants unsure of what they were getting themselves into the day of their program, there was an obvious breakdown of communication. Sometimes partcipants came without proper footwear, or outdoor gear in general. To combat this, half-way through the summer, a program packet was made to so the organizers could share information with their group participants. This packet not only included the general expectations from a day at the OEC, but also contained the assumption of risk packet that needed to be filled out before the time of participation. There has not been an abundance of research on this topic, expecially as it concerns outdoor recreation activities.

\section{Canopy Tour/Challenge Course/Both}

The final significant differences from this study came from activity choice for the day at the OEC. Although it would seem like second nature that all activities have different expectations and motivations, for marketing purposes, we wanted to find ways to market all activites together, as well as being able to exemplify each individual activity. As Driver (1977; 1983) showed, there are many motivations when going into outdoor recreation activities. These are derived from various expectations that have been gathered previously. With over 230 different potential motivations, it would be rather difficult to gain insight of every probable answer. In response to this, the qualitative pre-survey suggested by Luo \& Deng (2007), Holden and Sparrowhawk (2002), and Hvengard (2002) did create constraints on the possible responses that could be given to 30 expectations and 38 motivations. With this, there is the chance that some expectations and motivations were not found in the pre-survey. 
Within expectations, there were significant differences in Factor 1- Adventure experience between challenge course and canopy tour $(p=.002)$ and challenge course and both $(p=.065)$. This factor was expected more by the groups that were involved with canopy tour in one way or another. Factor 3 Outdoor learning and punctuality also showed significant differences between canopy tour and challenge course $(p<.001)$ and challenge course and both $(p<.001)$. The mean differences for this factor showed it was expected more by those participating in the canopy tour at some point throughout the day. Cognitive growth and memories showed no significant difference. These results suggest that when it comes to activity choice, there are significant difference in expectations of the adventure experience, and outdoor learning and punctuality between participants of the challenge course and participants of the canopy tour, but the expectations of cognitive growth and memories are shared.

Within motivations, there were no significant differences in Factor 6 - Socialize. This suggests that in all activity choices, socializing is a motivation. Factor 1 - Adventure and learning, also showed no significant differences between groups, suggesting that all programs have the motivations of adventure and learning. All other factors had at least one significant difference between groups. Factor 2 - Nature and outdoors and Factor 3 - Family and relaxation, were significantly higher in programs including the canopy tour in some way. Factor $4-$ Teamwork and relationship building was significantly higher in programs participating in the challenge course somewhere throughout the day. The final significant difference between motivations came from Factor 5 - New experience, which was only significantly higher in programs participating in canopy tour compared to those only on the challenge course.

In satisfactions, there were not many significant differences between activity groups. Comparing the mean differences, canopy tour ended up rating significantly higher than challenge 
course or participants of both activities when there were differences. There were significant differences in facility satisfaction between canopy tour and challenge course $(p=.002)$, suggesting the facilities for the canopy tour were more satisfying than the challenge course. In setting satisfaction, there were significant differences between canopy tour and challenge course $(p=.010)$ and canopy tour and both $(p=.014)$. This could suggest the site of the canopy tour, is also more satisfying than the challenge course. Staff satisfaction saw a significant difference between the canopy tour and challenge course participants $(p=.023)$ and program logistic satisfaction saw a significant difference between canopy tour and challenge course participants $(p<.001)$. These two factors being significantly different only when comparing the individual activities, suggests staffing and logistics were significantly better for the canopy tour than the challenge course. Sign satisfaction, activity satisfaction and loyalty saw no significant differences between groups, suggesting that all programming options felt similar satisfactions about the signage, activity choice and loyalty toward the OEC.

\section{Discussion of SEM Findings and Hypothesis Testing}

Once the 10 hypotheses derived from the research questions were placed into the SEM, the final findings of the study could be analyzed. The first hypothesis, the higher expectations participants have, the more motivated they will be, was found to be to be true with a positive and significant relationship $(p<.001)$. This finding is supported through the literature by Hsu et al. (2010); Lee et al. (2011); and Wong et al. (2013) which have shown motivations are a direct product of valence and expectations.

The second and third hypotheses, participants with a higher level of expectation will be more satisfied with their activities at the OEC and, participants with a higher level of expectation will be more satisfied with OEC staff/facilitators both showed a positive correlation, yet they 
were insignificant. This finding partially supports findings by Langgat et al. (2012), however the findings in said study were significant.

The fourth and fifth hypotheses, participants with a higher level of motivation will be more satisfied with their activities at the OEC and, participants with a higher level of motivation will be more satisfied with OEC staff/facilitators both showed a positive relationship, however, they were insignificant. Seeing how the correlations are positive, this study partially supports findings by Langgat et al. (2012).

Hypothesis six, A higher level of expectation will lead to a higher level of overall satisfaction did not show a significant or positive relationship. This does not support findings in the literature by Mackay and Crompton (1988); Oliver (1980); and Wong et al. (2013) which saw direct relationships between the two. In response to these findings, possible explanations of this may come from the model itself. Due to the fact there were many exogenous and endogenous variables available for the model, the model was complex. Attributable to this complication, the model was simplified to a few select variables. If these items were to be placed back into the model, there is the chance these results would change.

The seventh hypothesis, higher levels of motivation will lead to a higher level of overall satisfaction showed a significant positive correlation. This supports findings by Crompton \& McKay (1997); Dann (1981); Ross and Iso-Ahola (1991), and Wong et al. (2013) which found a similar relationship in multiple aspects of recreation.

Hypotheses eight and nine, satisfaction with activities will significantly contribute to overall satisfaction $(p<.001)$ and satisfaction with staff/facilitators $(p<.01)$ will significantly contribute to overall satisfaction both showed a significant positive correlation. This finding is 
supported in the literature by Langgat et al. (2012) who states that for events, individualized satisfactions like activity and facility will affect the overall satisfaction.

The tenth and final hypothesis, participants who are more satisfied overall will be more loyal to the OEC confirmed a strong significant and positive relationship between the two. This finding is supported by findings in Andreassen and Lindestead (1998); Gronholdt et al. (2000); Lee et al. (2011); Oliver (1999); Yoon and Uysal (2005). These studies recognized the significance between overall satisfaction of a consumer to loyalty and return visitation in various industries.

\section{RQ5: What will bring about the highest return visitation}

The final research question for this study comes as a general summarization. With loyalty producing a significant amount of profitability (Bowen \& Chen, 2001; Hallowell, 1996; Olivia et al., 1992), it is of general interest to any business owner. From the hypothesis testing in the structural equation model, it can be assumed that satisfaction with activity and staff will be the biggest determinants to overall satisfaction and, in turn, future visitation at the Outdoor Education Center. Although the other factors in satisfaction of the experience will be contributors of the loyalty factor, the satisfaction with the activity and staff will be the largest contributors. 


\section{CHAPTER 6: CONCLUSIONS}

While expectations, motivations, satisfaction and loyalty have been widely examined in the literature, few studies, if any, have been conducted to examine perceptional similarities and differences between participants and interrelationships between these variables in the context of outdoor adventure recreation. This study filled this gap by looking at similarities and differences between gender, return visitation, organizer status, different activities participated in. It then examined the relationships between the four constructs of expectation, motivation, satisfaction and loyalty at the WVU Outdoor Education Center, one of the largest such centers in the United States. Interestingly, this study found that no significant differences exist between male and female visitors as well as return visitors and first time visitors. However, the study did find significant differences between organizer status and activity participated in. The study also found expectations significantly and positively contribute to motivations, motivations significantly and positively contribute to overall satisfaction, which also significantly and positively contributes to loyalty. This study also found a positive, yet insignificant, contribution from motivations and expectations toward factor satisfaction, and a significant positive contribution from factor satisfaction toward overall satisfaction. This study found no significant or positive influence from expectations to overall satisfactions, which contradicts much of the reviewed literature This study is of significant theoretical, methodological, and managerial implications.

\section{Research Findings}

Looking at the hypotheses from this study, we can confirm eight findings.

1. Using a qualitative survey to find motivations allowed for more precise answers.

2. There is a significant positive relationship between expectations and motivations. 
3. There is a positive yet insignificant correlation between expectations and factor satisfaction.

4. The is a positive yet insignificant correlation between motivations and factor satisfaction.

5. There is not a significant or positive correlation between expectations and overall satisfaction.

6. There is a positive significant correlation between motivations and overall satisfaction.

7. There is a significant positive relationship between factor satisfaction and overall satisfaction.

8. There is a significant positive relationship between overall satisfaction and loyalty.

\section{Theoretical Implications}

As previous studies (Holden \& Sparrowhawk, 2002; Hvengard, 2002; Luo \& Deng, 2007) suggest, a qualitative pre-survey was used to derive statements that measure expectations and motivations. This strategy was used in combination with the REP scale (Driver, 1977; 1983) to better understand why people are going to the OEC. This method provided emphasis for four factors of expectations and six factors to make up motivations of going to organizations like the OEC. These organizations should contain zip lines and challenge courses based around a university setting.

For these organizations, the expectations and motivations can be measured by six satisfaction characteristics and one loyalty. Itemizing these seven factors can bring about higher understanding of why customers are satisfied or dissatisfied, however, longer online surveys will more than likely bring about skewed results and not have ideal participation that complete it to the entirety (Peytchev, 2009).

Based upon this study, the following theoretical implications have been gathered: 
1. Expectations significantly predict motivations when visiting a tourist destination, This finding supports literature from Hsu et al. (2010) and Lee et al. (2011).

2. Pre-exposure variables such as expectation, do not signify levels of overall satisfaction. This finding contradicts literature by Oliver (1980) and Wong et al. (2013).

3. There is a significant positive correlation from motivation to overall satisfaction, which supports studies by Crompton \& Mckay(1997); Dann (1981); Ross and Iso-Ahola (1991) and Wong et al. (2013).

4. Itemized expectations and motivations can indicate their corresponding satisfactions, which partially supports literature by Langgat et al. (2012). In this study, no significant correlation was found between expectations and itemized satisfaction, however the relationship was positive.

5. Itemized Satisfaction can significantly indicate overall satisfaction which is supported by findings of Langgat et al., (2012).

6. Satisfaction significantly indicates loyalty which supports studies by Andreassen \& Lindestead (1998); Gronholdt et al. (2000); Lee et al. (2011); Oliver (1999), and Yoon and Uysal (2005).

\section{Management Implications}

From the theoretical implications, practical management implications have also been prescribed from this study.

First of all, specific to the OEC, better billing system should be explored. Due to the fact, it is a West Virginia state-run institution, the OEC should abide by specific policies when invoicing. The OEC has taken great strides to improve these issues, but currently lacks the ability to upgrade systems as a whole. 
Again, specific to the OEC, signage needs to be developed to bring consumers directly to the site. As of now, there is minimal signage due to the original design perspectives of the OEC. Lack of signage was used as a way to keep people out when no one is on-site. With the necessity moving from keeping people out, to bringing people in, this research has shown data supporting these needs.

Third, all service companies similar to the OEC should look into what motivates their customers and what they expect. Without this basic understanding, there could be a misconception of why customers are coming.

Fourth, if the survey participants have not been briefed of the overall experience, there is the high possibility that their satisfaction will be low. Orientations to the activity are suggested. Surprise parties may not be the best time to ask for a survey, however, if the participant has low expectations of their day, their satisfaction could be quite high. Keep these two aspects in mind when scheduling programs.

Fifth, make sure the program is challenging and worth the cost, but also make sure your participants are prepared and taken care of during that time. They came there to push themselves and be adventurous in a safe environment; to learn and experience something new. And they expect friendly service, an adrenaline rush, experiencing physical growth, having fun, recreating, and being excited.

Sixth, once these satisfaction levels are high, keep them high. Although your participants have left, marketing materials and future discounts could bring them back later. Another way to do this is by having tangible materials available directly after the conclusion of the experience. This could be items such as, trail maps, discount books for the local area, convention and visitor bureau pamphlets, or other area attraction ideas. 
Seventh and finally, although the OEC was designed to be an educational outdoor learning center, the expectations and motivations of the participants do not align with the overall brand. This study has shown data revealing education is of the lowest expectations and motivations. On the other hand, the highest expectations and motivations revolve around the adventure aspects of the OEC. These findings suggest less emphasis in marketing toward the educational aspect, and more emphasis on the adventure and outdoor aspects of the OEC.

\section{Limitations}

After every program at the OEC a feedback form goes out to the program contact, which allows the participant to give general feedback about their experience. Due to this, the survey involved in this study had to be sent out a week after the feedback form was sent. This could have caused the low amount of participation in this survey. It could have also distorted the views of participants being that it was not a direct ex post facto survey.

During the time of the survey, there were many new facilities being added and upgraded. This caused large construction vehicles to move dirt and create an incomplete setting during the 2016 summer. It also took some of the nature feeling from the site as a whole.

With these site changes, many of the activities became limited to lower numbers than previously. Therefore, the overall participant count during the surveying period was lower than the numbers of the previous season. The low participant numbers caused a shift in the original survey method of random sampling to convenience sampling.

Not only were updates being done to the facility, but many of the logistical procedures were also being changed. Half way through the survey period, a program packet was developed to assist participant understanding of their selected program. This could have changed overall logistical satisfaction. 


\section{Implications for future research}

Being that there has not been much research done for this topic in particular, there is need for further research. Studies like this should be done at similar businesses to compare results across multiple sites.

In the future, we would like to find out if the participants who indicated connotative loyalty toward the OEC will return and/or tell their friends and family.

For this survey to have increased value, a larger sample size is wanted. We will be looking at ways to increase survey numbers to increase reliability of the data.

The strategy used for this study's pre-survey came from the notion from Luo \& Deng (2007), which showed reason strategies in deriving simplified measures of motivations and expectations. This made the current version of the survey much smaller than the original.

Other research ideas that can be implemented into this type of study could focus on dissatisfaction and how the variables in this study can relate to that. If one of these constructs are not fulfilled, how does that impact overall satisfaction and thereon, loyalty.

The last implication for further research involves the idea of risk management towards satisfaction. In the outdoor adventure industry, there is a large focus on risk management, however, there is not a consensus of large types of risk management. Not only is there no consensus, but in dealing with different types of risk, there could be a potential to dissatisfy a participant. This future study should look at the types of risk management and how properly managing these variables can affect the overall satisfaction and loyalty of the participants. 


\section{BIBLIOGRAPHY}

Adventure West Virginia. (2016, Novemer 30). Adventure WV. Retrieved from Adventure WV Home: https://adventurewv.wvu.edu/

Anderson, J. C., \& Gerbing, D. W. (1988). Structural equation modeling in practice: A review and recommended two-step approach. Psychological Bulletin, 103(3), 411-423.

Andreassen, T., \& Lindestead, B. (1998). The Effect of Corporate Image in the formation of customer loyalty. Journal of Service Research, 1(1), 82-92.

Baker, D., \& Crompton, J. (2000). Quality, Satisfaction and Behavioural Intentions. Annals of Tourism Reearch, 27(3), 785-804.

Boulding, W., Lakra, A., Staelin, R., \& Zeithaml, V. (1993, February). A Dynamic Process model of service Quality. Journal of Marketing Research, 30, 7-27.

Bowen, J. T., \& Chen, S. (2001). The relationship between customer loyalty and customer satisfaction. International Journal of Contemporary Hospitality Management, 13(5), 213217.

Brown, M., \& Fraser, D. (2009). Re-evaluating risk and exploring educational alternatives. Journal of Adventure Education and Outdoor Learning, 9, 61-77.

Cadotte, E., Woodruff, R., \& Jenkins, R. (1987). Expectations and Norms in Models of Consumer Satisfaction. Journal of Maketing Research, 24(3), 305-314.

Chen, C., \& Tsai, D. (2007). How destination image and evaluative factors affect behavioral intentions? Tourism Management, 28(1), 1115-1122.

Chi, C. G., \& Qu, H. (2008). Examining the structural relationships of destination image, tourist satisfaction and destination loyalty: An integrated approach. . Tourism Management, 29, 624-636. 
Christensen, H., Williams, P., \& Clark, R. (1987). Values and Choices in Outdoor Recreation by Male and Female Campers in Dispersed Recreation Areas. Research Paper, United States Department of Agriculture, Forest Service, Pacific Northwest Research Station, Portland, OR.

Clark, K. (1989). Beyond Service Fads - Meaningful Strategies for the Real World. Sloan Management Review, 30(2), 69-76.

Clark, R., \& Stankey, G. (1979). The Recreation Opportunity Spectrum: A Framework for Planning, Management and Research Symposium. USDA Forest Service.

Coyne, K. (1989). Beyond service fads - meaningful strategies for thereal world. Sloan Management Review, 30(2), 69-76.

Crandall, R. (1980). Motivations for Leisure. Journal of Leisure Research, 12, 45-54.

Crompton, J., \& Mckay, S. (1997). Motive of Visitors Attending Fesitval Events. Annals of Tourism Research, 24(2), 425-439.

Crompton, J., MacKay, K., \& Fesenmaier, D. (1991). Identifying Dimensions of Service Quality in Public Recreation. Journal of Park and Recreation Administration, 9(3), 15-28.

Dann, G. (1977). Anomie, Ego-Enhancement and Tourism. Annals of Tourism Research, 4, 184194.

Dann, G. (1981). Tourism Motivation: An Appraisal. Annals of Tourism Research, 8, 187-219.

De Ruyter, J. K., Wetzels, M., Lemmink, J., \& Mattson, J. (1997). The Dynamics of the Service Delivery Process: A Value-Base Aprroach. International Journal of Research in Marketing, 14, 231-243.

Deng, J., Kathryn, A., Pierskalla, C., \& McNeel, J. (2010). Linking urban forests and urban tourism: A case of Savannah, GA. Tourism Analysis, 15(2), 167-181. 
Dillman, D. (2000). Mail and internet surveys : the tailored design method (2nd ed.). New York.

Driver, B. (1977). Item Pool for Scales Designed to Quantify thePsychological Outcomes Desired and Expected from Recreational Participatin. Fort Collins, CO: USDA Forest Service.

Driver, B. (1983). Master List of Items for Recreation Experience Preference Scales and Domains. Fort Collins, CO: USDA Forest Service.

Ellis, G., \& Rossman, J. (2008). Creating Value for Participants through Experience Staging: Parks, Recreation, and Tourism in the Experience Industry. . Journal of Park and Recreation Administration, 26(4), 1-20.

Ewert, A. (1989). Models and Theories in Outdoor Adventure Pursuits. In Outdoor Adventure Pursuits: Foundations, Models, and Theories (pp. 83-102). Columbus, Ohio: Horizons.

Ewert, A., \& Hollenhorst, S. (1989). Testing the Adventure Recreation Model: Empirical Support for a Model of Risk Recreation Participation. Journal of Leisure Research, 21, 124-139.

Ewert, A., \& Hollenhorst, S. (1997). Adventure recreation and its implications for wilderness. International Journal of Wildrness, 3(2), 21-26.

Fakeye, P. C., \& Crompton, J. L. (1991). Image differences between prospective, firsttime, and repeat visitors to the lower Rio Grande Valley. Journal of Travel Research, 30(2), 10-16.

Fletcher, D., \& Fletcher, H. (2003). Manageable Predictors of Park Visitor Satisfaction: Maintenance and Personnel. Journal of Park and Recreation Administration, 21(1), 2137. 
Frennea, C., Mittal, V., \& Westbrook, R. (2014). The Satisfaction Profit Chain. In E. Elgar, R. Rust, \& M. Huang (Eds.), Handbook of service marketing research (pp. 182-218). Northampton, Massachusetts: Edward Elgar Publishing, Inc.

Gartner, W., \& Lime, D. (Eds.). (2000). Trends in Outdoor Recreation, Leisure, and Tourism. Cabi Publishing.

Gitelson, R. J., \& Crompton, J. L. (1984). Insights into the repeat vacation phenomenon. Annals of Tourism Research, 11(2), 199-217.

Gnoth, J. (1997). Tourism motivation and expectation formation. Annals of Tourism Research, $24(2), 283-304$.

Gronholdt, L., Martensen, A., \& Kristensen, K. (2000). The relationship between customer satisfaction and loyalty: Cross-industry differences. Total Quality Management, 11(4-6), $509-514$.

Hallowell, R. (1996). The relationships of customer satisfaction, customer loyalty, and profitability: An empirical study. International Journal of Service Industry Management International Journal of Service Industry Management, 7(4), 27-42.

Hoden, M. (2010). Constraints to Participation in an Outdoor Orientation Program. Master Thesis, West Virginia University, Electronic Thesis and Dissertations, Morgantown, WV.

Holden, A., \& Sparrowhawk, J. (2002). Understanding the Motivations of Ecotourists; The Case of Trekkers in Annapurna, Nepal. Internation Journal of Tourism Research, 4, 435-446.

Hooper, D., Coughlan, J., \& Mullen, M. R. (2008). Structural equation modeling: Guidelines for determining model fit. Electronic Journal of Business Research Methods, 6(1), 53-60.

Hsu, C. H., Cai, L. A., \& Li, M. (2010, Aug). Expectation, Motivation, and Attitude: A Tourist Behavioral Model. Journal of Travel Research, 49(3), 282-296. 
Huang, S., \& Hsu, C. H. (2009). Effects of travel motivation, past experience, perceived constraint, and attitude on revisit intention. Journal of Travel Research, 48(1), 29-44.

Hughes, M., \& Morrison-Saunders, A. (2002). Repeat and First Time Visitation in an Experience Specific Context: The Valley of the Giants Tree Top Walk. The Journal of Tourism Studies, 13(1), 20-25.

Hung, K., \& Li, X. (2016). Chinese Consumers in a New Era: Their Travel Behaviors and Psychology. Routledge.

Hvengard, G. T. (2002). Using Tourist Typologies for Ecotourism Research. Journal of Ecotourism, 1(1), 7-18.

Iso-Ahola, S. E. (1980). The Social Psychology of Leisure and Recreation. Dubuque, Iowa: Wm. C. Brown.

Kim, K., Oh, I., \& Jogaratnam, G. (2007). College student travel: A revised model of push motives. Journal of Vacation Marketing, 13(1), 73-85.

Klenosky, D. B. (2002, May 1). The "Pull” of Tourism Destinations: A Means-End Investigation. Journal of Travel Research, 40(4), 396-403.

Langgat, J., Marzuki, K. M., Fabeil, N. F., \& Dahnil, I. (2012, December). Visitor Motivation, Expectation and Satisfaction of Local Cultural Event in Sabah, A Case Study Of Tamu Besar Kota Belud. International Journal of Culture and Tourism Research, 5(1), 48-59.

Lau, A. L., \& McKercher, B. (2004). Exploration versus acquisition: A comparison of first-time and repeat visitors. Journal of Travel Research, 42(3), 279-285.

Lee, J., Grafe, A. R., \& Burns, R. C. (2007). Examining the Antecedents of Destination Loyalty in a Forest Setting. Leisure Sciences, 29(5), 463-481. 
Lee, S., Jeon, S., \& Kim, D. (2011). The impact of tour quality and tourist satisfaction on tourist loyalty: The case of Chinese tourists in Korea. Tourism Management, 32, 1115-1124.

Lewis, C., \& Booms, B. (1983). The marketing aspects of service quality. Emerging Perspectives on Services Marketing, 99-107.

Luo, Y., \& Deng, J. (2007). The New Environmental Paradigm and Nature-Based Tourism Motivation. Journal of Travel Research, 46(4), 392-402.

MacCallum, R. C., Browne, M. W., \& Sugawara, H. M. (1996). Power analysis and determination of sample size for covariance structure modeling. Psychological Methods, $1(2), 130-149$.

Mackay, K., \& Crompton, J. (1988). A conceptual model of consumer evaluation of recreation service quality. Leisure Studies, 7, 41-49.

Manfredo, M. J., Driver, B. L., \& Tarrant, M. A. (1996). Measuring leisure motivation: A metaanalysis of the recreation experience preference scales. Journal of Leisure Research, 28, $188-213$.

Manning, R. (1986). Studies in outdoor recreation: Search and research for satisfaction. Corvallis: Oregon State Univrsity Press.

Manning, R. (1999). Studies in outdoor recreation: Search and research for satisfaction. Corvallis: Oregon State University Press.

Manning, R. (2011). Studies in outdoor recreation: Search and research for satisfaction. Corvallis: Oregon State Univeristy Press.

McKercher, B., \& Wong, D. Y. (2004). Understanding tourism behavior: Examining the combined effects of prior visitation history and destination status. Journal of Travel Research, 43(2), 171-179. 
Oliver, R. L. (1980). A Cognitive Model of the Antecedents and Consequences of Satisfaction Decisions. Journal of Marketing Research, 17(4), 460-469.

Oliver, R. L. (1997). Satisfaction: A behavioral perspective on the consumer. Boston, MA: McGraw-Hill.

Oliver, R. L. (1999). Whence consumer loyalty? . Journal of Marketing, 63(Special), 33-44.

Olivia, T. A., Oliver, R. L., \& Macmillan, I. C. (1992, July). A Catastrophe Model for Developing Service Satisfaction Strategies. Journal of Marketing, 56(3), 83-95.

Oppermann, M. (1997). First-time and repeat tourists to New Zealand. Tourism Management, 18(3), 177-181.

Oppermann, M. (1998). Destination threshold potential and the law of repeat visitation. Tourism Management, 37(2), 131-137.

Ostrowski, P., O'Brien, T., \& Gordon, G. (1993). Service quality and customer loyalty in the commercial airline industry. Journal of Travel Research, 32(3), 16-24.

Parasuraman, A., Zeithaml, V., \& Berry, L. (1985). A Conceptual Model of Service Quality and Its Implications for Future Research. Journal of Marketing, 49, 41-50.

Petrick, J. F. (2004). First timers' and repeaters' perceived value. Journal of Travel Research, 43(1), 29-38.

Peytchev, A. (2009). Survey Breakoff. Public Opinion Quarterly, 73(1), 74-97.

Rose, G. (1966). Anomie and Deviation - A Conceptual Framework for Empirical Studies. British Journal of Sociology, 17, 29-34.

Ross, E., \& Iso-Ahola, S. (1991). Sightseeing Tourists' Motivation and Satisfaction. Annals of Tourism Research, 18, 226-237. 
Shanka, T., \& Taylor, R. (2004). Discriminating factors of first-time and repeat visitors to wine festivals. Current Issues in Tourism, 7(2), 134-145.

Sugarman, D. (2001). Motivations of Older Adults to Participate in Oudoor Adventure experiences. Journal of Adventure Education and Outdoor Learning, 1(2), 21-34.

Todd, S. L., Anderson, L., Young, A., \& Anderson, D. (2002). The relationship of motivation factors to level of development in outdoor adventure recreationists. Research in Outdoor Education, 6, 124-138.

Tse, D. K., \& Wilton, P. C. (1988, May). Models of Consumer Satisfaction Formation: An Extension. Journal of Marketing Research, 25(2), 204-212.

Tsuar, S., Lin, R., \& Cheng, T. (2015). Toward a Structural Model of Challenge Experience in Adventure Recreation. Journal of Leisure Research, 47(3), 322-336.

Vroom, V. H. (1964). Work and motivation. New York: Wiley.

Wheaton, B., Muthen, B., Alwin, D. F., \& Summer, G. F. (1977). Assessing Reliability and Stability in Panel Models. Sociological Methodology , 8, 84-136.

Williams, P., \& Soutar, G. (2009). Value, Satisfaction And Behavioral Intentions In An Adventure Tourism Context. Annals of Tourism Research, 36(3), 413-438.

Wong, M., Cheung, R., \& Wan, C. (2013, June). A Study on Traveler Expectation, Motivation and Attitude. Contemporary Management Research, 9(2), 169-186.

Yoon, Y., \& Uysal, M. (2005). An examination of the effects of motivation and satisfaction on destination loyalty: a structural model. Tourism Management, 26, 45-56.

Ziethaml, V. A., Berry, L. L., \& Parasuraman, A. (1996). The behavioral consequences of service quality. Journal of Marketing, 60(2), 31-46. 


\section{APPENDIX}

\section{Appendix A: Survey Instrument}

\section{W-WestVirginiaUniversity.}

\section{Part A}

The purpose of this survey is to understand user satisfaction and return visitation of participants at the West Virginia University Outdoor Education Center (WVU OEC). The results of this survey will help to identify the degree to which management tactics at the WVU OEC match the motivations and expectations of the average user to better serve its customers.

Please answer the following questions to the best of your ability by circling the appropriate answer or writing your response in the space provided. All information provided will be kept confidential. If you feel unsure or uncomfortable answering any question, please leave it blank. This research survey has been acknowledged for use by West Virginia University's IRB (Institutional Review Board). It will take you about 10 minutes to complete the questionnaire.

Once finished, your name can be inserted into a drawing for 2 canopy tour spots at the Newly updated WVU Canopy Zip Line Tour or a \$25 gift certificate to Hugh Baby's

Thank you!

\section{Section I: Awareness of and Knowledge about the OEC}

Part A:

Before scheduling your program, have you been to the WVU OEC?

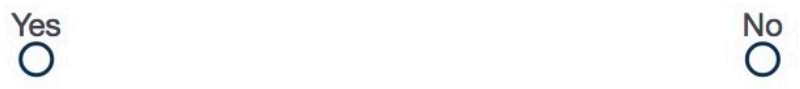

Please select all WVU OEC activities you have participated in within the past 12 months. 
Read newsletters

Read Emails

Seen Press Story, display, or presentation

$\square$ Seen Ads on Social Media

Participated in a Portable Initiatives Program

Participated in the Zip Line Canopy Tour $\square$ Participated in a Low Ropes Program

$\square$ Participated in a High Ropes Program

$\square$ Attended a tour or special event

$\square$ Been on an Adventure WV Orientation Trip

$\square$ Other

If you chose Other, please specify

\section{Part B}

\section{Part B:}

Listed below are statements concerning what you know about the WVU OEC. Please indicate if you agree or disagree with each statement by choosing your response based on the following scale.

Programming at the WVU OEC is about challenging yourself WVU OEC is a nonprofit organization

The WVU OEC promotes community engagement

WVU OEC is managed by Adventure WV

The WVU OEC envelopes a sense of Quality and Professionalism

$\begin{array}{ccccc}\begin{array}{c}\text { Strongly } \\ \text { disagree }\end{array} & \begin{array}{c}\text { Somewhat } \\ \text { disagree }\end{array} & \begin{array}{c}\text { Neither agree } \\ \text { nor disagree }\end{array} & \begin{array}{c}\text { Somewhat } \\ \text { agree }\end{array} & \begin{array}{c}\text { Strongly } \\ \text { agree }\end{array} \\ 0 & 0 & 0 & 0 & 0 \\ 0 & 0 & 0 & 0 & 0 \\ 0 & 0 & 0 & 0 & 0 \\ \begin{array}{c}\text { Strongly } \\ \text { disagree }\end{array} & \begin{array}{c}\text { Somewhat } \\ \text { disagree }\end{array} & \begin{array}{c}\text { Neither agree } \\ \text { nor disagree }\end{array} & \begin{array}{c}\text { Somewhat } \\ \text { agree }\end{array} & \begin{array}{c}\text { Strongly } \\ \text { agree }\end{array}\end{array}$




\begin{tabular}{|c|c|c|c|c|c|}
\hline & $\begin{array}{l}\text { Strongly } \\
\text { disagree }\end{array}$ & $\begin{array}{l}\text { Somewhat } \\
\text { disagree }\end{array}$ & $\begin{array}{c}\text { Neither agree } \\
\text { nor disagree }\end{array}$ & $\begin{array}{l}\text { Somewhat } \\
\text { agree }\end{array}$ & $\begin{array}{c}\text { Strongly } \\
\text { agree }\end{array}$ \\
\hline $\begin{array}{l}\text { WVU OEC is one of } \\
\text { largest Outdoor } \\
\text { Education Centers on } \\
\text { the East Coast }\end{array}$ & 0 & $\bigcirc$ & $\bigcirc$ & $\bigcirc$ & $\bigcirc$ \\
\hline $\begin{array}{l}\text { WVU OEC is used to } \\
\text { learn about the } \\
\text { outdoors }\end{array}$ & 0 & $\bigcirc$ & $\bigcirc$ & 0 & $\bigcirc$ \\
\hline \multirow[t]{2}{*}{$\begin{array}{l}\text { WVU OEC is essentially } \\
\text { a recreational resort }\end{array}$} & 0 & $\bigcirc$ & $\bigcirc$ & $\bigcirc$ & 0 \\
\hline & $\begin{array}{l}\text { Strongly } \\
\text { disagree }\end{array}$ & $\begin{array}{l}\text { Somewhat } \\
\text { disagree }\end{array}$ & $\begin{array}{c}\text { Neither agree } \\
\text { nor disagree }\end{array}$ & $\begin{array}{l}\text { Somewhat } \\
\text { agree }\end{array}$ & $\begin{array}{c}\text { Strongly } \\
\text { agree }\end{array}$ \\
\hline $\begin{array}{l}\text { The WVU OEC is all } \\
\text { about thrilling and } \\
\text { challenging recreational } \\
\text { opportunities }\end{array}$ & $\bigcirc$ & $\bigcirc$ & $\bigcirc$ & $\bigcirc$ & $\bigcirc$ \\
\hline $\begin{array}{l}\text { The OEC is affiliated } \\
\text { with WVU }\end{array}$ & $\bigcirc$ & 0 & 0 & 0 & 0 \\
\hline $\begin{array}{l}\text { One purpose of the } \\
\text { WVU OEC is for } \\
\text { student retention }\end{array}$ & 0 & 0 & 0 & 0 & 0 \\
\hline
\end{tabular}

\section{Section 2}

\section{Section II: Motivations of Today's WVU OEC Experience}

Listed below are motivations of adventure recreation programming. Please indicate how much these categories motivated you to participate today by choosing your response.

\begin{tabular}{|c|c|c|c|c|c|}
\hline & Not at all & A little & $\begin{array}{l}\text { A moderate } \\
\text { amount }\end{array}$ & A lot & A great deal \\
\hline To be Challenged & 0 & 0 & $\mathrm{O}$ & 0 & $\mathrm{O}$ \\
\hline To be Adventurous & $\mathrm{O}$ & $\mathrm{O}$ & $\mathrm{O}$ & $\mathrm{O}$ & $\mathrm{O}$ \\
\hline $\begin{array}{l}\text { To go somewhere Kid } \\
\text { friendly }\end{array}$ & $\mathrm{O}$ & $\mathrm{O}$ & $\mathrm{O}$ & $\mathrm{O}$ & $\mathrm{O}$ \\
\hline To Learn & $\mathrm{O}$ & $\mathrm{O}$ & $\mathrm{O}$ & O & O \\
\hline $\begin{array}{l}\text { To enjoy the smells and } \\
\text { sounds of nature }\end{array}$ & $\mathrm{O}$ & $\mathrm{O}$ & $\mathrm{O}$ & 0 & 0 \\
\hline $\begin{array}{l}\text { To experience } \\
\text { Something new }\end{array}$ & $\mathrm{O}$ & $\mathrm{O}$ & $\mathrm{O}$ & $\mathrm{O}$ & 0 \\
\hline
\end{tabular}




\begin{tabular}{|c|c|c|c|c|c|}
\hline & Not at all & A little & $\begin{array}{l}\text { A moderate } \\
\text { amount }\end{array}$ & A lot & A great deal \\
\hline $\begin{array}{l}\text { To lead team } \\
\text { development }\end{array}$ & $\mathrm{O}$ & $\mathrm{O}$ & $\mathrm{O}$ & $\mathrm{O}$ & O \\
\hline \multirow[t]{2}{*}{ To be Entertained } & O & O & $\mathrm{O}$ & O & O \\
\hline & Not at all & A little & $\begin{array}{l}\text { A moderate } \\
\text { amount }\end{array}$ & A lot & A great deal \\
\hline To enjoy Scenic View & 0 & 0 & 0 & $\mathrm{O}$ & 0 \\
\hline To Avoid Every Day Life & O & $\mathrm{O}$ & $\mathrm{O}$ & $\mathrm{O}$ & $\mathrm{O}$ \\
\hline To Build Relationships & O & O & O & O & O \\
\hline $\begin{array}{l}\text { To support Local } \\
\text { Business }\end{array}$ & $\mathrm{O}$ & $\mathrm{O}$ & $\mathrm{O}$ & $\mathrm{O}$ & O \\
\hline $\begin{array}{l}\text { To enhance Self- } \\
\text { esteem }\end{array}$ & O & $\mathrm{O}$ & O & O & $\bigcirc$ \\
\hline $\begin{array}{l}\text { To enjoy the company } \\
\text { of people who came } \\
\text { with me }\end{array}$ & O & O & 0 & $\mathrm{O}$ & O \\
\hline $\begin{array}{l}\text { To recall past } \\
\text { satisfactions }\end{array}$ & 0 & 0 & $\mathrm{O}$ & $\mathrm{O}$ & O \\
\hline \multirow[t]{2}{*}{$\begin{array}{l}\text { To experience Self- } \\
\text { Discovery }\end{array}$} & O & O & O & O & 0 \\
\hline & Not at all & A little & $\begin{array}{l}\text { A moderate } \\
\text { amount }\end{array}$ & A lot & A great deal \\
\hline To be Outdoors & $\mathrm{O}$ & $\mathrm{O}$ & $\mathrm{O}$ & $\mathrm{O}$ & $\mathrm{O}$ \\
\hline To be Thrilled & $\mathrm{O}$ & $\mathrm{O}$ & $\mathrm{O}$ & $\mathrm{O}$ & $\mathrm{O}$ \\
\hline To go sightseeing & $\mathrm{O}$ & $\mathrm{O}$ & O & $\mathrm{O}$ & $\bigcirc$ \\
\hline $\begin{array}{l}\text { To support WVU } \\
\text { Activity }\end{array}$ & 0 & 0 & 0 & 0 & 0 \\
\hline To be close to Nature & $\mathrm{O}$ & $\mathrm{O}$ & $\mathrm{O}$ & $\mathrm{O}$ & O \\
\hline To Explore & $\mathrm{O}$ & $\mathrm{O}$ & $\mathrm{O}$ & $\mathrm{O}$ & O \\
\hline To enjoy Nice weather & O & O & $\mathrm{O}$ & O & O \\
\hline \multirow[t]{2}{*}{ To be Educated } & O & O & $\mathrm{O}$ & O & O \\
\hline & Not at all & A little & $\begin{array}{l}\text { A moderate } \\
\text { amount }\end{array}$ & A lot & A great deal \\
\hline $\begin{array}{l}\text { Something to do on } \\
\text { Vacation }\end{array}$ & $\mathrm{O}$ & $\mathrm{O}$ & $\mathrm{O}$ & $\mathrm{O}$ & O \\
\hline To Be Social & $\mathrm{O}$ & O & $\mathrm{O}$ & $\mathrm{O}$ & $\mathrm{O}$ \\
\hline To develop Teamwork & $\mathrm{O}$ & $\mathrm{O}$ & $\mathrm{O}$ & $\mathrm{O}$ & $\bigcirc$ \\
\hline $\begin{array}{l}\text { To do an Affordable } \\
\text { actiivty }\end{array}$ & $\mathrm{O}$ & $\mathrm{O}$ & $\mathrm{O}$ & 0 & $\mathrm{O}$ \\
\hline To Push Yourself & $\mathrm{O}$ & $\mathrm{O}$ & $\mathrm{O}$ & $\mathrm{O}$ & $\mathrm{O}$ \\
\hline
\end{tabular}




\begin{tabular}{|c|c|c|c|c|c|}
\hline & Not at all & A little & $\begin{array}{l}\text { A moderate } \\
\text { amount }\end{array}$ & A lot & A great deal \\
\hline $\begin{array}{l}\text { To be out of my comfort } \\
\text { zone }\end{array}$ & $\mathrm{O}$ & $\mathrm{O}$ & $\mathrm{O}$ & $\mathrm{O}$ & 0 \\
\hline Close to Home & $\mathrm{O}$ & $\mathrm{O}$ & $\mathrm{O}$ & $\mathrm{O}$ & $\mathrm{O}$ \\
\hline \multirow[t]{2}{*}{ To Recreate } & $\mathrm{O}$ & $\mathrm{O}$ & $\mathrm{O}$ & O & 0 \\
\hline & Not at all & A little & $\begin{array}{l}\text { A moderate } \\
\text { amount }\end{array}$ & A lot & A great deal \\
\hline $\begin{array}{l}\text { To check it off my } \\
\text { bucketlist }\end{array}$ & $\mathrm{O}$ & $\mathrm{O}$ & $\mathrm{O}$ & $\mathrm{O}$ & $\mathrm{O}$ \\
\hline $\begin{array}{l}\text { To do something in my } \\
\text { free time }\end{array}$ & $\mathrm{O}$ & $\mathrm{O}$ & $\mathrm{O}$ & $\mathrm{O}$ & $\mathrm{O}$ \\
\hline To be Safe & $\mathrm{O}$ & $\mathrm{O}$ & $\mathrm{O}$ & $\mathrm{O}$ & 0 \\
\hline To be with Family & $\mathrm{O}$ & $\mathrm{O}$ & $\mathrm{O}$ & $\mathrm{O}$ & 0 \\
\hline To have Fun & $\mathrm{O}$ & $\mathrm{O}$ & $\mathrm{O}$ & $\mathrm{O}$ & $\mathrm{O}$ \\
\hline To Face Fear & $\mathrm{O}$ & $\mathrm{O}$ & O & $\mathrm{O}$ & 0 \\
\hline
\end{tabular}

\section{Section 3}

\section{Section III: Expectation of Today's WVU OEC Experience}

For today's trip to the WVU OEC, I expected

(Please indicate the extent to which you agree or disagree with each statement)

\begin{tabular}{|c|c|c|c|c|c|}
\hline & $\begin{array}{l}\text { Strongly } \\
\text { disagree }\end{array}$ & $\begin{array}{l}\text { Somewhat } \\
\text { disagree }\end{array}$ & $\begin{array}{l}\text { Neither agree } \\
\text { nor disagree }\end{array}$ & $\begin{array}{l}\text { Somewhat } \\
\text { agree }\end{array}$ & $\begin{array}{l}\text { Strongly } \\
\text { agree }\end{array}$ \\
\hline Meeting new people & $\mathrm{O}$ & 0 & $\mathrm{O}$ & 0 & 0 \\
\hline Experiencing Change & $\mathrm{O}$ & $\mathrm{O}$ & $\mathrm{O}$ & $\mathrm{O}$ & $\mathrm{O}$ \\
\hline $\begin{array}{l}\text { Experiencing Exciting } \\
\text { activities }\end{array}$ & $\mathrm{O}$ & $\mathrm{O}$ & $\mathrm{O}$ & $\mathrm{O}$ & 0 \\
\hline Having a nice event & $\mathrm{O}$ & $\mathrm{O}$ & $\mathrm{O}$ & $\mathrm{O}$ & 0 \\
\hline Having an Adventure & $\mathrm{O}$ & $\bigcirc$ & $\bigcirc$ & $\bigcirc$ & $\mathrm{O}$ \\
\hline $\begin{array}{l}\text { Experiencing An } \\
\text { Adrenaline rush }\end{array}$ & $\mathrm{O}$ & 0 & 0 & $\mathrm{O}$ & $\mathrm{O}$ \\
\hline $\begin{array}{l}\text { Learning about the Zip } \\
\text { Line }\end{array}$ & $\mathrm{O}$ & $\mathrm{O}$ & $\mathrm{O}$ & $\mathrm{O}$ & $\mathrm{O}$ \\
\hline $\begin{array}{l}\text { Learning about the } \\
\text { forest }\end{array}$ & 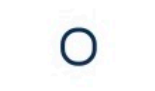 & $\bigcirc$ & $\bigcirc$ & $\mathrm{O}$ & $\mathrm{O}$ \\
\hline
\end{tabular}




\begin{tabular}{|c|c|c|c|c|c|}
\hline & $\begin{array}{l}\text { Strongly } \\
\text { disagree }\end{array}$ & $\begin{array}{l}\text { Somewhat } \\
\text { disagree }\end{array}$ & $\begin{array}{l}\text { Neither agree } \\
\text { nor disagree }\end{array}$ & $\begin{array}{l}\text { Somewhat } \\
\text { agree }\end{array}$ & $\begin{array}{l}\text { Strongly } \\
\text { agree }\end{array}$ \\
\hline & $\begin{array}{l}\text { Strongly } \\
\text { disagree }\end{array}$ & $\begin{array}{l}\text { Somewhat } \\
\text { disagree }\end{array}$ & $\begin{array}{l}\text { Neither agree } \\
\text { nor disagree }\end{array}$ & $\begin{array}{l}\text { Somewhat } \\
\text { agree }\end{array}$ & $\begin{array}{c}\text { Strongly } \\
\text { agree }\end{array}$ \\
\hline Recreation & $\mathrm{O}$ & $\mathrm{O}$ & $\mathrm{O}$ & $\mathrm{O}$ & $\mathrm{O}$ \\
\hline $\begin{array}{l}\text { Experiencing Friendly } \\
\text { Service }\end{array}$ & $\mathrm{O}$ & $\bigcirc$ & $\bigcirc$ & $\bigcirc$ & $\bigcirc$ \\
\hline Learning about WVU & $\mathrm{O}$ & O & O & O & O \\
\hline Enjoying the outdoors & $\mathrm{O}$ & O & O & $\bigcirc$ & $\mathrm{O}$ \\
\hline Seeing Scenic Beauty & $\mathrm{O}$ & O & O & $\bigcirc$ & $\mathrm{O}$ \\
\hline Gaining Knowledge & $\mathrm{O}$ & $\mathrm{O}$ & $\mathrm{O}$ & $\mathrm{O}$ & $\mathrm{O}$ \\
\hline Having fun & $\mathrm{O}$ & $\bigcirc$ & $\bigcirc$ & $\bigcirc$ & $\bigcirc$ \\
\hline \multirow[t]{2}{*}{ Having Large Groups } & 0 & $\mathrm{O}$ & $\mathrm{O}$ & $\mathrm{O}$ & $\mathrm{O}$ \\
\hline & $\begin{array}{l}\text { Strongly } \\
\text { disagree }\end{array}$ & $\begin{array}{l}\text { Somewhat } \\
\text { disagree }\end{array}$ & $\begin{array}{l}\text { Neither agree } \\
\text { nor disagree }\end{array}$ & $\begin{array}{l}\text { Somewhat } \\
\text { agree }\end{array}$ & $\begin{array}{l}\text { Strongly } \\
\text { agree }\end{array}$ \\
\hline To Create Meaning & $\mathrm{O}$ & $\mathrm{O}$ & $\mathrm{O}$ & O & 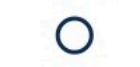 \\
\hline Exciting Experience & $\mathrm{O}$ & $\bigcirc$ & $\bigcirc$ & O & O \\
\hline $\begin{array}{l}\text { Participating in Safe } \\
\text { Activities }\end{array}$ & $\mathrm{O}$ & $\bigcirc$ & O & O & O \\
\hline $\begin{array}{l}\text { Experiencing Mental } \\
\text { Growth }\end{array}$ & $\mathrm{O}$ & $\bigcirc$ & O & O & O \\
\hline $\begin{array}{l}\text { Experiencing } \\
\text { Punctuality }\end{array}$ & $\mathrm{O}$ & $\bigcirc$ & $\bigcirc$ & $\bigcirc$ & $\mathrm{O}$ \\
\hline $\begin{array}{l}\text { Gaining a new } \\
\text { experience }\end{array}$ & $\mathrm{O}$ & $\bigcirc$ & $\bigcirc$ & $\bigcirc$ & $\mathrm{O}$ \\
\hline $\begin{array}{l}\text { Experiencing } \\
\text { Professionalism }\end{array}$ & $\mathrm{O}$ & $\bigcirc$ & $\bigcirc$ & $\bigcirc$ & $\bigcirc$ \\
\hline \multirow[t]{2}{*}{$\begin{array}{l}\text { Experiencing Physical } \\
\text { Growth }\end{array}$} & $\mathrm{O}$ & $\bigcirc$ & $\bigcirc$ & $\mathrm{O}$ & $\mathrm{O}$ \\
\hline & $\begin{array}{l}\text { Strongly } \\
\text { disagree }\end{array}$ & $\begin{array}{l}\text { Somewhat } \\
\text { disagree }\end{array}$ & $\begin{array}{l}\text { Neither agree } \\
\text { nor disagree }\end{array}$ & $\begin{array}{l}\text { Somewhat } \\
\text { agree }\end{array}$ & $\begin{array}{c}\text { Strongly } \\
\text { agree }\end{array}$ \\
\hline Making memories & $\mathrm{O}$ & $\bigcirc$ & O & $\bigcirc$ & $\mathrm{O}$ \\
\hline $\begin{array}{l}\text { Having a Controlled } \\
\text { Environment }\end{array}$ & $\mathrm{O}$ & $\mathrm{O}$ & $\mathrm{O}$ & $\mathrm{O}$ & $\mathrm{O}$ \\
\hline Feeling Pressure & $\mathrm{O}$ & O & O & O & O \\
\hline Enjoying new activities & $\mathrm{O}$ & $\bigcirc$ & $\bigcirc$ & $\mathrm{O}$ & $\mathrm{O}$ \\
\hline Having Small groups & $\mathrm{O}$ & O & O & O & O \\
\hline Deepening Relationship & $\mathrm{O}$ & $\mathrm{O}$ & $\bigcirc$ & $\mathrm{O}$ & $\bigcirc$ \\
\hline
\end{tabular}

\section{Section 4}




\section{Section IV: Satisfaction of Today's OEC Experience}

Listed below are phrases about satisfactions with various part of your experience today. Please indicate how much you agree with each statement by choosing your response.

\section{Overall:}

$\begin{array}{lcccc}\begin{array}{l}\text { Strongly } \\ \text { disagree }\end{array} & \begin{array}{c}\text { Somewhat } \\ \text { disagree }\end{array} & \begin{array}{c}\text { Neither agree } \\ \text { nor disagree }\end{array} & \begin{array}{c}\text { Somewhat } \\ \text { agree }\end{array} & \begin{array}{c}\text { Strongly } \\ \text { agree }\end{array}\end{array}$

I enjoyed my visit to the Outdoor Education Center

O $\quad 0$

$\mathrm{O}$

Settings:

The site was well maintained/managed

$\begin{array}{lcccc}\begin{array}{c}\text { Strongly } \\ \text { disagree }\end{array} & \begin{array}{c}\text { Somewhat } \\ \text { disagree }\end{array} & \begin{array}{c}\text { Neither agree } \\ \text { nor disagree }\end{array} & \begin{array}{c}\text { Somewhat } \\ \text { agree }\end{array} & \begin{array}{c}\text { Strongly } \\ \text { agree }\end{array}\end{array}$

The setting was logical for my experience

There was adequate signage for my arrival

$\begin{array}{cccc}0 & 0 & 0 & 0 \\ 0 & 0 & 0 & 0 \\ 0 & 0 & 0 & 0 \\ 0 & 0 & 0 & 0 \\ 0 & 0 & 0 & 0 \\ 0 & 0 & 0 & 0\end{array}$

$\mathrm{O}$ I was pleased with my first impression of the area

The setting was beneficial for my experience

The Setting of the Outdoor Education Center was acceptable

Facilities:

$\begin{array}{lcccc}\begin{array}{c}\text { Strongly } \\ \text { disagree }\end{array} & \begin{array}{c}\text { Somewhat } \\ \text { disagree }\end{array} & \begin{array}{c}\text { Neither agree } \\ \text { nor disagree }\end{array} & \begin{array}{c}\text { Somewhat } \\ \text { agree }\end{array} & \begin{array}{c}\text { Strongly } \\ \text { agree }\end{array}\end{array}$

The facility was operational

$\bigcirc \quad \bigcirc$

O 


\begin{tabular}{|c|c|c|c|c|c|}
\hline & $\begin{array}{l}\text { Strongly } \\
\text { disagree }\end{array}$ & $\begin{array}{l}\text { Somewhat } \\
\text { disagree }\end{array}$ & $\begin{array}{c}\text { Neither agree } \\
\text { nor disagree }\end{array}$ & $\begin{array}{l}\text { Somewhat } \\
\text { agree }\end{array}$ & $\begin{array}{c}\text { Strongly } \\
\text { agree }\end{array}$ \\
\hline $\begin{array}{l}\text { I was comfortable } \\
\text { during my time at the } \\
\text { OEC }\end{array}$ & $\mathrm{O}$ & $\mathrm{O}$ & $\bigcirc$ & $\bigcirc$ & $\mathrm{O}$ \\
\hline $\begin{array}{l}\text { I am satisfied with my } \\
\text { access to basic needs }\end{array}$ & $\mathrm{O}$ & $\mathrm{O}$ & $\mathrm{O}$ & $\mathrm{O}$ & $\mathrm{O}$ \\
\hline I felt safe at the facility & $\mathrm{O}$ & $\mathrm{O}$ & $\mathrm{O}$ & $\mathrm{O}$ & $\mathrm{O}$ \\
\hline $\begin{array}{l}\text { The facility was a key } \\
\text { part of my experience }\end{array}$ & $\mathrm{O}$ & $\mathrm{O}$ & O & O & 0 \\
\hline
\end{tabular}

Which activity did you participate in?

Canopy Tour

Activity:

My program was worth the cost

My program was challenging

I was prepared during my program

My activity was overall satisfying

My needs were met during the program
Challenge Course

\section{Staffing:}

$\begin{array}{ccccc}\begin{array}{c}\text { Strongly } \\ \text { disagree }\end{array} & \begin{array}{c}\text { Somewhat } \\ \text { disagree }\end{array} & \begin{array}{c}\text { Neither agree } \\ \text { nor disagree }\end{array} & \begin{array}{c}\text { Somewhat } \\ \text { agree }\end{array} & \begin{array}{c}\text { Strongly } \\ \text { agree }\end{array} \\ 0 & 0 & 0 & 0 & 0 \\ 0 & 0 & 0 & 0 & 0 \\ 0 & 0 & 0 & 0 & 0 \\ 0 & 0 & 0 & 0 & 0 \\ 0 & 0 & 0 & 0 & 0\end{array}$

The staff was attentive

$\begin{array}{lcccc}\text { Strongly } & \text { Somewhat } \\ \text { disagree } & \text { disagree } & \begin{array}{c}\text { Neither agree } \\ \text { nor disagree }\end{array} & \begin{array}{c}\text { Somewhat } \\ \text { agree }\end{array} & \begin{array}{c}\text { Strongly } \\ \text { agree }\end{array}\end{array}$

My facilitators were a satisfying part of my experience

The staff gave good instructions

O

O

O

$\mathrm{O}$

O

The staff was helpful 


\begin{tabular}{|c|c|c|c|c|c|}
\hline & $\begin{array}{l}\text { Strongly } \\
\text { disagree }\end{array}$ & $\begin{array}{l}\text { Somewhat } \\
\text { disagree }\end{array}$ & $\begin{array}{l}\text { Neither agree } \\
\text { nor disagree }\end{array}$ & $\begin{array}{l}\text { Somewhat } \\
\text { agree }\end{array}$ & $\begin{array}{c}\text { Strongly } \\
\text { agree }\end{array}$ \\
\hline $\begin{array}{l}\text { The staff stayed } \\
\text { positive }\end{array}$ & $\mathrm{O}$ & $\bigcirc$ & $\bigcirc$ & $\bigcirc$ & $\mathrm{O}$ \\
\hline $\begin{array}{l}\text { The staff was } \\
\text { appropriate }\end{array}$ & $\mathrm{O}$ & 0 & O & O & 0 \\
\hline $\begin{array}{l}\text { The staff was } \\
\text { knowledgeable }\end{array}$ & $\mathrm{O}$ & O & $\bigcirc$ & $\bigcirc$ & 0 \\
\hline \multicolumn{6}{|l|}{ Pre/Post Programming: } \\
\hline & $\begin{array}{l}\text { Strongly } \\
\text { disagree }\end{array}$ & $\begin{array}{l}\text { Somewhat } \\
\text { disagree }\end{array}$ & $\begin{array}{l}\text { Neither agree } \\
\text { nor disagree }\end{array}$ & $\begin{array}{l}\text { Somewhat } \\
\text { agree }\end{array}$ & $\begin{array}{c}\text { Strongly } \\
\text { agree }\end{array}$ \\
\hline Billing was easy & $\mathrm{O}$ & $\mathrm{O}$ & $\mathrm{O}$ & 0 & $\mathrm{O}$ \\
\hline $\begin{array}{l}\text { The pre/post } \\
\text { programming logistics } \\
\text { were handled well }\end{array}$ & $\mathrm{O}$ & $\mathrm{O}$ & $\bigcirc$ & $\mathrm{O}$ & $\mathrm{O}$ \\
\hline $\begin{array}{l}\text { The management team } \\
\text { was easy to talk to }\end{array}$ & $\bigcirc$ & $\bigcirc$ & $\bigcirc$ & $\bigcirc$ & $\bigcirc$ \\
\hline $\begin{array}{l}\text { Scheduling was } \\
\text { adequate }\end{array}$ & $\bigcirc$ & $\bigcirc$ & $\mathrm{O}$ & $\bigcirc$ & $\bigcirc$ \\
\hline $\begin{array}{l}\text { During this time, the } \\
\text { staff was } \\
\text { accommodating }\end{array}$ & $\mathrm{O}$ & $\bigcirc$ & $\bigcirc$ & $\bigcirc$ & $\mathrm{O}$ \\
\hline $\begin{array}{l}\text { I was prepared for my } \\
\text { program. }\end{array}$ & $\mathrm{O}$ & $\bigcirc$ & $\bigcirc$ & $\bigcirc$ & $\bigcirc$ \\
\hline
\end{tabular}

\section{Return Visitation:}

\begin{tabular}{|c|c|c|c|c|c|}
\hline & $\begin{array}{l}\text { Strongly } \\
\text { disagree }\end{array}$ & $\begin{array}{c}\text { Somewhat } \\
\text { disagree }\end{array}$ & $\begin{array}{l}\text { Neither agree } \\
\text { nor disagree }\end{array}$ & $\begin{array}{l}\text { Somewhat } \\
\text { agree }\end{array}$ & $\begin{array}{c}\text { Strongly } \\
\text { agree }\end{array}$ \\
\hline $\begin{array}{l}\text { I would visit this place } \\
\text { again. }\end{array}$ & 0 & 0 & 0 & 0 & 0 \\
\hline $\begin{array}{l}\text { I would tell other } \\
\text { people positive things } \\
\text { about this place. }\end{array}$ & 0 & 0 & 0 & 0 & 0 \\
\hline $\begin{array}{l}\text { I would recommend } \\
\text { this place to people } \\
\text { who seek my advice. }\end{array}$ & 0 & 0 & 0 & 0 & 0 \\
\hline $\begin{array}{l}\text { I would recommend } \\
\text { this place to my } \\
\text { friends. }\end{array}$ & 0 & 0 & 0 & 0 & 0 \\
\hline
\end{tabular}




\section{Section 5}

\section{Section V: Background Information}

Gender (Choose the most appropriate answer)
Male
Female

Age (Please check the single best answer)

$\bigcirc$ Under 18

O 18 - 24

O 25 - 34

O $35-44$

O 45 - 54

O $55-64$

O $65-74$

O $75-84$

85 or older

What is the highest level of education you have completed? (Please check the single best answer)

Less than high school

$\bigcirc$ High school graduate

Some college

2 year degree

$\bigcirc 4$ year degree

$\bigcirc$ Professional degree

Doctorate

Were you the group organizer?

$\bigcirc$ Yes 
No

How would you describe your group?

$\begin{array}{lccccc}\text { Group Information } & \text { Single } & \text { Couple } & \text { Friend Group } & \text { School Group } & \text { Club } \\ & \bigcirc & \bigcirc & \bigcirc & \bigcirc & \bigcirc \\ \text { Group Affiliation } & \text { WvU Student } & \text { wVU Staff } & \text { wVU Faculty } & \text { Non Profit } & \text { General Public } \\ & \bigcirc & \bigcirc & \bigcirc & \bigcirc & \bigcirc\end{array}$

How many people were in your group?

Less than 10

11-30

$31-50$

More Than 50

Where are you from?

Community/ Town Name

State

Postal Code

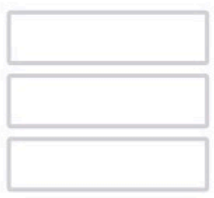

Do have any additional comments that were not mentioned in this survey? If so, please specify below.

Indicate your full name and contact information if you are interested in 1 of 2 prizes. 